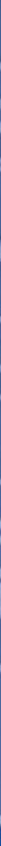

\title{
WOMEN'S WRITING FROM WALES BEFORE 1914
}

Edited by

Jane Aaron

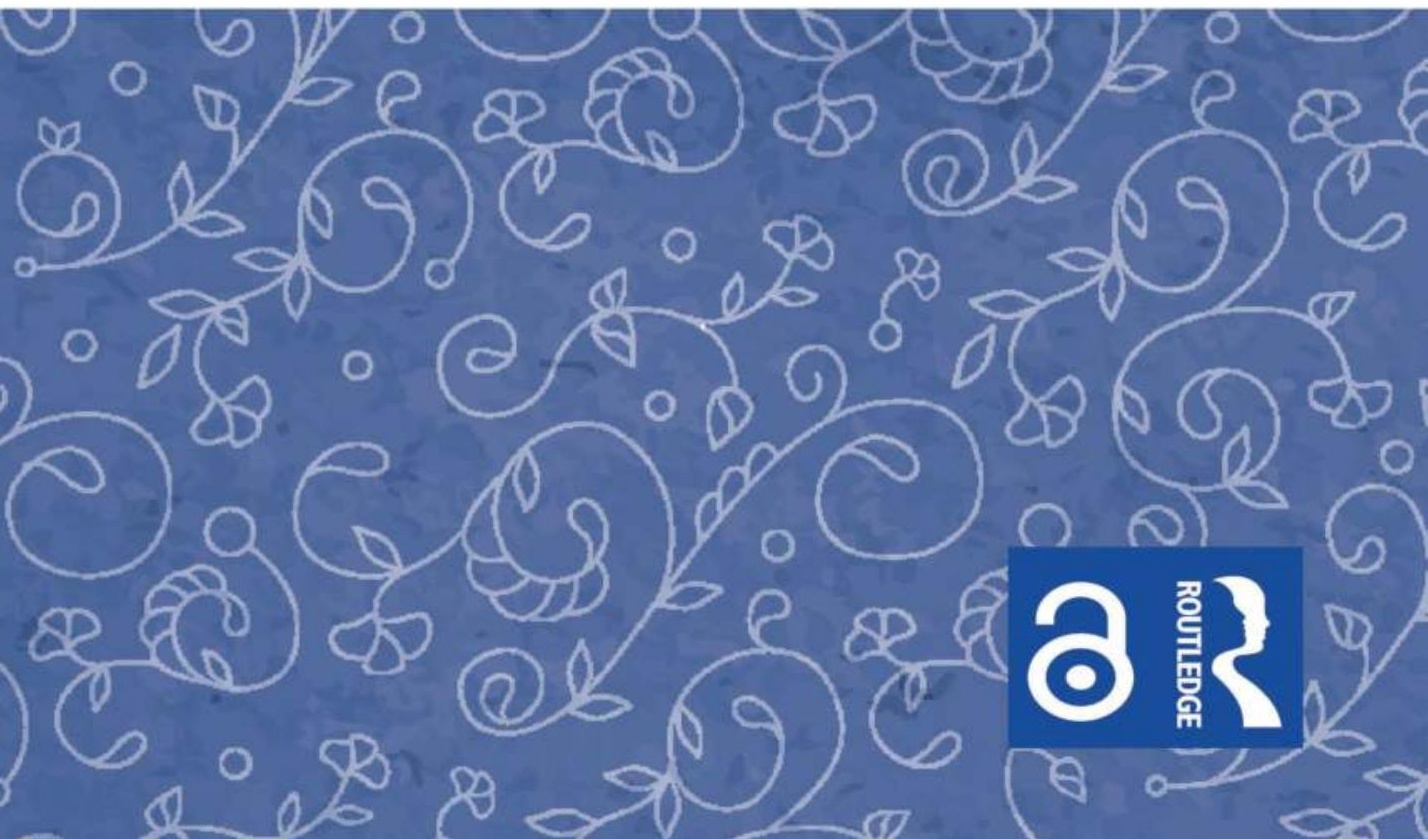




\section{Women's Writing from Wales before 1914}

This essay collection rediscovers and reassesses a host of still little-known, pre-1914, Welsh women writers.

In the last few decades considerable advances have been made towards rediscovering, contextualising, and analysing women's writing from Wales. The combined influences of the post-1960s women's movement, the 1990s Welsh devolution successes, and the development of the 'Four Nations' school of British literary criticism, have together effected significant advances in the field of Welsh feminist literary studies. This book focuses in particular on: the fifteenth- to eighteenth-century Welsh-language bards, such as Gwerful Mechain, Angharad James, and Marged Dafydd; the seventeenth- and eighteenth-century English-language poets, including Katherine Philips, Jane Brereton, Anne Penny, and Anne Hughes; contributors to the Romantic movement in Wales, such as the poets and novelists Mary Robinson and Ann of Swansea; the mid-nineteenth-century protesting voice of polemicists such as Jane Williams (Ysgafell); the Victorian Englishlanguage novelists, for example Louisa Matilda Spooner, Anne Beale, Amy Dillwyn, Allen Raine, and Mallt Williams, and their concern with national, class, and gender identities; and early twentieth-century Welsh-language writers engaged with Welsh Home Rule and women's suffrage issues, such as Gwyneth Vaughan and Eluned Morgan.

This book was originally published as a special issue of Women's Writing. Chapter 7 is available Open Access at https://www.routledge.com/products/ 9780367353483.

Jane Aaron is Emeritus Professor at the University of South Wales, UK. Her publications include A Double Singleness: Gender and the Writings of Charles and Mary Lamb (1991), Pur fel y Dur: Y Gymraes yn Llên Menywod y Bedwaredd Ganrif ar Bymtheg [Pure as Steel: The Welsh Woman in 19th Century Women's Literature] (1998), Nineteenth-Century Women's Writing in Wales (2007), and Welsh Gothic (2013). She is also the general editor of Honno Press's Welsh Women's Classics series. 


\section{Historical Women's Writing}

Series editor:

Marie Mulvey-Roberts, Professor of English Literature at the University of the

West of England, Bristol, UK

This series explores a wide range of women's writing from across the world, spanning several centuries up to the First World War. Each volume consists of a collection of essays focusing on a specific theme, time-period, genre, or author, ranging from the canonical to lesser-known and neglected writers. These books will be a valuable resource for scholars and students of literature and history, as well as for more general readers with an interest in historical women writers and their work.

Recent titles in the series include:

Katherine Philips: Form, Reception, and Literary Contexts

Edited by Marie-Louise Coolahan and Gillian Wright

Women's Writing of the First World War

Edited by Emma Liggins and Elizabeth Nolan

Mary Hays's 'Female Biography'

Collective Biography as Enlightenment Feminism

Edited by Mary Spongberg and Gina Luria Walker

Suffrage and Women's Writing

Edited by June Hannam and Katherine Holden

Women's Writing from Wales before 1914

Edited by Jane Aaron

Children's Literature in the Long 19th Century

Edited by Catherine Butler and Ann Alston

Bicentennial Essays on Jane Austen's Afterlives

Edited by Annika Bautz and Sarah Wootton

\section{Locating Ann Radcliffe}

Edited by Andrew Smith and Mark Bennett

For a full list of titles please visit

https://www.routledge.com/Historical-Womens-Writing/book-series/HWW 


\title{
Women's Writing from \\ Wales before 1914
}

\author{
Edited by
}

Jane Aaron 
First published 2020

by Routledge

2 Park Square, Milton Park, Abingdon, Oxon, OX14 4RN

and by Routledge

52 Vanderbilt Avenue, New York, NY 10017

Routledge is an imprint of the Taylor \& Francis Group, an informa business

Introduction, Chapters 1-6, 8 @ 2020 Taylor \& Francis

Chapter 7 (c) 2016 Kirsti Bohata and Alexandra Jones. Originally

published as Open Access.

With the exception of Chapter 7, no part of this book may be reprinted or reproduced or utilised in any form or by any electronic, mechanical, or other means, now known or hereafter invented, including photocopying and recording, or in any information storage or retrieval system, without permission in writing from the publishers. For details on the rights for Chapter 7, please see the chapter's Open Access footnote. Chapter 7 of this book is available for free in PDF format as Open Access from the individual product page at www.routledge.com. It has been made available under a Creative Commons Attribution 4.0 license.

Trademark notice: Product or corporate names may be trademarks or registered trademarks, and are used only for identification and explanation without intent to infringe.

British Library Cataloguing in Publication Data

A catalogue record for this book is available from the British Library

ISBN 13: 978-0-367-35348-3

Typeset in Minion Pro

by RefineCatch Limited, Bungay, Suffolk

\section{Publisher's Note}

The publisher accepts responsibility for any inconsistencies that may have arisen during the conversion of this book from journal articles to book chapters, namely the inclusion of journal terminology.

\section{Disclaimer}

Every effort has been made to contact copyright holders for their permission to reprint material in this book. The publishers would be grateful to hear from any copyright holder who is not here acknowledged and will undertake to rectify any errors or omissions in future editions of this book. 


\section{Contents}

Citation Information vii

Notes on Contributors $\quad$ ix

Introduction $\quad 1$

Jane Aaron

1. Problems of Authorship and Attribution: The Welsh-language

Women's Canon Before 1800

Cathryn A. Charnell-White

2. Cambrian Bards and Antiquarian Romantics: Anglophone

Women Poets from Eighteenth-Century Wales

Sarah Prescott

3. "Local and Contemporary": Reception, Community and the

Poetry of Ann Julia Hatton ("Ann of Swansea")

Elizabeth Edwards

4. "At Once Illogical and Unfair": Jane Williams (Ysgafell) and the Government Report on Education in Mid Nineteenth-Century Wales Gwyneth Tyson Roberts

5. Adapting the Risorgimento: Ideas of Liberal Nationhood in

L. M. Spooner's Country Landlords (1860)

Rita Singer

6. "Our Poor Land of Wales": National Identity and National Heroism in Women's Historical Fictions

Diana Wallace

7. Welsh Women's Industrial Fiction 1880-1910

Kirsti Bohata and Alexandra Jones

8. Gwyneth Vaughan, Eluned Morgan and the Emancipation of Welsh Women

Rosanne Reeves and Jane Aaron

Index 
$\Rightarrow$ Taylor \& Francis

Taylor \& Francis Group

http://taylorandfrancis.com 


\section{Citation Information}

The chapters in this book were originally published in Women's Writing, volume 24, issue 4 (November 2017). When citing this material, please use the original page numbering for each article, as follows:

\section{Introduction}

Introduction

Jane Aaron

Women's Writing, volume 24, issue 4 (November 2017), pp. 389-397

\section{Chapter 1}

Problems of Authorship and Attribution: The Welsh-language Women's Canon Before 1800

Cathryn A. Charnell-White

Women's Writing, volume 24, issue 4 (November 2017), pp. 398-417

\section{Chapter 2}

Cambrian Bards and Antiquarian Romantics: Anglophone Women Poets from Eighteenth-Century Wales

Sarah Prescott

Women's Writing, volume 24, issue 4 (November 2017), pp. 418-435

\section{Chapter 3}

"Local and Contemporary": Reception, Community and the Poetry of Ann Julia Hatton ("Ann of Swansea")

Elizabeth Edwards

Women's Writing, volume 24, issue 4 (November 2017), pp. 436-450

\section{Chapter 4}

"At Once Illogical and Unfair": Jane Williams (Ysgafell) and the Government Report on Education in Mid Nineteenth-Century Wales Gwyneth Tyson Roberts

Women's Writing, volume 24, issue 4 (November 2017), pp. 451-465 


\section{Chapter 5}

Adapting the Risorgimento: Ideas of Liberal Nationhood in L. M. Spooner's

Country Landlords (1860)

Rita Singer

Women's Writing, volume 24, issue 4 (November 2017), pp. 466-481

\section{Chapter 6}

"Our Poor Land of Wales": National Identity and National Heroism in Women's Historical Fictions

Diana Wallace

Women's Writing, volume 24, issue 4 (November 2017), pp. 482-498

\section{Chapter 7}

Welsh Women's Industrial Fiction 1880-1910

Kirsti Bohata and Alexandra Jones

Women's Writing, volume 24, issue 4 (November 2017), pp. 499-516

\section{Chapter 8}

Gwyneth Vaughan, Eluned Morgan and the Emancipation of Welsh Women Rosanne Reeves and Jane Aaron

Women's Writing, volume 24, issue 4 (November 2017), pp. 517-534

For any permission-related enquiries please visit:

http://www.tandfonline.com/page/help/permissions 


\section{Notes on Contributors}

Jane Aaron is Emeritus Professor at the University of South Wales, UK. She is also the general editor of Honno Press's Welsh Women's Classics series.

Kirsti Bohata is Professor of English Literature and Creative Writing and Director of the Centre for Research into the English Literature and Language of Wales at Swansea University, UK.

Cathryn A. Charnell-White is a Senior Lecturer and Head of the Department of Welsh and Celtic Studies at Aberystwyth University, UK.

Elizabeth Edwards is a Research Fellow at the University of Wales Centre for Advanced Welsh and Celtic Studies in Aberystwyth, UK.

Alexandra Jones completed her $\mathrm{PhD}$ at the Centre for Research into the English Literature and Language of Wales at Swansea University, UK.

Sarah Prescott is a Professor and the Principal of the College of Arts and Humanities at University College Dublin, Ireland.

Rosanne Reeves is a founder and continuing board member of the Welsh feminist press Honno (1986-). She is joint editor of Honno Press's Welsh language Classics series.

Rita Singer is an Honorary Research Fellow in the School of Languages, Literatures and Linguistics at Bangor University, UK.

Gwyneth Tyson Roberts has taught and lectured in Baghdad, Lisbon, London, and Aberystwyth.

Diana Wallace is Professor of English Literature at the University of South Wales, UK. 
$\Rightarrow$ Taylor \& Francis

Taylor \& Francis Group

http://taylorandfrancis.com 


\section{INTRODUCTION}

In the opening years of the twenty-first century, a newly devolved Wales surprised commentators by becoming the first nation to achieve gender equality in political representation. “At last!” reported the Guardian on 9 May 2003: "In the 60-strong Welsh Assembly, there are 30 men and 30 women. Parity! And in Wales of all places". The Guardian's surprise is understandable given the fact that throughout the twentieth century few women had represented Wales in Westminster; only one-tenth of Welsh Members of Parliament were female in the early 1990s. But in 1999, when the first Welsh National Assembly was elected, 40\% of its members were female, and in 2000 women made up the majority of its cabinet ministers. ${ }^{2}$ Interestingly, a similar post-devolution move towards gender parity has also occurred with regard to Wales's literary representatives; since 1999, female authors, writing in both of Wales's languages, have gained recognition on a hitherto unprecedented scale. Since the post of Welsh National Poet was created in 2005, two out of its four successive holders to date have been women (Gwyneth Lewis and Gillian Clarke); in 2013, the Welsh National Eisteddfod for the first time since its revival in the 1860s appointed a female Archdruid (Christine James); and the ratio of women to men winning the country's main literary prizes has been much higher since 1999 than it was throughout the twentieth century, and approaches parity. ${ }^{3}$ For all the valiant attempts of many of its female members, the Assembly has not as yet succeeded in doing much to amend the continuing economic disparities between men and women in Wales, ${ }^{4}$ yet its creation has led to much greater gender equality in terms of both political and cultural representation. A hitherto submerged nation emerges more into view post-devolution; it acquires greater representational space, and Welsh women have availed themselves of that expanded opportunity.

The fact that the journal Women's Writing has seen fit to dedicate this special issue to writers from Wales is but one indication of a similar post-devolution increase in critical studies of Welsh women's writing. Although recognition of this literary field remains erratic, in comparison to earlier periods considerable strides have been made in the last few decades towards rediscovering, contextualizing, analysing and teaching women's writing from Wales. Recollecting her upbringing in Cardiff in the middle years of the twentieth century, Gillian Clarke remembers that, throughout her school and university years, "[f]ormal education offered only poetry by men, and all of them English [...] As a Welsh girl I had no poet-heroines to follow". ${ }^{5}$ Had she been granted the opportunity to study through the medium of Welsh, she would not necessarily have fared much better with regard to female role models. When, in 1986, four critics collaborated on the production of a groundbreaking special issue on women's writing for the journal Y Traethodydd, they noted the fact that the school A level syllabus for Welsh literature in that year included only one female poet, the hymn-writer 
Ann Griffiths (1776-1805). ${ }^{6}$ But, by 1986, women informed by the second wave of the feminist movement were effecting changes. The independent Welsh feminist press Honno was also established in that year, by a women's collective aiming to "increase the opportunities for Welsh women in publishing and bring Welsh women's literature to a wider public". ${ }^{7}$ As well as publishing contemporary new titles, Honno (i.e. "That Female One") also publishes editions of previously neglected and out-of-print Welsh women's classics in both Welsh and English. Such enterprises have had their effect on educational syllabuses. Whereas in 1989 the only Welsh woman writer taught in Aberystwyth University's English literature syllabus was the Welsh-language novelist Kate Roberts, taught in translation, ${ }^{8}$ in 2010 undergraduate Welsh writing in English modules taught 16 women authors compared to 20 male ones, and in 2013 that ratio was 33 women to 44 men. Published research in the field has also been marked by a similar shift. In the mid 1990s, records indicate that, annually, the ratio of critical studies on Welsh anglophone women authors in relation to men was less than 1:10; by the late 2000s, however, gender parity was much improved in this context too, with 22 women to 45 men featuring as the subject of critical studies in 2009, along with 24 works comparing texts by both sexes. ${ }^{9}$

While this ongoing quiet revolution within Welsh literary studies may not have achieved much recognition beyond Wales's borders, the development since the 1980s of the so-called "archipelagic" school of literary criticism, with its emphasis on the importance of including in British cultural studies the literature of all four of the United Kingdom's nations, has helped to further international awareness of Welsh writing. Intent on rebalancing the "casual anglocentricity" of much literary scholarship, as Kate Chedgzoy puts it in her Women's Writing in the British Atlantic World: Memory, Place and History $1550-1700$ (2007), a work which includes a strong Welsh dimension, ${ }^{10}$ the "Four Nations" school has also had its effects on feminist scholarship. The various volumes of Palgrave Macmillan's recently published History of British Women's Writing, for example, usually - though not invariably-include informative material on Welsh women's writing. "Four Nations" criticism can, however, sometimes in practice feature only three nations: Stephen Behrendt's British Women Poets and the Romantic Writing Community (2009), for example, allots a chapter each to Scottish and Irish women poets, but makes no reference to the numerous women who wrote anglophone poetry in Wales during the Romantic period. ${ }^{11}$ Or, rather, it does refer amply enough to some poets with marked Welsh connections-to Felicia Hemans and Mary Robinson, for example-but makes no mention of the fact that they were writing from Wales or including Welsh themes in their oeuvre. ${ }^{12}$ In Behrendt's defence, however, it must be acknowledged that, until very recently, such omissions were commonplace: Hemans or, in a seventeenth-century context, Katherine Philips ("Orinda") might be critically hailed as amongst the best-known women poets of their respective eras, but studies of their work, penned outside Wales, characteristically paid little or no attention to the specificities of the location in which it was produced. The focus on location in archipelagic studies is currently working 
to correct such a bias, however, and international scholarship is now interesting itself in the complex self-positioning of such writers as Hemans and Philips, neither of them Welsh by birth but, of course, affected by, and affecting, the Welsh contexts in which they lived and wrote. ${ }^{13}$

Much work remains to be done, however, in the rediscovery and reassessment of a host of still little-known Welsh women writers. It is the aim of this present collection to continue explorations in the field by filling a few further gaps in our current knowledge of women's contribution to Welsh and anglophone Welsh writing before 1914. Given the length of the time span covered by the contributions to this special issue, it may prove helpful to readers unfamiliar with the specificities of Welsh history if, in introducing the articles which follow, some attempt is made to set them in their historical context. Accordingly, the rest of this introduction provides a necessarily brief historical contextualization of women's lives in Wales from the Welsh Act of Union to the onset of the First World War, drawing attention to those key events which furthered, or restricted, their development.

\section{Female bards and the Celtic Revival}

Until the last few decades of the time span covered by this special issue, by far the most distinctive marker of Welsh difference was the Welsh language. At the time of Wales's formal unification with England in 1536, the mass of the population living to the west of Offa's Dyke were monoglot Welsh speakers; in 1891, the first Welsh census to survey language use recorded that $54.5 \%$ of the population spoke Welsh, and $30.4 \%$ were still monoglot in that language. ${ }^{14}$ Before the formation of such national institutions as the University of Wales in 1893, and the National Museum and National Library of Wales in 1907, other universally acknowledged markers of Welsh national difference were scarce. Even the last indigenous Prince of Wales, Llywelyn ap Gruffudd-the first ruler to be recognized by England, in 1267, as authorized to represent Wales as a whole-only had authority over west Wales, the eastern half of the country and Pembrokeshire being then under the rule of the Marcher Anglo-Norman lords. After Llywelyn was killed in 1282 during the Plantagenet conquest of Wales, little was left to mark Welsh difference apart from the language and its culture, which was predominantly bardic. During the early modern period, the boundaries of ethnic difference were further complicated by the Welsh propensity to view the Cymry (the people of Wales) as the only true Britons-descendants of the native inhabitants of Roman Britain before the Saxon and Norman invasions. Accordingly, when Henry Tudor, of Welsh blood, took the English throne in 1485, he was valorized by the Welsh bards as the mab darogan ("son of prophecy"), the fulfilment of the ancient dream that one day true Britons would regain control of the isle. His ascension was particularly welcomed because it followed the defeat of a previous mab darogan, the freedom fighter Owain Glyndwir, and the collapse of his 140014 warfaring campaign to restore Welsh independence. ${ }^{15}$ In the attempt to control and punish Welsh rebelliousness, a new penal code was imposed on Wales by the English Parliament in 1402, which prevented the Welsh from 
holding public office and debarred them from residence within the walls of Wales's castellated boroughs. Englishmen and Englishwomen married to Welsh spouses were subject to the same penalties, although the more affluent Welsh gentry could buy their way out of these humiliations by purchasing "letters of denizenship" declaring them to be English. ${ }^{16}$ The turbulence of fifteenthcentury Wales later captured the imagination of a number of Victorian women writing historical fictions, as Diana Wallace illustrates in her contribution to this special issue.

In the event, however, the Tudor ascension only speeded up the anglicization of Wales. The so-called Welsh Act of Union, drawn up by Thomas Cromwell for Henry Tudor's son Henry VIII in a series of measures put through from 1536 to 1543 , states that "minding and intending to reduce them [i.e. the Welsh] to perfect order, notice and knowledge of his laws [...] and utterly to extirpate all the singular sinister uses and customs differing from the same", the king formally "annexed" Wales "to and with this realm of England", restoring civic rights to the Welsh with the proviso that "from henceforth no person or persons that use Welsh speech or language shall have or enjoy any manner of office or fees $[\ldots]$ unless he or they use and exercise the speech or language of English" ${ }^{17}$ English remained the only official language of Wales - the only language that could be used in its law courts-until the Welsh Language Act of 1967. Consequently, those members of the upper scions of Welsh society who had not earlier followed Henry VII to London now rapidly succumbed to anglicization. Although the mass of the population remained Welsh-speaking, the gentry's language shift had a particularly deleterious effect on the Welsh-language bardic culture, which had relied on the patronage of the nobility. It was within this now waning culture that the names of Welsh women writers first emerged from obscurity, albeit tentatively in many cases. Although the traditional role of the bard, employed as a member of a prince's or lord's retinue to sing his praises, meant that his profession was considered an unsuitable one for a woman, certain women of privilege did succeed in participating as amateurs within it. By today, considerable scholarly energy has been devoted to the task of identifying, analysing and editing the work of these early women poets. Cathryn Charnell-White details the critical heritage in her contribution to this issue, in which she examines the difficulties of constructing a historically attested canon of women's writing when working with the fragmentary evidence provided by oral and manuscript poetry transmission. In particular, she argues that the understandable propensity of the modern feminist critic to see these poets as participating in a specifically female tradition, influenced by their foremothers and sister poets, has not as yet been validated by the available historical documentation.

The survival into modern times of the language in which these women composed is generally attributed to the fact that Henry VIII's break with the Roman Catholic Church, and the resultant need to make Britain Protestant, necessitated the production in 1588, during his daughter Elizabeth's reign, of a Welshlanguage translation of the Bible, for use instead of the Latin Bible within Protestant worship in a still largely monoglot Welsh-speaking Wales. Welsh thus became sanctioned as a language of religion and it flourished, in particular, 
within Nonconformist religious circles. During the Civil War, Wales was torn, like England, between Roundhead and Cavalier sympathies, which sometimes even divided families: Katherine Philips was a Royalist while her husband, James Philips of Cardigan Priory, was one of the leaders of the parliamentarian cause in west Wales. ${ }^{18}$ But in later years, particularly after the Methodist Revival of the mid eighteenth century, Nonconformist religion became the lodestone of Welsh-language culture, with women as well as men contributing to its canon of hymns and poetry. ${ }^{19}$

The mid eighteenth century also marked the onset of Welsh involvement in a Celtic Revival, spurred into activity by the popularity of both Thomas Gray's "The Bard" (1757) and the spurious Scottish medieval "Ossian" fragments, first published by James Macpherson in 1760. In 1764, Evan Evans (Ieuan Brydydd Hir) published Some Specimens of the Poetry of the Antient Welsh Bards Translated into English. English was predominantly the language of the eighteenthcentury Welsh cultural revivalists because it was, in part, their mission to alert the English-speaking world to the treasure trove of medieval poetry hitherto hidden from them in Welsh-language manuscripts and, in so doing, manifest to all observers the rich and distinctive identity of Welsh culture. The Revival's publications were funded and for the most part penned by members of the antiquarian London Welsh societies, the Cymmrodorion (founded in 1751) and the Gwyneddigion (founded in 1771). ${ }^{20}$ Although membership of these societies was limited to men, Sarah Prescott, in her contribution to this issue, argues that women too contributed to that eighteenth-century cultural rebirth, to a degree which has not previously been fully recognized, as anglophone poets like Ann Penny, Ann Hughes and Mary Robinson versified prose translations of the medieval Welsh bards (or fake Welsh bard, in Robinson's case).

Felicia Hemans continued the same tradition with her Welsh Melodies (1822), a collection of verses set to Welsh airs written from within a Romantic Wales now animated and, in the case of some of its patriots, radicalized by the French Revolution. Sympathetic identification with a Welsh history of colonial suppression, now publicized in English in the productions of the eighteenth-century antiquarians, also characterized the work of other lesser-known Romantic women writers. In this issue, Elizabeth Edwards' article examines the career and contribution of one of the most colourful members of this cohort, the poet and novelist Ann Julia Hatton, whose chosen pseudonym, "Ann of Swansea", spells out her adoption of a Welsh identity. While tracing Ann of Swansea's history and mapping out her career as a poet, Edwards emphasizes the significance of location for the full appreciation of a neglected writer's oeuvre; such an approach can move beyond literary recovery per se to a new evaluation of non-metropolitan writing.

\section{Women's prose in Victorian and Edwardian Wales}

The decade which saw the publication of Ann of Swansea's Poetic Trifles (1811) also marked the onset of an epoch of civic and industrial unrest in Wales, as the ironworkers of Merthyr Tydfil went on strike in protest against wage cuts in 1816, and the imposition of the Corn Laws, taxing imported grain, led to food-shortage 
riots in Carmarthen in 1818. The troubles came to a head in the 1830s with the pro-reform Merthyr Rising of 1831, in which 24 protesters were killed by the soldiery; the militant Chartist insurrection in Gwent in 1839; and the onset of the toll-gate smashing activities of the Rebecca rioters in rural west Wales in the same year. By 1840, Wales was the "most heavily militarized zone in Britain", as the English Parliament sent in soldiers to quell the unrest. ${ }^{21}$ In 1846, it was suggested in Westminster that investing in Welsh education, and in particular in the teaching of English in Wales, might be a less expensive means of regaining control of the principality. Accordingly, three monoglot English commissioners were sent into Wales to inquire into the levels of education attained by a population that was still, in many parts, monoglot Welsh. Their Reports of the Commissioners of Inquiry into the State of Education in Wales (1847) found not only that standards of education, particularly of English teaching, were deplorably low in Wales, but that "thefts, lying, cozening, every species of chicanery, drunkenness (where the means exist), and idleness" prevailed within a population thus debarred from the civilizing effects of the imperial tongue. Notoriously, it specified a "want of chastity" in women as "the giant sin of Wales", with female licentiousness being in itself

[...] sufficient to account for all other immoralities, for each generation will derive its moral tone in a great degree from the influences imparted by the mothers who reared them. Where these influences are corrupted at their very source, it is vain to expect virtues in the off-spring. ${ }^{22}$

For decades after its publication, the shock of the 1847 Report continued to reverberate within an outraged Wales, which in the mid-century was otherwise priding itself on being "the most religious nation on earth", with a considerably higher percentage of its population attending religious services than in either England or Scotland, according to the Religious Census of $1851 .^{23}$ In terms of immediate responses to the Report, one of the most effective of those who took up arms against its calumnies was Jane Williams (Ysgafell), whose pamphlet Artegall: or, Remarks on the Reports of the Commissioners of Inquiry into the State of Education in Wales appeared in 1848. Little critical attention has hitherto been paid to Jane Williams' arguments, but, in this special issue, Gwyneth Tyson Roberts contributes a detailed analysis of her pamphlet's style and substance, and also comments on its reception and Ysgafell's patron, Augusta Hall, Lady Llanover, a formidable force in the nation-rebuilding process at work in Wales in response to the Report. ${ }^{24}$

Amongst other women writers who contributed to that movement, Louisa Matilda Spooner, who signed herself "L. M. S." on the title pages of her publications, was for 150 years even more lost to posterity than Ysgafell. Of English descent but resident in Wales throughout her life, Spooner aimed in her fictions to correct its English neighbours' image of Wales as primitively barbaric, or so Rita Singer argues in her contribution to this issue on the complex political manoeuvrings within Spooner's second novel, Country Landlords (1860). Published at the time of the rise of the Liberal Party into political ascendancy in Wales, and making reference within its pages to the ideas of Giuseppe Mazzini and the 
Young Italy movement, with some of its scenes set in Italy during the Risorgimento, the novel sets Welsh issues against a European context in an attempt to correct its marginalization within a limited British cultural perspective. L. M. S.'s first novel, Gladys of Harlech (1858), also features as one of the historical fictions set in Wales to which Diana Wallace draws attention in the sixth article in this issue. Wallace argues that writers like Spooner used historical fiction not only as a nation-building device, but also as a means of inserting female figures as heroines into a history which otherwise omitted them. In Gladys, set during the period of Tudor ascendancy, it is the eponymous heroine, not Henry Tudor, who through her valiant striving saves a ravaged nation and regains her inheritance. In other novels, such as Allen Raine's Hearts of Wales (1905), set during the period of Glyndîrr's defeat, the subordinated situation of women within patriarchy is presented as paralleling the subjugation of Wales within its "union" with England, Wallace suggests.

Allen Raine, one of the most prolific and certainly the most commercially successful of all pre-First World War Welsh women writers, generally focused in her fictions, however, on portraying a more contemporary Wales. Her 1902 novel $A$ Welsh Witch includes scenes set in the coal pits which dominated late nineteenthcentury Wales, and thus features in a pioneering article on women's industrial fiction contributed to this issue by Kirsti Bohata and Alexandra Jones. During the second half of the century, Wales changed from being a largely rural to a largely industrial economy: according to the historian D. Gareth Evans, "in 1851, agriculture had accounted for 35\% and mining for $17 \%$ of the occupied male population of Wales. By 1914 agriculture had slumped to $12 \%$ and mining now accounted for $32 \%$ of the occupied male population". ${ }^{25}$ Although distanced from the life of the pits by their social class as well as their gender, and for all their characteristic use of the romance as opposed to the realist novel form, novelists like Amy Dillwyn, Anne Beale, Mallt Williams and Irene Saunderson succeeded in drawing attention to the hardships of industrial life, with its pit disasters and work-inflicted disabilities. In their concluding paragraph, Bohata and Jones attribute "the markedly and self-consciously Welsh character" of these industrial fictions to the influence of the Liberal-led fin-de-siècle Welsh Home Rule movement, Young Wales or Cymru Fydd. The final article included in the following pages, by Rosanne Reeves and myself, focuses on two Welsh-language women writers' contributions to Cymru Fydd, and discusses also the involvement of the suffragist movement in Cymru Fydd's aims and activities, as detailed in "For Women, for Wales and for Liberalism": Women in Liberal Politics in Wales 1880-1914 (2010) by the feminist historian Ursula Masson, to whose memory this special issue is dedicated. ${ }^{26}$

Inevitably, in introducing an essay collection of this kind, the many topics not included prey on an editor's mind: women's fictional portrayals of the religious revivals which periodically swept Wales from the mid eighteenth century to 1904, for example; their contribution to eisteddfod culture, from Felicia Hemans to Allen Raine and Gwyneth Vaughan; or the Welsh-language women's periodicals of the second half of the nineteenth century, which are still relatively unexplored. But it was all along the aim of this issue not only to 
fill current gaps in knowledge, but also to incite its readers to further pioneering explorations of the rich fields left untilled in the literary history of Welsh women's writing. And given the recent increase of scholarly interest in this topic, it will hopefully not be long before the publication of further relevant journal numbers and monographs: the primary materials are there in abundance, waiting investigation.

\section{Notes}

1. Sally Weale, “At Last!", Guardian, 9 May 2003, <https://www.theguardian. com/world/2003/may/09/gender.uk $>$.

2. Deirdre Beddoe, Out of the Shadows: A History of Women in Twentieth-Century Wales (Cardiff: U of Wales P, 2000), p. 183. See also, for a full discussion of women's role in the early years of the Assembly, Paul Chaney, Fiona Mackay, and Laura McAllister, Women, Politics and Constitutional Change: The First Years of the National Assembly for Wales (Cardiff: U of Wales P, 2007).

3. See Jane Aaron, "Devolved Voices: Welsh Women's Writing post 1997", Our Changing Land: Revisiting Gender, Class and Identity in Contemporary Wales, ed. Dawn Mannay (Cardiff: U of Wales P, 2016), pp. 22-41.

4. See Paul Chaney, Equality and Public Policy: Exploring the Impact of Devolution in the UK (Cardiff: U of Wales P, 2011), pp. 35-57.

5. Gillian Clarke in interview in Alice Entwistle, In Her Own Words: Women Talking Poetry and Wales (Bridgend: Seren, 2014), p. 6.

6. Kathryn Curtis, Marged Haycock, Elin ap Hywel, and Ceridwen Lloyd-Morgan, "Rhai sylwadau ar ferched a'r gyfundrefn addysg", Y Traethodydd, 141.598 (1986): 6-11 (8). See Cathryn A. Charnell-White's contribution to this issue for more material on the 1986 Traethodydd. For an English-language introduction to the work of Ann Griffiths, see A. M. Allchin, Ann Griffiths: The Furnace and the Fountain (Cardiff: U of Wales P, 1987).

7. “About Honno", Honno Gwasg Menywod Cymru/Honno Welsh Women's Press, 24 Oct. $2016<$ http://www.honno.co.uk/aboutus.php >.

8. For an English-language introduction to Kate Roberts, see Katie Gramich, Kate Roberts (Cardiff: U of Wales P, 2011).

9. See the annual bibliographies of criticism on Welsh writing in English for the 1990s in the journal Welsh Writing in English: A Yearbook of Critical Essays. For late twenty-first century figures, see the online "Bibliography of Scholarly Work in the Field of Welsh Writing in English, 2006-2010", <http://ijwwe. wordpress.com/bibliography-of-scholarly-work-in-the-field-of-welsh-writingin-english/2010-2/>.

10. Kate Chedgzoy, Women's Writing in the British Atlantic World: Memory, Place and History 1550-1700 (Cambridge: Cambridge UP, 2007), pp. 111-24.

11. Stephen C. Behrendt, British Women Poets and the Romantic Writing Community (Baltimore: John Hopkins UP, 2009).

12. For these writers' Welsh connections, see Catherine Brennan, "Felicia Hemans, Empire and Welsh Culture", Angers, Fantasies and Ghostly Fears: NineteenthCentury Women from Wales and English-Language Poetry (Cardiff: U of Wales P, 2003), pp. 63-86; Moira Dearnley, "Perdita, Wales and the Monster: Mary Robinson's Welsh Novels", Distant Fields: Eighteenth-Century Fictions of Wales (Cardiff: U of Wales P, 2001), pp. 172-89. On Mary Robinson, see also Sarah Prescott's contribution to this special issue. 
13. See, for example, Shawna Lichtenwalner on Hemans in Claiming Cambria: Invoking the Welsh in the Romantic Age (Newark: U of Delaware P, 2008), pp. 148-61; Mihoko Suzuki, "Women, Civil War, and Empire: The Politics of Translation in Katherine Philip's Pompey and Horace", The History of British Women's Writing 1610-1690, ed. Suzuki, vol. 3 (Basingstoke: Palgrave, 2011), pp. 270-86.

14. Dot Jones, Statistical Evidence Relating to the Welsh Language 1801-1911 (Cardiff: U of Wales P, 1998), p. 225.

15. See R. R. Davies, The Revolt of Owain Glyn Dîr (Oxford: Oxford UP, 1995).

16. Gwyn A. Williams, When Was Wales? A History of the Welsh (Harmondsworth: Penguin, 1985), p. 114.

17. Act of Union, 1536; qtd. in Norman Davies, The Isles: A History (London: Macmillan, 1991), pp. 492-93.

18. See Patrick Thomas, Katherine Philips (“Orinda") (Cardiff: U of Wales P, 1988).

19. See Jane Aaron, Nineteenth-Century Women's Writing in Wales: Nation, Gender and Identity (Cardiff: U of Wales P, 2007), pp. 13-24.

20. For further material on the London Welsh societies and their key members, see Bethan M. Jenkins, Between Wales and England: Anglophone Welsh Writing of the Eighteenth Century (Cardiff: U of Wales P, 2017).

21. Williams, p. 196.

22. Reports of the Commissioners of Inquiry into the State of Education in Wales (London: HMSO, 1847), pt. 2, p. 56. For a detailed discussion of the Report, see Gwyneth Tyson Roberts, The Language of the Blue Books: Wales and Colonial Prejudice (Cardiff: U of Wales P, 1998).

23. Jones, p. 413, quoting Thomas Rees on Wales in the Christian Witness, 7 May 1850: 416.

24. For further discussion of Augusta Hall's influence, see Maxwell Fraser, "Lady Llanover and Her Circle", Transactions of the Honourable Society of Cymmrodorion, 1968: 170-96.

25. D. Gareth Evans, A History of Wales 1906-2000 (Cardiff: U of Wales P, 2000), p. 9.

26. Ursula Masson, "For Women, for Wales and for Liberalism": Women in Liberal Politics in Wales 1880-1914 (Cardiff: U of Wales P, 2010). 


\title{
PROBLEMS OF AUTHORSHIP AND ATTRIBUTION: THE WELSH-LANGUAGE WOMEN'S CANON BEFORE 1800
}

\author{
Cathryn A. Charnell-White
}

\begin{abstract}
Problems of authorship and attribution pose significant methodological challenges for researchers of Welsh-language women poets before 1800 . These issues are contingent on the prevailing oral and manuscript cultures of transmission characteristic of Wales's bardic culture, from which women were largely excluded. This article explores the unstable Welsh-language canon of poetry by women and highlights examples of problematic authorship and attestation. It also interrogates the diachronic wishful thinking of the Welsh feminist agenda alongside the synchronic reality of early modern women poets: is there a coherent female tradition and was it visible to early modern women poets?
\end{abstract}

Yn lle Alis, Alias yw'r Gair a ddylae fod. Ni chlywais i fod yr un Brydyddes or Enw.

[Instead of Alis (Alice), the word should be Alias. I have not heard of a Poetess of that Name. ${ }^{1}$

This marginal note by the poet and scribe Robert Thomas (1700-74) may not express surprise at the existence of a female poet, but it does foreground the fragility not only of individual authorial reputations, but of women's engagement with Wales's bardic tradition pre-1800. Thomas refers to Alis ferch Gruffudd ab Ieuan ( $f l$. 1540-70), a poet whose surviving canon includes about eight strict-metre poems. ${ }^{2}$ Alis is privileged that her extant poems actually comprise a body of work, since the majority of known women poets before 1800 have only one surviving poem to their name. Privilege is not only part of Alis's identity as a woman and a poet, but it is also a vital element in the broader narrative of Welsh strict-metre women poets. She was the daughter of a gentleman amateur poet, Gruffudd ab Ieuan (c.14851553) of Llewenni Fechan, who, alongside the professional bard Tudur Aled (c.1465-c.1525), was an adjudicator in the 1523 eisteddfod at Caerwys, Flintshire, at which his father-in-law (Alis's maternal grandfather) was one of three commissioners who licensed the attendant bards. Alis's family was 
eminently bardic, and Elsbeth, her second cousin on her father's side, was also a poet. Alis and her modest extant canon typify the vulnerability of Wales's female poets in medieval and early modern Wales: her poems were transmitted orally for a generation or more before being committed to manuscript; her corpus includes a collaborative dimension; she is conflated with others, as her poems are attributed in manuscripts to other women poets, including her sisters Catrin and Gwen; and, despite her family's pre-eminence in Welsh bardic culture, within a few generations her reputation as a poet had been forgotten.

Born of second-wave feminist criticism and riding the third wave, researchers of Wales's medieval and early modern Welsh-language women poets are concerned with textual recovery, canon formation and the possible (re)construction of a female literary tradition. Research into the field has further underlined the fragility of the female canon by drawing attention to the practical, structural and ideological challenges faced by aspiring women poets in Wales before 1800. In this respect, the structures and expectations of Wales's native professional bardic guild, from which amateurs (both male and female) were excluded, contributed to the fragmented nature of the extant female canon. The boundaries between amateurism and professionalism could be permeable, and the main (male) canon was not immune to instability either. Questionable attestation, competing claims of authorship, multiple authorship and issues of anonymity are all contingent on the prevailing oral and manuscript cultures of transmission that characterize bardic culture. They pose significant methodological challenges to researchers of both male and female poets during the medieval and early modern periods; however, the work of female poets was particularly vulnerable. In this essay, I will explore the Welsh-language female canon pre-1800 by interrogating the diachronic viewpoint of the Welsh feminist agenda alongside the synchronic reality of early modern women poets.

\section{(Re)constructing a female canon}

The year 1986 was decisive for Welsh feminist scholarship. Not only was it the year in which Honno Press, a cooperative Welsh women's press, was founded by volunteers, ${ }^{3}$ but it also witnessed the publication of a special feminist issue of the long-running Welsh-language periodical, and bastion of the patriarchal and Nonconformist literary establishment, Y Traethodydd (The Essayist, 1845-). The landmark issue included a subject-defining article about Welsh women's poetry before $1800 .{ }^{4}$ Its impact can be measured substantively not only in the development of Welsh women's writing modules in Wales's universities, but also in scholarly outputs of both a generalist and specific nature. ${ }^{5}$ Since 1986, the work of a number of medieval and early modern women poets has been edited and critiqued: Gwenllian ferch Rhirid Flaidd (?fl. 1460s), ${ }^{6}$ 
Gwerful Mechain (c.1460-c.1502), ${ }^{7}$ Alis ferch Gruffudd ab Ieuan, ${ }^{8}$ Catrin ferch Gruffudd ap Hywel (fl. c.1500-55), ${ }^{9}$ and Angharad James (16771749). ${ }^{10}$ Poetry by Welsh women has also been anthologized, both in general anthologies and in a discrete anthology of Welsh women's poetry up to 1800, Beirdd Ceridwen (Ceridwen's Poets, 2005). ${ }^{11}$ Feminist scholarship in Wales has thus recovered a considerable canon of poetry by women before 1800 , and this has been achieved without having to answer calls to identify female voices in anonymous poems. ${ }^{12}$ The body of verse anthologized in Beirdd Ceridwen was, at the time, comprehensive and not subject to value judgments about the aesthetic or ideological merits of the poetry it contained. Additional texts have subsequently been uncovered as part of a Leverhulmefunded project, "Women's Poetry in Ireland, Scotland and Wales 1400$1800 "{ }^{13}$

The Welsh female canon before 1800 comprises over 200 individual items by about 80 named individuals, mainly from manuscript sources but also, by the eighteenth century, from print sources. This compares with around 200 items by 25 named individuals who composed in Scottish Gaelic before 1800 , around 100 items by 35 individuals who composed in Scots, and around 40 items by 15 named individuals who composed in Gaelic/Irish before that date. ${ }^{14}$ In terms of content, the Welsh women's canon before 1800 mirrors the tone of the main Welsh-language canon of the same period, both professional and amateur, and includes poems that are overtly religious and devotional, as well as poems of a more humorous nature. Elegy features prominently, as befits what was, essentially, a praise tradition, and occasional poetry is also well represented. Yet, despite its conformist nature in these respects, the canon is also remarkable for its poems of female interest: it includes several responses to the European-wide querelle des femmes, and a large number of gendered responses to love, marriage, friendship, motherhood, morality, religion and grief. Furthermore, the poets make individualistic use of "traditional" genres and conventions such as love poetry, as well as subliterary genres like the mother's advice poem.

The geographical distribution of the women poets is also telling. Most known individuals before 1800 belong to the counties of north Wales-to Caernarvonshire, Meirionethshire, Denbighshire and Montgomeryshire, where traditional strict-metre poetry had been preserved by country poets long after the professional poetic guild had ceased to exist, and where, latterly, the eighteenth-century ballad tradition was strongest. Despite suggested identifications of early strict-metre poets-namely, Elor Goch (thirteenth century) and Gwladus Hael (fifteenth century)-female poets in south Wales are few and far between until the latter part of the eighteenth century and, with the exception of the balladeer Florence Jones ( $f l$. 1775-1800), ${ }^{15}$ mainly comprise religious carollers. Welsh Methodism, which had its genesis in south Wales in the 1740s, opened up a new vein 
in women's poetry, but while women's involvement with the hymn tradition is rooted in religious carols and ballads of the seventeenth and eighteenth centuries-such as the halsing ("hailsing") tradition of Carmarthenshire, north Pembrokeshire and south Ceredigion-the female hymn tradition (largely associated with Methodism) did not come to fruition until the nineteenth century. ${ }^{16}$

The surviving Welsh texts of course represent only a portion of the verse composed by women before 1800 . Several names of women poets survive by reputation only: Helfin ferch Garadawc ab Bran; ${ }^{17}$ Elor (or Elinor) Goch; ${ }^{18}$ Gwladus Hael; ${ }^{19}$ Catrin ferch Gruffudd ab Ieuan (sister of Alis); Barbara Gethin; Mary (Malen) and Ann, the daughters of Dafydd Manuel (c.1624-1726); ${ }^{20}$ and the daughter of the hymnist William Williams of Pantycelyn (1717-91). ${ }^{21}$ The otherwise unknown Meistres ("Mistress") Bankes represents women whose poetry has survived in such illegible and fragmented form that it cannot be satisfactorily transcribed or reconstructed. ${ }^{22}$ Elisabeth Price (?fl. c.1592-1667) of Gerddi Bluog's only surviving four-line stanza, written in the margins of a Welsh Book of Common Prayer, is missing its first line. ${ }^{23}$ Pseudonyms such as Gwenddydd chwaer Myrddin (Gwenddydd, sister of Merlin), Siân Samson (Jane, daughter of Samson) and Gwen Arthur (Gwen, daughter of [King] Arthur) hint at male poets ventriloquizing women's voices, often satirically. ${ }^{24}$

Difficulties of attribution are particularly problematic in relation to the late medieval women poets, who are sometimes conflated with one another as a result of the oral transmission of their poems. Specific examples include Alis ferch Gruffudd ab Ieuan and her sisters Catrin and Gwen; Catrin ferch Gruffudd ab Ieuan with Catrin ferch Hywel ap Gruffudd; and Gwerful Fychan (b. c.1430) and Gwerful Mechain. Misattribution is also a challenge faced by contemporary researchers, especially with regard to poems composed in a woman's voice. For example, a poem of unrequited love ascribed to Elen Gwdmon survives in only one manuscript witness, yet it bears all the generic hallmarks of Renaissance female persona poems and their use of masculine discourse to ironic ends. ${ }^{25}$ Similarly, closer analysis of the manuscript context suggests that a song of female friendship copied by Marged Dafydd (c.1700-85?) was written not by Catrin Madryn (d. 1671), but on her behalf by an unnamed male poet. ${ }^{26}$

Despite having to grapple with issues of conflation, competition and collaboration, researchers and textual scholars have not only been able to (re)construct a canon of Welsh women's poetry, but have also provided an accompanying narrative of women's engagement with Welsh-language bardic culture and a putative female tradition. The surviving female canon was shaped by the bardic culture of its time and reflects the vicissitudes of strict metre and free metre during the course of the early modern period. 


\section{Strict-metre poetry}

The earliest extant poems by women belong to the fifteenth century and are in the distinctively Welsh 24 strict metres that are characterized by cynghanedd ("harmony"), an intricate metrical system that combines consonance, alliteration and internal rhyme. ${ }^{27}$ It was traditionally the preserve of Wales's professional medieval poetic guild and its elite patrons: the indigenous princes of Wales (c.1137-1282) in the first instance and, in its latter stages, the Welsh nobility and clerics (1282-c.1650). Rules surrounding membership of the guild were strict: like its Gaelic counterpart in Ireland, the guild also had a hereditary dimension, and poetic families have been identified. ${ }^{28}$ Professional poetic training involved the acquisition of cynghanedd and a store of mythological and historical knowledge, which facilitated the poet's role as guardian of Welsh cultural memory. Dependent on patronage, the professional poetic "tradition" was essentially one of panegyric and elegy. ${ }^{29}$ In the wake of the Tudor Acts of Union $(1536,1543)$, anglicization opened up lucrative opportunities in the new administration to the noble and ecclesiastical classes who had formerly patronized Wales's elite bardic culture. The professional guild lost its cultural currency amongst its former patrons and became increasingly diminished, until it finally became defunct in the seventeenth century with the death of Siôn Dafydd Las (d. 1694). ${ }^{30}$

Against this backdrop, the earliest surviving poems by women are tentatively identified as the work of a mother and daughter at the end of the fifteenth century: Gwerful Fychan and Gwenllian ferch Rhirid Flaidd. Both women's claims to the poems ascribed to them are, however, equivocal, and attest to arguments presented by Ceridwen Lloyd-Morgan and Nia Powell about women poets' greater dependency on oral transmission. ${ }^{31}$ Gwerful Fychan's poems were transmitted orally for so long that local oral tradition conflated her with Gwerful Mechain, whose own canon comprises 19 strictmetre poems, both secular and profane in nature. ${ }^{32}$ Two poems in englyn form (a pithy four-line stanza) attributed to Gwerful Fychan were transmitted orally until they were published in 1882 in the biography and collected essays of the Reverend Robert Thomas (Ap Vychan, 1809-80). ${ }^{33}$ An ode to a stallion ("Cywydd y March Glas"), also attributed to Gwerful Fychan, is transcribed in three manuscripts, as well as in Ap Vychan's biography; all three manuscripts are local to Bala and belong to the eighteenth century. The repercussions of such a long process of oral transmission can be seen not only in textual variations and diversity of line order, but also in the accretion of 12 lines from a cywydd by the professional poet Tudur Aled. ${ }^{34}$ Gwenllian ferch Rhirid Flaidd's identity is also contested. Her pseudonym connects her with the twelfth-century nobleman Rhirid Flaidd ap Gwrgenau, but the linguistic and stylistic features of the stanza that bears her name belong to the fifteenth century. Dafydd Johnston identifies her as the daughter of the poets Gwerful 
Fychan and Tudur Penllyn, whose son, Ieuan, was also a practising poet. ${ }^{35}$ Only one out of six manuscript witnesses attributes the englyn to Gwenllian ferch Rhirid Flaidd, and Marged Haycock makes a case for a third person speaking about Gwenllian. ${ }^{36}$

In a pattern that is replicated in early modern Britain and Europe ${ }^{37}$ a considerable number of these early Welsh women poets were privileged noblewomen, particularly (but not exclusively) those who composed strict-metre verse. For example, Elsbeth Fychan (fl. 1530) and Jane Fychan (?b. 1590s) were gentlewomen who composed free-metre verse. Many women poets, through their association with literary fathers or husbands, can also be said to have benefitted from the support of a familial bardic circle. Alis, Catrin and Gwen, daughters of Gruffudd ab Ieuan, have already been mentioned in this respect, and we can add many others. Gwerful Mechain was an active member of the bardic circle that revolved around Dafydd Llwyd of Mathafarn and, through her husband, John ap Llywelyn Fychan, she was related to the poet Llywelyn ab y Moel (d. 1440). ${ }^{38}$ If, indeed, Gwladus Hael can be identified as Gwladus ferch Siencyn ap Rhys Fychan, then she belonged through marriage to the poet Ieuan Gethin (fl. c.1450). ${ }^{39}$ Catrin ferch Gruffudd ap Hywel was related to the professional poet William Cynwal (d. 1587/88), and Elsbeth Fychan was the daughter of the gentleman poet Siôn ap Hywel ap Llywelyn Fychan and, therefore, second cousin of Alis ferch Gruffudd ab Ieuan and her sisters. Elisau, father of Gaenor ferch Elisau ab Wiliam Llwyd (fl. 1583), was a cultured patron of professional bards. Jane Fychan was the wife of the translator and poet Rowland Vaughan of Caer-gai (d. 1629), whose daughter, Margaret, is also remembered as a poet. ${ }^{40}$ Elisabeth Price of Gerddi Bluog was the daughter-in-law of the poet and humanist Edmwnd Prys (1543/44-1623), and a cousin of the antiquary and collector of manuscripts Robert Vaughan of Hengwrt (c.1587-1667). Catherin Owen (d. 1602) was married to the Oxford-educated poet Dafydd Llwyd of Henblas (1588-1619), and Elin Thomas (d. 1609) was married to a gentleman poet, Ifan Tudur Owen ( $f l$. 1627).

The bias towards strict metre in fifteenth- and sixteenth-century examples of Welsh poetry by women indicates the tenacity of Welsh bardic culture as a defining feature of native polite sociability and refined culture, despite the insidious process of cultural anglicization that became more pronounced in the years following the Tudor Acts of Union. The patronage, performance and production of strict-metre verse were part of the native polite culture of the privileged social class of the women named above. In light of the fact that women (and low-born men) were effectively excluded from the professional bardic tradition, it is highly likely that Gwerful, Alis, Catrin, Elsbeth, Gaenor and others heard strict-metre poetry declaimed by professional poets on formal and informal occasions at home, and also learned the art from their fathers, husbands or other male relatives. ${ }^{41}$ Thus, the 
women poets' family connections confirm Dafydd Johnston's work on medieval amateur poets, in which he has shown that family bonds were as important as poetic networks to budding amateur poets, both male and female. ${ }^{42}$

In the face of a professional guild that guarded its professional status, noble women, like amateur gentlemen, relied on having "a good ear" to pick up the rules of strict-metre poetry. As Nia Powell has argued, however, the composition and declamation of strict-metre poetry had been traditionally associated with the male sphere: "Welsh law", she points out, "distinguished between what men and women should hear, stipulating that women should be taken aside to be greeted in poetry not in the formal strict metres" ${ }^{43}$ The amateur copier of manuscripts, Richard Langford (d. 1578), clearly situated free-metre verse in a female sphere: "In days gone by when I was keeping vigil at St Mary's Chapel, Pylltyn, the professional poets performed cywyddau and awdlau and the women sang carols and free-metre songs". ${ }^{44}$ By the eighteenth century, strict metre was largely the preserve of poets with antiquarian leanings and bardic self-identity-a label that is a loose fit for Angharad James and Marged Dafydd, since both women also collected manuscripts and transcribed poetry, for which they were recognized by the antiquary Lewis Morris (1701-65). ${ }^{45}$ Both women lived in regions that maintained a strong native literary culture, in both strict metre and free metre. ${ }^{46}$

\section{Free-metre poetry}

The model of family coteries that overlapped with broader local networks of poets is not as clear-cut with respect to women who composed free-metre poetry. Free-metre poetry offered greater freedom of expression to practitioners because, unlike the strict metres, it did not require extensive apprenticeship and was not tied to elite culture. ${ }^{47}$ Examples include Jane Fychan of Caer-gai, wife of Rowland Vaughan, whose poetic discourse links her with the poet Huw Cadwaladr; Mrs Wynne of Rhagad (fl. 1720-47), who discoursed with the poet Robert Humphreys (Robin Ragad, fl. 1720); and Ann Hughes, the daughter of the pre-eminent balladeer Jonathan Hughes (Bardd Pengwern, 1721-1805). The decline of Welsh strict-metre poetry in the early modern period coincided with the ascendancy of free-metre verse and song. ${ }^{48}$ However, cynghanedd and the strict metres retained their cultural valency, despite being in the hands of amateur country poets, especially during the eighteenth century when Welsh cultural revivalists and British Romantics rediscovered "the Welsh bard" and sought to redefine the image. ${ }^{49}$ The appropriation of the genres of the professional medieval poetic guild by country poets for their own purposes was part of a wider process of the democratization and commodification of Welsh literary culture. This process came to fruition in the eighteenth century, the golden era of popular literature such as almanacs, ballads and dramatic interludes, aided by a vibrant native print and publishing 
culture, and gradually undermined the correlation between strict-metre poetry and high culture. In fact, as had been the case in the late medieval period and throughout the early modern period, many eighteenth-century Welsh poets remained culturally and metrically amphibious: they participated in both high and low culture, and were proficient in both strict-metre and free-metre verse, even if they generally held the former in higher esteem. Angharad James and Marged Dafydd, who composed both strict-metre and free-metre verse, belong to this category, and their interest in both the practice and transcription of poetry places them on the peripheries of the eighteenth-century cultural revival, which was directed and realized by a network of male poets and antiquaries that encompassed bardic networks in Wales and the Welsh diaspora in London's Welsh societies. ${ }^{50}$

Women poets of the seventeenth century, like their male counterparts, embraced the increasingly popular free metres: the first examples of freemetre poems are by Elsbeth Fychan, Jane Fychan and Catrin ferch Ioan ab Siencyn (?before c.1621). Elsbeth Fychan's only extant poem, a poem of reconciliation with her brother, whom she tries to restore to the Catholic faith, is the earliest surviving free-metre poem by a woman and the only example before $1600 .^{51}$ Elsbeth's poem is interesting not only as a highly personal response to the success of the Protestant Reformation in Wales, but also as an example of free-metre poetry by a member of a family otherwise committed to the strict metres. During the seventeenth century, the volume of surviving free-metre poems by women increased, although the strict-metre englyn also held its ground. In this period, it is also noticeable that the women poets belong to more diverse social backgrounds. By the eighteenth century, popular literature was better preserved; however, no poetry by women seems to have been published in the century's annual almanacs, and only a handful of female balladeers saw their work in print: Lowri Parry (fl. 1738-60), Jane Pugh ( $f l .1757)$, Grace Roberts ( $f l .1766-80)$, Florence Jones and Rebecca Williams ( $f l$. 1810-20). However, the very existence of these female balladeers highlights not only the consolidation of popular literature in the eighteenth century, but also the economic and cultural currency that women could command within it. Although male and female poets coexisted, some male poets did not know how to deal with women who actively participated in the male world of poetry. The poet Rees Ellis (fl. 1714) could not desist from portraying Lowri Parry as the object of poetry, and played on both her physical beauty and the beauty of her poetry in his own poorly crafted englynion ("stanzas"):

Drwy serch, fy annerch i Lowri Parry,-at Lowri

Nef lariedd, rwy'n gyrru,

Sydd brydyddes gynnes gu,

A llais cymwys, eos Cymru. 
Diddanwch a harddwch yw hon-a chymwys

Yng nghwmni prydyddion;

Fel mwsg deniol ymysg dynion,

Handsoma ei dawn a sangodd don.

[With affection, my address to Lowri Parry-I send

it to Lowri, gentle heaven,

who is a warm, dear poetess,

and a proper voice, the nightingale of Wales.

She is entertainment and beauty-and worthy to be

in the company of poets;

like alluring perfume amongst men,

(she is) the most handsomely gifted to walk the earth.] ${ }^{52}$

Firmly positioned in the publishing and sales networks of their day, and with a willing audience for their ballads, female balladeers such as Lowri Parry are the closest that Welsh literary culture has to professional women poets until the twentieth century. The works of women hymnists such as Ann Griffiths (1776-1805), Nansi Jones (née Rhydderch, 1760-1833) and Martha Williams (1766-1845), who did not write for earthly profit, were not published until the nineteenth century. ${ }^{53}$

\section{The synchronic reality of the female tradition}

The preceding section, enabled primarily by research undertaken since 1986, sketches the surviving female canon, as well as the metrical, socio-economic, geographic and gendered dimensions of women's engagement with Welsh bardic culture, while also tracing its increasing critical mass. The outline also suggests, if only inadvertently, a neat retrospective and evolutionary narrative of a female tradition. It gives the impression of realizing the call made in Y Traethodydd in 1986 to discover a coherent female tradition. But just how meaningful and visible was this putative female poetic tradition to the poets themselves?

Dafydd Jones of Trefriw (?1703/08-85) was, perhaps, the first to signpost what could be termed a "female tradition". He was a poet, printer and collector of manuscripts-an autodidact who encapsulates the democratized character of eighteenth-century bardic culture. In a series of elegiac englynion to the poet Angharad James, he establishes a sense of succession by comparing her reputation for both levity and gravity with that of Gwerful Mechain, whose own poems, both sacred and profane, were admired by medieval and early modern manuscript compilers:

Angharad, gariad ddigweryl,-ddistaw,

Dda ystyr, fwyn annwyl;

A'i gyrfa megis Gwerful:

Un wedd â hi 'nhuedd hwyl. 
[Angharad, quiet uncomplaining love

of good meaning, gentle (and) dear;

and her career like Gwerful's:

(she is) the same as her in a tendency for fun.] ${ }^{54}$

Jones also preserved many poems by women for posterity in his own manuscripts: poems by Gwerful Mechain and Angharad James are copied in his hand, as are some englynion by Alis ferch Gruffudd ab Ieuan. ${ }^{55}$ If commonplace books and manuscripts can be considered exercises in canon formation on a personal or micro level, then Dafydd Jones clearly rated the work of these women. However, he chose not to anthologize them in his Blodeu-gerdd Cymry (Welshmen's Anthology, 1759), ${ }^{56}$ a minor milestone in the process of canon formation in Wales that included only one poem by a womannamely, a free-metre religious deathbed confession by Margaret Rowland of Llanrwst (1621-1712). ${ }^{57}$ Jones's anthology is largely of contemporary poetry, but his omission-and that of the handful of other eighteenthcentury anthologists-means that Welsh women poets were not anthologized, as such, until the nineteenth century, in collections such as Cell Callestr (Cell of Flint, 1815), Blwch y Cantorion (Singers' Box, 1838) and Gorawen Meirion (The Joy of Meirionethshire, 1825).

Turning to the women poets themselves and how they perceived a female tradition, several poems which address female contemporaries or female friends have survived, but the poetic and contextual evidence demonstrates explicitly that women poets who were aware of their female forerunners are the exception rather than the rule. Gwerful Mechain authorizes her erotically framed critique of the poetic motif of the "jealous husband" (eiddig) by alluding to the poetic authority of her forerunner, Gwenllian ferch Rhirid Flaidd, whose only surviving englyn has a suggestive, rather than explicitly erotic, edge:

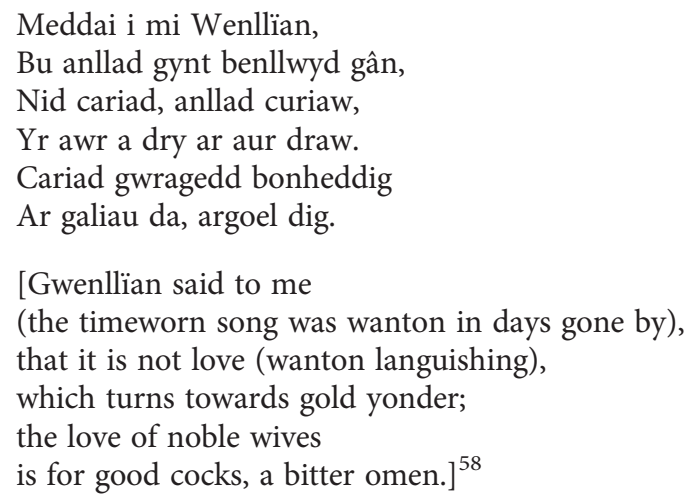

Gwerful herself is not referenced by other women poets; however, some of her work is preserved in collections of poetry by other women and, more 
surprisingly perhaps, in a collection of poetry kept at Dolwar Fach, the home of the Methodist hymnist Ann Griffiths. ${ }^{59}$ Despite the fact that one of Gwerful's most well-regarded cywyddau, "Dioddefaint Crist" ("Christ's Suffering"), was copied in Angharad James's personal manuscript, ${ }^{60}$ it is impossible to determine whether Angharad James was aware of the fragile connections suggested by Dafydd Jones of Trefriw, above, between Gwerful Mechain and herself. Marged Dafydd preserved the work of a number of her peers and near contemporaries in her own manuscripts, including poetic discourses with her aunt, Margaret Rowland, and Angharad James's lament for the loss of her son, Dafydd Wiliam (d. 1729) ${ }^{61}$ Although it cannot be proved that she did so systematically, the act of including the texts in her personal manuscript was a small act of validation and canonization; Marged Dafydd sought to legitimate Angharad James and others.

When we look closely at the evidence for a female tradition, it becomes apparent that the diachronic narrative of contemporary feminist scholars is at odds with the synchronic reality-indeed, contingency-of Wales's Welsh-language women poets. Amongst the women poets themselves, the concept of a specifically poetic succession or tradition was fragmented, and, furthermore, only these exceptional individuals seem to have been aware of female contemporaries or precursors. This is hardly surprising since, at any given time during the early modern period, women poets were in a minority, and, like male poets, their poetry was only accessible through oral and manuscript culture. Despite the ascendancy of print culture in seventeenth-century Wales, Welsh women were simply not as visible in print as their male counterparts during the eighteenth century, and when they were, they were better represented in the ballad pamphlets of popular culture rather than in the anthologies that shaped the burgeoning Welsh canon. Welsh women poets of both strict-metre and free-metre forms, like their popular and amateur male counterparts, were marginal to the process of canon formation, and it is fair to say that while recent scholarship has discovered a fairly substantial female canon, it has not found a cohesive female tradition. Accordingly, it is more useful to think of Wales's medieval and early modern women poets in terms of a diversity of independent, localized poetic coteries (both mixed and women only) that occasionally interlinked, rather than to think in terms of a continuous female poetic tradition.

\section{Poetic circles}

Surviving evidence for these poetic circles, coteries or networks is partial, much like the evidence for women poets themselves, yet the picture that emerges from the remaining evidence is of productive and good-humoured interaction and collaboration with male poets, both professional and amateur. Bardic circles were sites for poetic training and also for sustaining 
poetic activity. Gwerful Mechain, at the turn of the sixteenth century when bardic culture still enjoyed the support of noble and ecclesiastic patrons, belonged to a circle of amateur poets that centred on Dafydd Llwyd of Mathafarn (c.1395-1486). The poetic patriarch was her poetic teacher, but too literal a reading of their poetic discourses, which were often satirically framed by the conventions of traditional love and erotic poetry, fed a tradition that they were also lovers. ${ }^{62} \mathrm{~A}$ similar narrative has emerged with regard to Gwladus Hael and Ieuan Gethin. ${ }^{63}$ Some of Gwerful Mechain's most iconic poems are a direct result of network activity and poetic rough and tumble. Her "Cywydd y gont" ("Cywydd to the cunt") is an intelligent subversion of the love poetry of her male contemporaries, whose conventional and systematic descriptions of women studiously avoided any mention of "the place where children are conceived":

Pob rhyw brydydd, dydd dioed,

Mul rwysg wladaidd rwysg erioed,

Noethi moliant, nis gwarantwyf,

Anfeidrol reiol, yr wyf

Am gerdd merched y gwledydd

A wnaethant heb ffyniant ffydd

Yn anghwbl iawn, ddawn ddiwad,

Ar hyd y dydd, rho Duw Dad.

Moli gwallt, cwnsallt ceinserch,

A phob cyfryw fyw o ferch,

[...]

Diffrwyth wawd o'i dafawd ef.

Gadu'r canol heb foliant

A'r plas lle'r enillir plant ...

[Every foolish drunken poet, boorish vanity without ceasing, (never may I warrant it,

I of great noble stock,)

has always declaimed fruitless praise

in song of the girls of the lands

all day long, certain gift,

most incompletely, by God the Father:

praising the hair, gown of fine love,

and every such living girl

(...)

fruitless eulogy with his tongue.

Leaving the middle without praise

and the place where children are conceived .... ${ }^{64}$

In this poem, Gwerful Mechain challenged her fellow poets, using their own generic conventions-specifically, the conventional step-by-step description of a woman-to undermine the inherent misogyny of their arguments. She was particularly well known as a "discoursing poet" (ymrysonfardd) and 
associated with some of the most prominent professional poets of her day, as well as the amateur poets of her locality, thus attesting to the permeable boundaries of professionalism and amateurism in the strict-metre world. She was satirized cruelly on one occasion at the court of the Bishop of Bangor; it is implied that, by turning in male circles, she transgressed both social and bardic mores of female propriety: "Gweiddi y mae Gweirfyl, gwiddon-ysgethrin [Gwerful, horrible hag, is shouting]" 65

Marged Dafydd has the most extensive and varied poetic circle. Internal evidence in her surviving canon suggests that her poetic talents were nurtured by a largely familial poetic coterie, which included her mother, Ann Dafydd (d. 1726); her aunt, Margaret Rowland (fl. 1738); and a male relative, John Davies of Bronwion (d. 1727). The elegy Marged composed for her mother suggests that Ann had coached her in strict-metre poetry, as well as harp music:

Pan ddiffoddes lampes lon,

Darfu'r golau, difr gwiwlon!

Ysgol im oedd, rho' floedd flin,

A'm athro wrth fy meithrin.

[When the happy lamp was extinguished, the light ceased, happy (and) proper melody!

She was my school (I give an angry cry), and, as she raised me, my tutor. $]^{66}$

By 1728, Marged Dafydd was corresponding with the promising young poet Michael Prichard (1709-33) and advising him on the niceties of cynghanedd and the strict metres. To him, she is poetry's foster-mother, as well as the true mother of poetry:

Mamaeth Barddoniaeth, bêr ddinam,-hynaws

I'th henwi mwyneiddfam:

Nod lliwusfodd, nid llysfam,

Gwar o fil, ond gwir fam.

[Foster-mother of poetry, sweet (and) pure,- - genial

to be called a gentle mother:

with a mark of a beautiful manner, not a stepmother,

(civilized amongst a thousand [people]), but a true mother.] ${ }^{67}$

Marged Dafydd is self-effacing and demurring in her response, as in her letters to Dafydd Jones of Trefriw, capitulating to expectations of passive femininity by declaring herself "ffug enethan ffôl [a false, foolish lass]". ${ }^{68}$ In a poetic discourse with her aunt, she confirms that poetry was part of her family's cultural inheritance-"Roedd dwned yn y dynion [The men had knowledge of poetic grammar]"-adding pensively that interest in poetry is now waning in the family: 


\section{Llwyr y troes yn llai'r trysawr}

A'r dwned a lusged i lawr

[The treasure (i.e. Welsh poetry) is thoroughly diminished and poetry has been dragged down]. ${ }^{69}$

She also complained about the decline of Welsh strict-metre poetry in her native county in correspondence with Michael Pritchard and Dafydd Jones. ${ }^{70}$ Her poetry, manuscripts and correspondence demonstrate that she was also on good terms with Rice Jones of Blaenau and with other local female poets whose work is preserved in her manuscripts. She may also have known Angharad James. ${ }^{71}$ The two women could certainly have overlapped during the 1720s and 1730s, but no correspondence survives and their friendship was not enacted in their poetry either. While Michael Prichard legitimately defined her creative and nurturing role in their relationship in safe, maternal terms, it is no accident that Marged Dafydd, who was unmarried, childless and financially secure, is one of the most prolific poets in early modern Wales.

Evidence of female-only coteries is scant. As well as transcribing poems by other women of her locality, Marged Dafydd also addressed several female friends in verse, but the support which friendship provided is most clearly seen in her poetic discourses with her aunt, Margaret Rowland. When her muse had frozen, the aunt turned to her niece for comfort and inspiration:

Deilliaw a chonffwrdd di elli

'Y mhen doeth a'm henaid i.

[You can support and comfort

my wise head and soul]. ${ }^{72}$

Friendship offered women an opportunity to support one another, as in equivalent coteries or societies of friendship in England. ${ }^{73}$ Consonant with English and European models, a handful of poems by Marged Harri (? $f$ l. 1550s, a copy of which survives in Marged Dafydd's hand), Siân Briwtwn (Jane Brereton, wife of Kynfrig Powell, fl. 1581-1613), Catrin Madryn, Angharad James and Marged Dafydd attests to the importance of female friendship to women poets throughout the early modern period. ${ }^{74}$ These poems are excellent examples of the way in which women poets' alterity allowed them to use the generic conventions of Wales's bardic tradition to their own ends. Strikingly, Marged Harri, Siân Briwtwn, Catrin Madryn and Marged Dafydd all follow the same rubric in their poems: the llatai or "love messenger". According to convention, a poet would send an animal or a bird as a "love messenger" to his beloved, but, for these women poets, the animals are a means of strengthening the bonds of friendship that have been loosened by absence. Marged Dafydd sends a swallow in the 
following cywydd, for example, as messenger to an absent, much-missed female friend:

Dan ganu, sydd gynnes waith, Y wennol, wyd ddiweniaith Wir gennad, orau ganu, Y wennol fwyn, welaf $i$, Nac un aderyn ar dir I gario neges geirwir. Ei di trosof mewn traserch I'r Creuddyn i mofyn merch? $[\ldots]$ Pedair sydd brudd mewn braw, A'u golwg braidd ag wylaw [...] Prudd nychlyd ar hyd yr ha' Am gynnes, aeres ara'; Eisio ei gweled, Luned lon, Siŵr fawredd yn sir Feirion.

[Singing, which is genial work, swallow, you are without flattery a true messenger, the best (for) singing (the gentle swallow that I see) than any bird on land to carry a true message.

Will you go in great love on my behalf to the Creuddyn to inquire about a girl? (...)

Four (friends) are sad and worried, and look as though they are about to weep (...)

They languished in sadness all summer for the warm, graceful heiress; they wish to see her, merry Luned, in Meirionethshire, for sure. $]^{75}$

Marged Harri's cywydd, in which she sends a fish (a sewin) as a messenger to a female friend, ${ }^{76}$ survives in five manuscript copies, one of which issues the following paratextual claim: "Marged Harri drwy help Edmwnd Prys, Edmwnd Prys ai Cant [Marged Harri with the help of Edmwnd Prys, Edmwnd Prys composed it]" - an assertion of a collaborative venture, followed by a statement undermining that very collaboration. ${ }^{77}$ The paratext is unhelpful and we cannot glean from it to what extent it reflects the scribe's conviction that a woman could not have composed a strict-metre cywydd, even with the help of an accomplished, recognized poet. ${ }^{78}$ If Edmwnd Prys is, indeed, the author of the poem, then why did the scribe mention Marged Harri at all? Did the male poet merely guide and tutor her or did he write the entire poem himself? If he did, then why not follow bardic convention and frame 
the poem as a "poem of request" (canu gofyn), which he could have written on Marged's behalf in his own voice while also retaining authorship of the poem? There can be no definitive answer, so should Marged Harri remain in the canon or be omitted? Ultimately, this case demonstrates how the Welsh context accords with the broader picture of early modern women's writing, in that the collaborative and context-driven nature of verse such as this, produced in a coterie environment, challenges received wisdom about autonomous and uncontested authorship, as well as the notion of a canon formed by the works of individual authors. ${ }^{79}$

In conclusion, Welsh feminist research (including my own work) is inevitably highly invested in the identification of a lineage of female poetic forebears, as well as in claiming ownership of a discrete body of female verse. However, it is vital that we abide by the historicist imperative of viewing literature not only within its own historical and cultural context, but also within our own. In this respect, we should recognize that the notion of a female poetic tradition is a recent artificial construct, highly motivated by the understandable and well-meant enthusiasm of researchers like myself to recover forgotten poets and neglected texts. Composite and collaborative works, such as that by Marged Harri and Edmwnd Prys, as well as works attributed (or misattributed) to more than one poet, remind us that authorship, too, is a construct. Geographic and social patterns emerge, but only occasionally was a poetic baton passed from woman poet to woman poet. In their own time and place, being part of a female tradition and having "poetic foremothers" had very little practical meaning for medieval and early modern women poets themselves, and is more ideologically meaningful to modern Welsh women poets and, of course, to those of us currently studying the history of women's poetry in Wales, who are privileged enough to bear witness to the developments across time and the accumulated construct that is the Welsh female canon.

\section{Notes}

1. Add. ms. 10313, 34b/54, fol. 34b/54, British Lib. (BL), London.

2. Cathryn A. Charnell-White, ed., Beirdd Ceridwen: Blodeugerdd Barddas o Ganu Menywod hyd tua 1800 (Swansea: Cyhoeddiadau Barddas, 2005), nos. 21-28 (hereafter $B C$ ). Unless otherwise stated, the texts and biographies of the women can be found in $B C$.

3. “About Honno", Honno Gwasg Menywod Cymru/Honno Welsh Women's Press, 24 Oct. $2016<$ http://www.honno.co.uk/aboutus.php $>$.

4. Kathryn Curtis, Marged Haycock, Elin ap Hywel, and Ceridwen Lloyd-Morgan, "Beirdd Benywaidd yng Nghymru cyn 1800", Y Traethodydd, 141 (1986): 12-27.

5. For generalist studies, see Jane Cartwright, "Women Writers in Wales", The History of British Women's Writing, 700-1500, ed. Liz Herbert McAvoy and Diane Watt, vol. 1 (Basingstoke: Palgrave, 2013), pp. 60-71; Nia Powell, 
"Women and Strict-Metre Poetry in Wales", Women and Gender in Early Modern Wales, ed. Michael Roberts and Simone Clarke (Cardiff: U of Wales P, 2000), pp. 129-58; Ceridwen Lloyd-Morgan, "Oral Composition and Written Transmission: Welsh Women's Poetry from the Middle Ages and Beyond", Trivium, 26 (1991): 87-102 and "Women and Their Poetry in Medieval Wales", Women and Literature in Britain, 1150-1500, ed. Carol M. Meale (Cambridge: Cambridge UP, 1993), pp. 183-201.

6. Dafydd Johnston, "Gwenllian ferch Rhirid Flaidd”, Dwned, 3 (1997): 27-32.

7. Nerys A. Howells, ed., Gwaith Gwerful Mechain ac Eraill (Aberystwyth: Centre for Advanced Welsh and Celtic Studies, 2001).

8. Gwen Saunders Jones, Alis ferch Gruffudd a'r Traddodiad Barddol Benywaidd (Caernarfon: Gwasg Pantycelyn, 2015).

9. Cathryn A. Charnell-White, "Canu defosiynol Catrin ferch Gruffudd ap Hywel”, Dwned, 7 (2001): 93-120.

10. Nia Mai Jenkins, “A'i Gyrfa Megis Gwerful”: Bywyd a Gwaith Angharad James", Llên Cymru, 24 (2001): 79-112 and "'Ymddiddan Rhwng y Byw a'r Marw, Gŵr a Gwraig' (Angharad James)”, Llên Cymru, 25 (2002): 43-45.

11. Katie Gramich and Catherine Brennan, eds., Welsh Women's Poetry, 14502001: An Anthology (Dinas Powys: Honno, 2003); Jane Stevenson and Peter Davidson, eds., Early Modern Women Poets (1520-1700): An Anthology (Oxford: Oxford UP, 2001); BC.

12. Curtis et al., 14; Powell, pp. 148, 158.

13. "Women's Poetry in Ireland, Scotland and Wales 1400-1800", 24 Oct. 2016 $<$ http://womenspoetry.aber.ac.uk/en/>.

14. My thanks to colleagues on the "Women's Poetry in Ireland, Scotland and Wales 1400-1800" project for providing the figures.

15. $B C$, nos. 142,143 ; pp. 406-07.

16. Jane Aaron, “Adnabyddus neu weddol adnabyddus': cyd-awduresau Ann Griffiths yn hanner cyntaf y bedwaredd ganrif ar bymtheg", Cof Cenedl, ed. Geraint H. Jenkins, vol. 12 (Cardiff: U of Wales P, 1997), pp. 103-35; E. Wyn James, "Merched a'r Emyn yn Sir Gâr”, Barn, 402/403 (1996): 26-29 and "Ann Griffiths: y cefndir barddol", Llên Cymru, 23 (2000): 147-70.

17. She is included in a list of ancient poets by Edward Williams (Iolo Morganwg, 1747-1826) to attest to the bardic primacy of Williams' native Glamorgan; 13087E, 248, Natl. Lib. of Wales (NLW), Aberystwyth. See Cathryn A. Charnell-White, Bardic Circles: National, Regional and Personal Identity in the Bardic Vision of Iolo Morganwg (Cardiff: U of Wales P, 2007), pp. 82-117.

18. Edward Williams claims that Elor, daughter of Catrin (c.1198-1244), daughter of Llywelyn ap Gruffudd ab Iorwerth Drwynwn was the founding member of the bardic Chair of Tir Iarll. NLW 13131A, p. 140.

19. She is tentatively identified as Gwladus ferch Siencyn ap Rhys Fychan. See Marged Haycock, "Dwsin o brydyddesau? Achos Gwladus 'Hael' ac eraill", Dwned, 16 (2010): 93-114.

20. R. Williams, "Dafydd Manuel a'i dylwyth", Y Geninen, 1884: 305-07; couplets by Malen qtd. on 306. Also qtd. in Tegwyn Jones, ed., Anecdotau Llenyddol (Talybont: Y Lolfa, 1987), p. 28.

21. Jones, Anecdotau, p. 37.

22. Ms. 184, ii, Christ College, Oxford (facsim. NLW 6495C, ii).

23. NLW 21728B; BC, no. 43.

24. Curtis et al., 14. 
25. $B C$, no. 48. Compare with a similar song in a female voice by Siôn Tudur (d. 1602) that is ascribed to an Ann Gwyn of Denbigh in the paratext of one manuscript witness. For the genre in general, see Gail Reitenbach, "Maydes are simple, some men say': Thomas Campion's Female Persona Poems”, The Renaissance Englishwoman in Print: Counterbalancing the Canon, ed. Anne M. Haselkorn and Betty S. Travitsky (Amherst: U of Massachusetts P, 1990), pp. 80-95 (81).

26. $B C$, no. 59 ; the poem follows a series of request poems by male poets in NLW Cwrtmawr 128A.

27. Mererid Hopwood, Singing in Chains: Listening to Welsh Verse (Llandysul: Gomer, 2004).

28. J. E. Caerwyn Williams, "The Development of Poetry", The Irish Literary Tradition, ed. J. E. Caerwyn Williams and Patrick K. Ford (Cardiff: U of Wales P, 1992), p. 159; Marc Caball, “The Literature of Medieval Ireland, 1200-1600: From the Normans to the Tudors", The Cambridge History of Irish Literature, ed. Margaret Kelleher and Philip O'Leary, vol. 1 (Cambridge: Cambridge UP, 2008), p. 78.

29. A. O. H. Jarman and Gwilym Rees Hughes, eds., A Guide to Welsh Literature, vol. 2 (Swansea: Christopher Davies, 1979).

30. See Ceri W. Lewis, “The Decline of Professional Poetry”, A Guide to Welsh Literature c. 1530-1700, ed. R. Geraint Gruffydd, vol. 3 (Cardiff: U of Wales P, 1997), pp. 29-74.

31. Lloyd-Morgan, "Women".

32. $B C$, no. 9 .

33. M. D. Jones and D. V. Thomas, eds., Cofiant a Thraethodau Duwinyddol y Parch R. Thomas, (Ap Vychan), Bala (Dolgellau: W. Hughes [1882]); BC, nos. 1, 3.

34. $B C$, no. 5 ; p. 48 for apparatus criticus.

35. Johnston, "Gwenllian”.

36. Haycock, 96.

37. Betty S. Travitsky, "Introduction: Placing Women in the English Renaissance", Haselkorn and Travitsky, p. 25. For medieval Wales, see Howells, pp. 40-43.

38. Howells, p. 4.

39. Haycock, 112.

40. A version of $B C$, no. 24 by Alis ferch Gruffudd ab Ieuan is attributed to Margaret Vaughan in NLW Cwrtmawr 41B, ii, fol. 118 and to "merch R. V." (R. V.'s daughter) in NLW $836 \mathrm{D}$, fol. 22. $B C$, no. 53 is also attributed to Margaret Rowland, although Dafydd Jones of Trefriw gives contradictory information about her parentage in NLW 9B and Blodeu-Gerdd Cymry (Shrewsbury: printed for the author, 1759).

41. Powell, p. 135.

42. Dafydd Johnston, Llên yr Uchelwyr: Hanes Beirniadol Llenyddiaeth Gymraeg 1300-1525 (Cardiff: U of Wales P, 2005), p. 46.

43. Powell, p. 130.

44. Cardiff 2.634, Cardiff Central Library [formerly Hafod 24]: fols. 353-57; translated from the Welsh.

45. NLW 604D.

46. Powell, pp. 142-43.

47. Cennard Davies, "Early Free-Metre Poetry”, Gruffydd, pp. 75-99; Nesta Lloyd, "Late Free-Metre Poetry", Gruffydd, pp. 100-27; Rhiannon Ifans, "Folk Poetry and Diversions", A Guide to Welsh Literature c.1700-1800, ed. Branwen Jarvis, vol. 4 (Cardiff: U of Wales P, 2000), pp. 187-209. 
48. Phylis Kinney, Welsh Traditional Music (Cardiff: U of Wales P, 2011); Ffion Mair Jones, Welsh Ballads of the French Revolution 1793-1815 (Cardiff: U of Wales P, 2012).

49. Sarah Prescott, Eighteenth-Century Writing from Wales (Cardiff: U of Wales P, 2008); Shawna Lichtenwalner, Claiming Cambria: Invoking the Welsh in the Romantic Era (Newark: U of Delaware P, 2008); Andrew J. Davies, "'Redirecting the Attention of History': Antiquarian and Historical Fictions of Wales from the Romantic Period", Wales and the Romantic Imagination, ed. Damian Walford Davies and Lynda Pratt (Cardiff: U of Wales P, 2007), pp. 104-21.

50. Prys Morgan, The Eighteenth Century Renaissance (Llandybie: Christopher Davies, 1982); Cathryn A. Charnell-White, "Networking the Nation: The Bardic and Correspondence Networks of Wales and London in the 1790s", "Footsteps of Liberty and Revolt": Essays on Wales and the French Revolution, ed. M.-A. Constantine and D. Johnston (Cardiff: U of Wales P, 2013), pp. 143-67.

51. $B C$, no. 34 .

52. $B C$, no. 28. Jones's memorial englynion to Angharad James also praise her beauty. NLW 11993A, fol. 66, line 5.

53. James, "Merched".

54. NLW 11993A, fol. 66, lines 13-16.

55. Cardiff 84, Cardiff Central Library; BL Add. ms. 10313; BL Add. ms. 10314; NLW 11993A.

56. For Jones's indebtedness to contemporary English anthologies, see Catherine McKenna, "Aspects of Tradition Formation in Eighteenth-Century Wales", Memory and the Modern in Celtic Literatures: CSANA Yearbook 5, ed. Joseph Falaky Nagy (Dublin: Four Courts, 2006), pp. 47-50.

57. $B C$, no. 53 .

58. $B C$, no. 12, lines 9-14; trans. in Dafydd Johnston, ed., Medieval Welsh Erotic Poetry (Cardiff: U of Wales P, 1991), p. 37.

59. James, “Ann Griffiths".

60. Angharad James's manuscript is lost, but its content is listed in NLW 10257B.

61. She also transcribed the work of Margaret Rowland, Margaret ferch Evan of Cae Cyrrach and Mrs Wynne of Rhagad and others.

62. Howells, pp. 7-8.

63. Haycock, 110.

64. $B C$, no. 11, lines 1-10, 20-22; trans. in Johnston, Erotic Poetry, p. 41.

65. Howells, pp. 8-15.

66. $B C$, no. 75 , lines $93-96$.

67. $B C$, no. 77 , lines $9-12$.

68. $B C$, no. 77 , line 71 .

69. $B C$, no. 73 , lines $19,23-24$.

70. G. J. Williams, "Llythyrau at Ddafydd Jones o Drefriw", Journal of the National Library of Wales, 3 (1943): app.

71. J. H. Davies, "Margaret Davies o Goed Cae Du", Cymru, 25 (1903): 203; Williams, "Llythyrau", 39.

72. $B C$, no. 74 , lines $15-16$.

73. Lloyd-Morgan, "Oral Composition", 98-99; Powell, p. 141; Howells, pp. 4447. 
74. $B C$, nos. 35 (Marged Harri), 59 (Catrin Madryn), 60 and 69 (Angharad James), 80 and 82 (Marged Dafydd). Siân Briwtwn's poem can be found in NLW Peniarth 72, 11-16.

75. $B C$, no. 82 , lines $27-34,59-60,63-66$.

76. $B C$, no. 35 .

77. NLW 1578B, 98.

78. Dafydd Wyn Wiliam, "Sylwadau Ar Gyfrol", Tlysau yr Hen Oesoedd, 29 (2011): 16 .

79. Laura Lunger Knoppers, "Introduction: Critical Framework and Issues", The Cambridge Companion to Early Modern Women's Writing, ed. Knoppers (Cambridge: Cambridge UP, 2009), p. 7.

\section{Disclosure statement}

No potential conflict of interest was reported by the author. 


\title{
CAMBRIAN BARDS AND ANTIQUARIAN ROMANTICS: ANGLOPHONE WOMEN POETS FROM EIGHTEENTH- CENTURY WALES
}

\author{
Sarah Prescott
}

\begin{abstract}
Despite the fact that the recuperation of the ancient Welsh past at the hands of eighteenth-century "Celticists" was primarily a masculine endeavour, women poets of the time nevertheless engaged with this phenomenon on a number of intriguing levels. This essay explores a range of anglophone Welsh women poets, from the seventeenth-century Cardigan-based Katherine Philips to the Romantic writer Mary Robinson, in order to demonstrate women's engagement with antiquarian and national concerns in their own poetic productions. Through an analysis of their Wales-related poetry, which takes in a number of influences-from local knowledge of the Welsh landscape, of ancient British bardic verse, classical precedent and Welsh music, as well as the eighteenth-century "vogue" for imitating (or forging) the poetry of ancient cultures - the essay argues that it is possible to trace an identifiably female response to the period's literary interest in the ancient Celtic world.
\end{abstract}

In her poem "On the Welch Language", the seventeenth-century poet Katherine Philips laments what she sees as the decline of the Welsh language, comparing Wales to Greece and Rome in a common fall from cultural and literary greatness:

And as the Roman, and the Grecian State,

The Brittish fell, the spoyle of Time and Fate.

But though the Language hath her beauty Lost,

Yet she has still some great remains to boast;

For 'twas in that, the sacred Bards of Old,

In deathless numbers did their thoughts unfold. ${ }^{1}$

Although her knowledge is mostly gleaned from English and classical authors, not Welsh material, Philips's poem is notable in the emphasis she places on the "Bards of Old" as repositories of poetic riches and for 
the location of these Welsh bards in a pastoral framework: "In groves, by Rivers and on fertile plains". ${ }^{2}$ Indeed, her comparison of the British bards to ancient Greek and Roman culture is, claims her editor Patrick Thomas, "possibly unique in a seventeenth-century author with an English background". ${ }^{3}$ The poem then recounts a series of mythological and historical figures whom Philips claims would have spoken Welsh in addition to the bards-Merlin, Arthur, Boadicea, Caractacus/Caradoc-and who collectively represent the power of prophecy, valour, fame, liberty and honour, as shown here in the lines on Merlin:

This Merlin spoke, who in his gloomy Cave, Ev'n Destiny herself seem'd to enslave.

For to his Sight, the future time was known,

Much better than to other is their own.

And with such state, Predictions from him fell,

As if he did Decree, and not foretell. ${ }^{4}$

Philips's vision of Wales was prescient for those anglophone Welsh writers in the eighteenth century who followed her subject matter and themes. Her poem prefigures John Dyer's similar use of the Welsh/British-classical parallel in The Ruins of Rome (1740), and the poem's use of a form of national pastoral foreshadows Iolo Morganwg's vision of the Welsh-speaking bard as rustic swain in his Poems, Lyric and Pastoral (1794). Similarly, her invocation of a train of Welsh-speaking legends was to become a staple of anglophone "Cambria poems" in the eighteenth century and beyond. ${ }^{5}$ More importantly for my purposes here, and as befits the work of a poet who was the only woman writing in English from Wales in the seventeenth century, Philips's poem can also be said to adumbrate themes and approaches found in the work of women poets from Wales writing after her. This essay explores the way in which anglophone women poets from eighteenth-century Wales follow Philips's example of addressing the history of ancient Britain by engaging either directly with the antiquarian work of their male contemporaries or more generally with the historical and poetic glories of the bardic past. I aim to trace the different yet connected ways in which this engagement is achieved and to assess the contribution made by women writers to what are often seen as masculine imperatives: the antiquarian recuperation of the cultural past of the Welsh bards and the Romantic recovery of Wales as a source of poetic inspiration. ${ }^{6}$ I argue that women were engaged in a number of innovative ways with these imperatives: through the use of English and classical precedent inflected through personal knowledge of the Welsh landscape, through the direct use of bardic example and Welsh traditional song, and even through the use of forgery and/or imitations of Welsh bardic material. 
The Welsh-born poet Jane Brereton (1685-1740) is relatively unusual in the eighteenth century as an anglophone poet who consistently self-identifies as Welsh and frequently evokes the landscape of her birth. ${ }^{7}$ In an "Epistle to Mrs Anne Griffith" (written from London in 1718), for example, she looks longingly back to "our pleasant Hills" and wishes she could "breathe my native Air" ${ }^{8}$ Local place names abound in her poems, which tie them specifically to a Welsh context, and, like Katherine Philips in her wider work, her poems evoke a Welsh network of friends and acquaintances-in Brereton's case, mostly centred on Mary Myddelton's social circle at Croesnewydd and latterly the community in Wrexham and the nearby estate of Erddig. As I have previously argued, Brereton brings together her position as a woman poet and her Welsh identity as a "Cambrian Muse" whose duty it is to sing the praises of the Hanoverian succession. ${ }^{9}$ However, like Philips again, another Anglican Royalist of course, she is also indebted to classical and English precedents in her poetry, specifically in those poems which use the figure of Merlin as a further route to authorize herself as a Welsh woman poet. ${ }^{10}$ But Brereton is unusual in that her engagement with male scholarly circles brought her into close contact with some of the key antiquarians of her day, and her work consequently demonstrates direct knowledge of the history and literary past of Wales. ${ }^{11}$

My focus here is on Brereton's poem "The Dream", which is an intriguing combination of Chaucer's poetic dream vision The House of Fame and Brereton's use of loco-specific descriptions of her native locality near Mold. Appropriately, the poem opens with the author falling asleep while reading The House of Fame and, once asleep, she begins to dream. "Ungovern'd Fancy" swiftly takes over and she imagines herself waking at the site of a Roman fort in Wales:

My Reason bound in Sleep's soft Chain,

Ungovern'd Fancy strait grew vain,

Bore me, where Antiquaries found

A Roman Fort, on British Ground. (135)

Brereton very precisely locates the site of her dream in both a classical and a British/Welsh context, yet she also injects a personal feminized perspective into her description of the antiquarian landscape. As the poem develops, it becomes clear that she is imagining returning to the haunts of her childhood in Denbighshire and Flintshire, and that the Roman fort is that still situated at Moel y Gaer in the Clwydian range of mountains:

Methought, I breath'd the Ev'ning Air, Upon the summit of Mole-gare;

Much pleas'd I was, and gazing stood, 
While the Welch Hills, and Irish Flood, With various Prospects, greet my Eyes, And well-known Scenes, promiscuous rise. (135)

Brereton's Chaucerian-inspired dream then assumes a further Arthurian dimension, which is again firmly rooted in her knowledge of the landscape of her Welsh birthplace and closely replicates the view when standing on the top of the Clwydian mountains:

From thence Mole-Arthur I behold, Where the fam'd Briton sat of Old, His Four-and twenty Knights among;

(As Cambrian Bards have whilome sung)

If any at this Tale will mock,

Let them repair to view the Rock;

Where, if to count twice Twelve they're able,

They'll find the Seats of the Round Table. (136)

The use of this local context is reinforced by her references to the nearby Halkyn Mountain (one of the largest lead producers in Britain, as well as being a source of limestone): "Halkinian Hills, the Welch Pern, / Big with their Ore, rise next to view" (136). The focus then moves to another local detail: the well of the legendary St Winifred at Holywell, whose lover, Caradoc, decapitated her when she decided to become a nun. According to legend, in the place where her severed head came to rest after rolling down the hill, a healing spring was formed, which has since become a site of pilgrimage, as Brereton's poem attests:

Lo! Where fair Winifreda fell, Whose Blood produc'd a Holy Well.

Hail! Virgin Saint, may nought that's vile

Thy sacred Fountain e'er defile! (136)

At this point, Brereton's poem almost seems to forget its Chaucerian conceit in the focus on the landscape and lore of the poet's native locality, exemplified by the example of gendered violence-a legend that may have particularly caught her imagination as a woman writer.

Brereton's poem also addresses the fraught issue of female literary authority. In the proem to The House of Fame, Chaucer not only reflects on the nature and communication of fame, and its reverse, infamy, but also explores the role of the poet. In the preliminary poem to "The Dream", "Introduction to the Dream. In Imitation of Chaucer's Second and Third Book of Fame", Brereton uses this precedent similarly, but to address her role as a Welsh woman poet. Her 
opening lines betray her anxiety as a female poet emulating a prestigious male predecessor. She begs the critics to "be kind!" and asks them: "But let a Woman dream in Quiet" (131). Part of her reluctance to mimic "a Male Poet" (132) is that the basic premise of Chaucer's poem is predicated on mobility and travelalbeit a fanciful journey on the back of Jove's Eagle to the House of Famewhereas women are expected to remain within domestic confines:

Descriptions I must lay aside,

I slept, and dreamt at the Fire-side:

Tho' Men in Fields may sleep or roam,

Women had best to nap at home. (133-34)

Instead, she calls on the female Muses to help her "Dream aright, / And animate me in my Flight!" (134). Brereton's employment of this modesty trope in the preliminary verses to the main poem frames the discussion of her Welsh locality, which, in Brereton's case, was fundamental to her image, as we see in the following lines:

O'er Offa's Dyke, I haste my Sight, To view my former dear Delight;

There Alyn glides, thro' flow'ry Meads, There fertile Fields, and pleasing Shades:

Yonder the much-lov'd Spot of Earth That gave forlorn Melissa Birth! ${ }^{12}$

New crouding Thoughts my Brain opprest;

And Passions stuggl'd in my Breast:

Such Vi'lence would have broke Sleep's Chain,

If Fancy had not chang'd the Scene.

Quick, she presents old Jeffrey's Fable,

His wild Conceits, and speaking Eagle;

And a romantick scene prepar'd

To mimick that in the old Bard. (137)

Brereton, however, is a rare example of a woman poet attempting to fuse regional appreciation of her locality with a broader sense of national pride and a negotiation of her female literary authority.

Nevertheless, the mid eighteenth century witnessed a major shift in the way in which poets could tap into the poetic past as a way of authorizing their work. What we now term "Celticism" inaugurated a new flurry of interest in the historical past of Wales and Welsh literature. This broad interest in Celtic cultures received an injection of energy in 1764 when Evan Evans published Some Specimens of the Poetry of the Antient Welsh Bards, which included English prose translations of the work of a range of Welsh poets. Evans's translations 
provided an anglophone audience with direct access to the poetic past of Wales hitherto denied them. As a result of his work, it was now possible for a host of anglophone Welsh writers to engage with their Welsh-language past in ways other than general evocation of Druidic stones or references to Wales's Arthurian past. One popular method of engagement with ancient Welsh poetry was to produce versified interpretations of Evans's prose translation, and two examples by a woman can be found in Anne Penny's collection Poems, with a Dramatic Entertainment (1771): "Taliesin's Poem to Prince Elphin" and "An Elegy on Neest" (both advertised on their individual title pages as "from Mr. Evans's Specimens of the Welch Poetry"). In "Taliesin's Poem to Prince Elphin", for example, although Penny follows Evans's four stanzas, she expands his literal prose translations into rhyming couplets. Taliesin, addressing his patron in Evans's version, declaims:

ELPHIN with the lovely qualities, thy behaviour is unmanly, thou oughtest not to be over pensive. To trust in God is better than to forebode evil. Though I am but small and slender on the beach of the foaming main, I shall do thee more good in the day of distress than three hundred salmons. ${ }^{13}$

Penny's versification of Evans reads:

Elphin! fair, with Virtue blest, Let not that Virtue idly rest;

If rous'd 'twill yield thee sure relief,

And banish far unmanly Grief:

Think on that Pow'r whose Arm can save, Who e'en can snatch thee from the Grave;

He bade my Harp for thee be strung,

Prophetick Lays he taught my Tongue.

Though like a slender Reed I grow,

Tost by the Billows to and fro,

Yet still, by him inspir'd, my Song

The Weak can raise, confound the Strong:

Am not I better, Elphin! say,

Than Thousands of thy scaly Prey? ${ }^{14}$

What were seen primarily as masculine endeavours-antiquarian scholarship, bardic poetry, ancient history-are here appropriated by a woman poet as a suitable subject for the female imagination. Indeed, despite the masculine exclusivity of antiquarianism itself, the figure of Taliesin is an appropriate model for a woman writer in that it offers a feminized subject position. Taliesin is slender and tossed "by the Billows to and fro", yet also possesses lyrical and prophetic strength. More broadly, the versification of prose translations of Welsh originals was a way for women poets to engage with bardic 
culture in a creative and interpretative fashion, which contributed to the broader popularization of Celtic culture in the period.

In a further poem, "Written on PARRY's playing upon the Welch Harp", Penny continues the theme inaugurated by Katherine Philips concerning the lost glories of Welsh poetic tradition. ${ }^{15}$ In this poem, Wales is described as the "Seat once of flowing Verse, of magick Song", where the bards once haunted "Mona's Shadowy Isle". ${ }^{16}$ Penny imagines the untutored genius of Parry reanimating the dying flames of the bardic past:

Still o'er your much lov'd Cambria, still preside;

Seat once of flowing Verse, of magick Song;

Your mighty Shades the feeblest Hand can guide,

And bid their silent Harps again be strung.

Your potent Aid can fan their dying Fire,

Can call back Genius to each desart Grove;

Your Sons will rouse when you their Bards inspire,

Elate, their mighty Origin to prove. ${ }^{17}$

Penny's poem recalls Philips's emphasis on the lost glories of Welsh poetic culture: the harps are silent, the groves are like deserts, and Cambria is only the "Seat once of flowing Verse" (my emphasis). However, Penny also implies that through the power of Parry's harp-playing, "Ye Bards" return to inspire a new generation, which will rejuvenate the rich culture of Wales through the contemporary re-enactment of ancient Welsh song.

A rather less well-documented poet who also turned to the music of Wales for inspiration is Anne Hughes (c.1760-1816), who, in addition to Poems. By Mrs Hughes (1784), also published four novels. ${ }^{18}$ Little is known of her life, although her married name suggests Welsh connections, which is backed up by internal textual evidence in her poetry and her fiction. One poem in her 1784 collection shows knowledge of Wynnstay in Denbighshire, the estate of Sir Watkin Williams Wynn, 4th Baronet: "Written Extempore, upon seeing an elegant dairy house erected on that spot where a dog kennel had formerly stood, in the park at Wynstay, the seat of Sir W. W. W. Bart". Overall, the poem is a conventional pastoral, but the erection of the dairy house epitomizes the improvement achieved in the estate and a shift to a more harmonious, civilized and virtuous pastoral vision with Wynnstay at its heart. Thirses, one of the two friends who meet and note the improvements (from kennel to dairy), remarks:

The improvement affects both the heart and the sight:

For it shows, what ten thousand bright actions have shown, TRUE taste and true goodness united in one. ${ }^{19}$ 
Whereas the barking of the hounds used to scare off visitors, including the Muses themselves, now "elegance smiles, and simplicity reigns" ${ }^{20}$ The improvements to the estate symbolize Williams Wynn's attributes as a good patron who, albeit artificially, has restored a natural order on the landscape reflective of his bounty and his taste:

Instead of fierce howls, and each dissonant sound, Flocks bleat from the mountains, and herds low around;

The wood-nymphs again dance the thickets among,

And the lark and the thrush undisturb'd tune their song;

The Muses no longer are frighted away,

But have fix'd, with their Virtues, their home at Wynstay. ${ }^{21}$

Hughes's connection to Wales is further suggested by the geographical specificity of the poem "Epistle: to my beloved sister". This poem refers to the River Vyrnwy ("Whether on Virniew's fragrant banks they stray, / Perfum'd with all the sweets of new-mown hay"), ${ }^{22}$ which is near Llanymynech on the border of Powys and Shropshire on the way to Wrexham, the latter being close to the location of Wynnstay.

Descriptions of Wales also appear in her fiction. In her last novel, Jemima (1795), Captain Jones, the benevolent patriarch, appears to have had a Welsh grandmother and declares that "he had many obligations to the Cambrians". ${ }^{23}$ Jemima eulogizes the Welsh and commends their acceptance of a fall from greatness, rather than lamenting past glory:

[...] the result of her reading was, that she pronounced the Welsh the wisest, and in consequence of their wisdom, the happiest people on earth; for they trouble not themselves, said she, with political contests, and though the actual and illustrious Aborigines of Britain, as the height from which their ancestors have been precipitated is unattainable, prefer content to commotion, and tranquillity to all the fluctuating honours of greatness. ${ }^{24}$

Despite her fictional character's seeming endorsement of Welsh decline, Anne Hughes's poetry did engage directly with Welsh tradition in ways that resonate with Penny's focus on the harp as the continuation of past traditions in the present. Included in her Poems is "A Song, for the favourite Welch Air of Dafydd Garegwen":

'Twas on the Severn's sedgy margin Pensive DAFYDD chanc'd to stray;

There, on the moss-grown bank reclining,

Tun'd to the winds his careless lay.

Steepy mountains heard his murm'ring,

Echo caught the plaintive Song; 
'Mong pendent rocks the wild notes warbling, Adown the dale soft sounds prolong.

Sad his fate, whose heart, still changing,

Roves at large, and fix'd by none;

Happy he, who, free from ranging,

Fondly loves, and loves but one. ${ }^{25}$

"Dafydd y Garreg Wen" ("David of the White Rock") is a traditional Welsh air, which was supposedly composed by the harper David Owen (1711/1241) from Porthmadog in Caernavonshire, where he apparently owned a farm called Y Garregwen. According to Edward Jones, in his Musical and Poetical Relicks of the Welsh Bards: preserved by tradition and authentic manuscripts (1784), it was generally received that Dafydd composed the air while on his deathbed to be sung at his funeral:

It is a general tradition in CAERNARVONSHIRE, that a Bard of this name, lying on his deathbed, called for his Harp and performed this plaintive tune, which he desired should be repeated at his Funeral. Ever since it has been called by his name and that of CARREG-WEN, the house where he lived in that county, which still remains. Whether it was of higher antiquity, or was originally conceived by the dying Bard, is uncertain. ${ }^{26}$

Jones's third contribution to his study of ancient Welsh music, Hên Ganiadau Cymru: Cambro-British Melodies, or the National Songs and Airs of Wales (1825), includes "Dewisol Gân Dafydd o'r Garreg-Wen", which is translated as "The Choice Song of David of the white Stone in the Parish of Ynys Cŷnhaiarn, Caernarvonshire". ${ }^{27}$ In this later version, the story behind the bard is further elaborated by reference to an anecdote related by

$\mathrm{M}^{\mathrm{r}}$ Lewis Roberts, an old musician and farmer living near Tan y Bwlch; who says, that a venerable old man related to him, that he actually was at the funeral of David of Garreg-Wen, and heard the Harp play the before mentioned Melody on that solemn occasion, at the parish church of Ynys Cynhaiarn, in which parish the house called Garreg-Wen, the residence of the departed musician, is situated. ${ }^{28}$

In Relicks, however, Jones only provides the music to the air, which is described simply and appropriately as "elegaic". The words were not thought to be composed until the poet John Ceiriog Hughes (1832-87) created a Welsh version in 1873. Although Ceiriog's rendition certainly seems to be the first written Welsh interpretation of the air, earlier in the nineteenth century Sir Walter Scott published his poem "The Last Words of Cadwallon", which is presented "as written" for the air of "Dafydd y Garreg-wen" in his Miscellaneous Poems of $1820 .^{29}$ In Hên Ganiadau, Jones also included words for his first further variation of the air, which are, in fact, taken from Scott's poem mentioned above. Scott's poem rehearses many of the themes 
of anglophone Welsh-related poetry that had become commonplace by the early nineteenth century. The accompaniment of his poem with the dying words of Cadwallon, identified in a note as "a son of Rhys ab Gruffydd, prince of south Wales about A.D 1130", ${ }^{30}$ transforms the air into a celebration of national bardic resistance to Saxon invasion through the invocation of a train of ancient bards. Similarly, the harp becomes the medium of national resistance, as seen in the penultimate fifth stanza:

[...] adieu, silver Teivi! I quit thy loved scene,

To join the dim choir of the Bards that have been;

With Llywarch, and Meilir, and Merddin the old,

And sage Taliesin, high Harping to hold. ${ }^{31}$

Jones comments that the original words to the air are "lost in oblivion", adding that, this being the case, Scott's "elegant verse [...] are particularly well suited to the Air, and make ample amends for the verses lost". ${ }^{32}$

In 1784, then, it is too early for Hughes to have accessed the later lyrics to the air. The dating thus suggests that her poem is historically significant in that it could be the first written English accompaniment to the air; it certainly predates Scott. Furthermore, in contrast to Jones's use of Scott's roll call of bardic heroes, Hughes responds to the sense of the music as elegiac, suggested by its backstory as a self-composed elegy. In contrast to Scott, Hughes constructs Dafydd as a persona in the poem- "Twas on the Severn's sedgy margin / Pensive DAFYDD chanc'd to stray;"-and firmly relocates him on the banks of the River Severn. The River Severn (Hafren) has, of course, special significance for Wales, but Hughes's invocation also reflects back on the textual hints in her other poems which suggest that this is the region of Wales she was familiar with: the Welsh border between Shropshire and Powys. Thus, like Jane Brereton, she infuses her poetry on Welsh themes with what might be termed a feminine perception of the personal significance of local place. Hughes's "Dafydd" is also very much a rustic bard in that his words emerge from the landscape he roams, which, in turn, provides the backdrop and setting to his "plaintive Song". As Relicks was published in the same year as Hughes's Poems, she may have first seen the tune in this volume and been influenced by Jones's descriptions of Welsh folk music, as opposed to his lengthy descriptions of the bardic poetry of Taliesin and the Poets of the Princes. In his outline "Of the Welsh Pennillion", Jones emphasizes that the transmission of these songs is from "oral tradition" and often a product of "the poetical vein of the Welsh peasantry". ${ }^{33}$ The emphasis is thus on love rather than the martial themes of the bards. Of Welsh music in general, Jones declares:

The music, as well as the poetry, of Wales, was tinctured with its peculiar and original character by the genius of the country: they spring out of the same soil, 
deriving from its delightful vallies their soft and tender measures, and from its wild mountainous scenes their bolder and more animated tones. ${ }^{34}$

Taken in this context, I would argue that Hughes's poetic response was, in fact, much more "well suited" to the air in terms of register and content than that supplied by her famous successor. It is tantalizing to conjecture if her song had its roots in oral tradition and/or in social occasions in Wales where the air was performed. Indeed, as Jones points out, rather patronizingly, the harp became increasingly popular as a female accomplishment in the hands of "our modern female Bards", and Hughes herself shows an active interest in music in some of her novels. ${ }^{35}$ Whatever the factual truth, Hughes's poem can be seen as a rare example of an anglophone woman writer engaging with Welsh music in her poetry. ${ }^{36}$

The poetry of Mary Robinson provides a rather different example of an anglophone woman poet's engagement with antiquarian culture and the bardic past of Wales. Robinson is a well-known woman writer from the eighteenth century, but her Welsh connections, through her marriage and the birth of her daughter Maria, also a writer, in Wales, are seldom acknowledged. However, as Jane Aaron and Moira Dearnley have both demonstrated, Robinson's work shows clear signs of her Welsh allegiances, and some of her novels are not only set in Wales, but also include embedded poetry arising from the Welsh settings. In her novel Walsingham, or the Pupil of Nature (1797), for example, the Welsh titular hero is filled with hiraeth ("longing") for Glenowen, his childhood home:

But thou, dear Glenowen! canst bring sweeter pleasure,

All barren and bleak as thy summits appear;

And tho' canst boast of no rich gaudy treasure,

Still memory traces thy charms, with a tear!

The keen blast may howl, o'er thy vallies and mountains,

And strip the rich verdure that mantles each tree;

And winter may bind, in cold fetters, thy fountains,

And still thou art dear, O Glenowen! to me. ${ }^{37}$

Poems more loosely associated with Wales also repeatedly emerge in Robinson's work, although they are infrequently anthologized. ${ }^{38}$ For example, the volume edited by Robinson's daughter in 1804, The Wild Wreath, includes "The Foster Child", which features Druids. ${ }^{39}$

However, back in November 1785, Robinson had published a poem in the London Chronicle in which she explored ancient bardic culture directly, or at least that is what she imagined she was doing. The poem, "Lewin and Gynneth. A Tale", also appeared in the 1791 edition of her Poems and, subsequently, in the second volume of the 1806 edition as "Llwhen and 
Gwyneth. Written in the Year 1782" ${ }^{40}$ The later edition also included some brief explanatory notes which alluded to the original source and a tribute poem. ${ }^{41}$ On first reading, Robinson's poem appears baffling both in terms of its theme and its stated source. Moira Dearnley mentions it briefly in the context of a discussion of Robinson's "Welsh" poems, quoting the explanatory notes which were included as an endnote in the 1806 edition: Mary Robinson wrote "Llwhen and Gwyneth. Written in the Year 1782" "From Mr. John Williams's prose translation of a lately discovered Welsh Poem, preserved in the collection of Arthur Price, Esq. It is supposed to have been written by Taliesin, in Ben Batridd, A. D. 534". ${ }^{42}$ Jane Aaron goes further to explore the poem itself, characterizing it as part of a vogue for "Gothic ballads set in medieval Wales and peppered with Welsh-sounding names and doom-laden Druidic prophecies [which in] its high Romantic flavour at least had the benefit of associating Welshness with exoticism, rather than contemptibility". ${ }^{43}$ However, unsurprisingly, Aaron is rather perplexed by the names of the characters, as Gynneth/Gwyneth turns out to be a man and Lewin/Llwhen is the female in the poem, who is haunted by the ghost of her dead lover. The poem itself takes the ballad dialogue form and relates the story of Lewin, "YRGANVY's Daughter", who braves the wilds of the night to seek out her lover Gynneth, who has been incarcerated in "Lathryth" castle at the hands of "BRANWORTH, Lion of the field!". ${ }^{44}$ As she approaches the castle through the mist of the dark and cold night, she spies his form "at the lofty lattice gate" ${ }^{45}$ However, the form is not Gynneth but merely his ghost:

"I am THY GYNNETH'S GHOST, sweet maid, Avoid the madd'ning sight;

Those eyes that doated on thy charms, Are lock'd in endless night.

"This loyal heart which beat for thee, Is rent with many a wound;

Cleft is my shield, my glitt'ring spear Lies broken on the ground!

"My bones the eagle hath convey'd To feed her ravenous brood;

The savage BRANWORTH's cruel hand Hath split my purple blood. ${ }^{46}$

The poem takes the form of a dialogue, and Lewin replies, pledging to follow him to the grave; she opens the "lattice gate" and her spirit flies through. The location of the story then becomes a site of pilgrimage where travellers' tears mix with the laments of the Druids: 
Beside thy tomb the TRAV'LLER's tear

Shall join the crystal spring;

Around the solemn dirge of woe

Shall sainted DRUIDS sing; ${ }^{47}$

In a similar vein to Anne Penny, then, it would appear that Mary Robinson is versifying specimens of ancient Welsh poetry-in this case, the work of Taliesin. The title of her poem would suggest that the original is possibly "Llywelyn a Gwrnerth" in the "Red Book of Hergest". Indeed, "Llywelyn a Gwrnerth" is also a dialogue poem, but the resemblance ends there as this text concerns two penitent male saints at Welshpool in Powys. However, two entries in the Town and Country Magazine for March and June 1783 would seem to pinpoint the source of Robinson's ballad. In a letter in the March issue, a correspondent called "OXONIENSIS" sent in a prose translation of "The Lamentation of Llwarch-hen, the Bard". Oxoniensis cites "the publication of Macpherson's Ossian, and Evans's Specimens of Welch poetry" as the context within which his submission may be of interest to the "learned" reader. ${ }^{48}$ He claims to be a Welsh speaker who came across the manuscript "in the library of the Louvre in France". 49 The submission is followed up by a second "Translation from the Welsh", claiming to be by "John Williams". The letter clearly corresponds to the notes accompanying Robinson's poem as to the provenance of her copy:

THE having seen your Magazine for March, a specimen of Welsh poetry, has induced me to submit the following translation to your readers, as not unworthy their notice. To the kindness and friendship of Arthur Price, Esq; I am indebted the perusal of the manuscript, from the style of which, together with some other concerning circumstances too tedious to mention, I conclude is the composition of Taliesin Ben Beirdd, who flourished about the year 534 .

"John Williams" echoes Evans's admission in Specimens that some of the language of the early bards was too obscure to translate, but he provides the following paraphrase, which closely parallels Robinson's poem:

The subject is very poetical and pathetic. Llwen, the daughter of Yrganvy, is seeking for her captured lover Gyneth, who is confined to the castle of Llathryth. She sets out upon her journey in the night (probably to elude the observation of the enemy); upon arriving near the castle, she sees a form by the light of the moon, which she concludes is her lover, and addresses it, but finds is his spirit, which exhorts her to erect a grave in his memory, and there to sit till sorrow has broken her heart-this request the genius and ferocity of the times can only reconcile. ${ }^{50}$

Mary Robinson, then, like Anne Penny, would seem to be supplying the versification and female creativity to a literal prose translation of the ancient bards, and thus could be said to be reinterpreting Wales's cultural antiquities 
for her own time and the fashionable taste of the late eighteenth century. However, the fact that it is impossible to align any of Taliesin's productions to the above plot summary should set alarm bells ringing, although it would seem that Robinson had no awareness that the passages she was transforming into verse were themselves spurious imitations of Welsh originals. In 1785, Henry Headley (1765-88) published a miscellaneous collection of his verse as Fugitive Pieces, which included "A Dirge to the Memory of Thomas Chatterton", "The Lamentation of Llwerch-Hen the Bard, upon the Death of Gwlaith, a Welch Chief" and "Llwen and Gyneth". To the latter poem, Headley provides a note which fully confesses his part in the deception of both entries in the Town and Country Magazine:

The rage of literary imposition introduced by the publication of Ossian and Rowley, was the inducement which led the author to attempt the preceding specimens of Welsh poetry; [...] The author, therefore, with the spirit of a man who meant no harm, does not scruple to confess his former intention of deceiving-The lamentation of Llwarch-hen first appeared in the Town and Country Magazine for March 1783, in a letter signed OXONIENSIS. The author, flattered by hearing its originality talked of in the same magazine for June, published what he calls a translation from Taliesin, to which he subscribed the name John Williams, and in the preliminary fictitious account, that likewise of Arthur Price, Esq together with a correction of Mr. Evans relative to a date. ${ }^{51}$

In order to erase any doubt entirely as to Robinson's source, Headley adds:

Some short time after the publication of Llwen and Gyneth, the author was not a little surprised at its laughable effects, for upon perusing Mr. Evans's Ballads, vol III, page 143, he found the story, with some slight alterations, elegantly turned into verse by Mrs. Robinson. ${ }^{52}$

Although he acknowledges that her version is a "truly spirited paraphrase", he regrets that "she was deceived in concluding that to be original which is here publically confess'd to be spurious". ${ }^{33}$

Nevertheless, Headley included the "fictitious" poems in his own collection of poems, Poems and other Pieces (1786), where he relabels them "Imitations of Old Welsh Poetry". ${ }^{4}$ Thus, despite their spurious origins, Headley aligns himself with the vogue for evoking the productions of the ancient British past not only in terms of the publications of Macpherson or Chatterton, but also in the context of versifications of genuine examples, as seen in Penny's use of Evans. Indeed, Headley's own verses, such as his "An Invocation to Melancholy", also respond to the ancient past of Wales, which suggests that his contributions to the Town and Country Magazine were as much motivated by admiration as by mischief. "An Invocation" mixes Milton and Thomas Gray with the staples of the anglophone understanding of the Welsh literary past: 
Where Taliessin in fam'd days long past, And many a Bard, whose tuneful hand is cold, Call'd forth their fabling numbers and awoke The Lion souls of Cambria's warlike Sons; Near Teivi's haunted stream, or Menai's flood Where banks with wild embroid'ry Nature fring'd. ${ }^{55}$

In fact, Headley's poems and imitations strongly echo the admired "translations" of John Walters, which were published in 1782 and which are probably the main influence on Headley, especially the poem "Lewellin and His Bards", which features the love story of Llewelyn and Ellen against the backdrop of the Edwardian conquest. ${ }^{56}$ This may be the very poem-featuring Llewelyn as king of Gwynedd-which inspired the spurious "Lewin and Gynneth". It was into this dizzying mixture of "imitations of imitations" of ancient Welsh poetry that Robinson unwittingly fell.

Rather than dismiss Robinson's poem as the product of deception, then, it is more fruitful to view her intervention as participation in a key moment when anglophone renditions of ancient bardic poetry were becoming increasingly popular beyond the limits of antiquarian circles. Robinson's poem and her other Welsh-inflected verses are important evidence of female interest in this arena. Like Katherine Philips, she also influenced other women to become interested in the Welsh past through her work, even those who were not themselves poets. In November 1785, for example, the diarist Elizabeth Baker of Dolgellau recorded her response to Robinson's poem and transcribed it in full, explaining:

The idea of the following little Poem (beautiful by the interests of the subject, and the simple graces of its style) it seems, is taken from a Welch story of great antiquity, in the manner of Ossian, but never before appeared in verse. ${ }^{57}$

Indeed, all the women poets discussed here are remarkable in that they engaged with a culture of antiquarian recovery of the Welsh past which was otherwise strikingly male. Their examples provided the templates for the women who wrote after them and also for other eighteenth-century women poets who were not directly associated with Wales, such as Anna Seward in her popular poem Llangollen Vale (1796). ${ }^{58}$ The legacy of women such as Philips, Brereton, Penny, Hughes and Robinson is seen in the early years of the nineteenth century in the work of Mary Darwell (née Whately, 1738-1825), Lucy Aikin (1781-1864) and, most clearly, Janetta Philipps in her collection Poems (1811). ${ }^{59}$ The apotheosis of this movement for women poets is, of course, the work of Felicia Hemans in her Welsh Melodies (1832), where all the staples of the anglophone tradition are brought together, from the celebration of the Welsh harp, the evocation of the Druids and the massacre of the bards by Edward I, to versifications of the prophecies of 
Taliesin, the poetry of Llywarch Hên and the war songs of Owain Glyndŵr. The links between Hemans and her female predecessors comprise another story about Welsh women's writing which we have not yet told, but it is clear that the poets in the eighteenth century who engaged with the ancient British past on their own terms as women writers laid the groundwork for a more extensive imagining of the poetic legacy of Wales in the next century.

\section{Notes}

1. Katherine Philips, "On the Welch Language”, The Collected Works of Katherine Philips: The Matchless Orinda, Volume I-The Poems, ed. Patrick Thomas (Saffron Walden: Stump Cross Books, 1990), pp. 202-03 (lines 17-22). The poem was first printed in the 1667 posthumous edition of Philips' poems, Poems. By the most deservedly Admired Mrs KATHERINE PHILIPS (London, 1667) and was included in ms. 776, Natl. Lib. of Wales, Aberystwyth.

2. Philips, line 23. Influences include Spenser, Fletcher, Geoffrey of Monmouth, Tacitus, Cicero and especially Drayton's Poly-Olbion (1612). For a further reading of this poem, see Sarah Prescott, "Archipelagic Coterie Space: Katherine Philips and Wales”, Tulsa Studies in Women's Literature, 33.2 (2014): 5176.

3. Thomas, p. 377.

4. Philips, lines 27-32.

5. See Sarah Prescott, Eighteenth-Century Writing from Wales: Bards and Britons (Cardiff: U of Wales P, 2008), pp. 84-120.

6. All the major Welsh antiquarian societies in the eighteenth century were exclusively male (for example, the Society of Ancient Britons, the Cymmrodorion and the Gwyneddigion), as indeed was the poetic culture these antiquarians excavated and studied.

7. She was born at Bryn Gruffydd near Mold, Flintshire.

8. Jane Brereton, Poems on Several Occasions (London: Edward Cave, 1744), p. 35. Subsequent references to Brereton's poems are to this edition and given parenthetically in the text.

9. See Sarah Prescott, "The Cambrian Muse: Welsh Identity and Hanoverian Loyalty in the Poems of Jane Brereton (1685-1740)", Eighteenth-Century Studies, 38.4 (2005): 587-603.

10. See, for example, Jane Brereton, Merlin: A Poem (London: Edward Cave, 1735).

11. See, for example, her poem "On Reading some Dissertations, in the Reverend Dr Foulkes's Modern Antiquities”.

12. Melissa is Brereton's pseudonym, which evokes the prophetess Melissa from Ariosto's Orlando Furioso who leads Bradamante to Merlin in Canto III. For the ways in which Brereton uses the "Melissa" persona to further her loyalty to the Hanoverian monarchs, see Prescott "Cambrian Muse" and Bards and Britons.

13. Evan Evans, Some Specimens of the Poetry of the Antient Welsh Bards (London: R. and J. Dodsley, 1764), p. 49.

14. Anne Penny, Poems, with a Dramatic Entertainment (London: for the author, 1771), pp. 6-7. The Scottish poet Anne Bannerman (1765-1829) makes reference to Specimens in the footnotes to Tales of Superstition and Chivalry (London: Vernor and Hood, 1802). See Jane Aaron, Nineteenth-Century 
Women's Writing in Wales: Nation, Gender and Identity (Cardiff: U of Wales P, 2007), p. 50.

15. John Parry/Parri Ddall (Blind Parry) (1710?-82) was harper to Sir Watkin Williams Wynn of Wynnstay and played in London in the 1740s.

16. Penny, pp. 139, 138.

17. Penny, p. 139.

18. Her novels are Zoriada; or, Village Annals, 3 vols. (London: T. Axtell, 1786); Caroline; or, the Diversities of Fortune, 2 vols. (London: William Lane, 1787); Henry and Isabella; or, a Traite through Life, 4 vols. (London: William Lane, 1788); and Jemima, 2 vols. (London, William Lane, 1795).

19. Anne Hughes, Poems. By Mrs Hughes (London: J. Dodsley, 1784), p. 129.

20. Hughes, Poems, p. 130.

21. Hughes, Poems, p. 131.

22. Hughes, Poems, p. 38.

23. Hughes, Jemima, vol. 1, p. 132.

24. Hughes, Jemima, vol. 1, p. 132.

25. Hughes, Poems, p. 44.

26. Edward Jones, Musical and Poetical Relicks of the Welsh Bards: preserved by tradition and authentic manuscripts (London: Printed for the Author, 1784), p. 59.

27. Edward Jones, Hên Ganiadau Cymru: Cambro-British Melodies, or the National Songs and Airs of Wales (London: Printed for the Author, 1825), pp. 24-25.

28. Jones, Hên Ganiadau, p. 27.

29. Scott repeats the history behind the air with information gleaned from Jones in his Miscellaneous Poems (Edinburgh: Archibald Constable, 1820), p. 398.

30. Hên Ganiadau, p. 25, note 4.

31. Hên Ganiadau, p. 25.

32. Jones, Hên Ganiadau, p. 27.

33. Jones, Relicks, p. 30.

34. Jones, Relicks, p. 28.

35. See Jones, Relicks, p. 29. See also Pierre Dubois, Music in the Georgian Novel (Cambridge: Cambridge UP, 2015), esp. ch. 17: "Intimations of Musical Gendering: Anne Hughes, Caroline", pp. 202-09.

36. Her name and her poem do not appear in discussions of the air, and Jones was seemingly unaware of (or unimpressed with) her production, as he did not include it in Hên Ganiadau.

37. Mary Robinson, Walsingham, or the Pupil of Nature (London: T. N. Longman, 1797), 4 vols., vol. 1, p. 107 . Robinson's "Welsh" poems are mostly found in her novels. See also Mary Robinson, Poems, 3 vols. (London: 1806). Volume 2 prints this as "Farewell to Glenowen" (368).

38. Katherine Philips's "Welsh" poems are also infrequently anthologized in comparison to her other work.

39. Maria Elizabeth Robinson, ed., The Wild Wreath (London: Richard Phillips, 1804).

40. The poem cannot have been written in 1782, as will become clear.

41. "Lines addressed to Mrs Robinson. By the late John Henderson Esq. On reading a little Welsh Ballad written by Mrs Robinson entitled 'Lewin and Gwyneth"'.

42. Moira Dearnley, Distant Fields: Eighteenth-Century Fictions of Wales (Cardiff: U of Wales P, 2001), p. 234n21. Robinson obviously had no knowledge of Welsh. She means "Ben Beirdd" ("Chief Poet"), a frequent appellation for Taliesin. 
43. Aaron, p. 51.

44. Mary Robinson, Poems (London: T. Spilsbury and Son, 1791), 2 vols., pp. 220, 219.

45. Robinson, Poems (1791), p. 220.

46. Robinson, Poems (1791), p. 221.

47. Robinson, Poems (1791), p. 222.

48. Town and Country Magazine, Mar. 1783: 125-26.

49. Town and Country Magazine, Mar. 1783: 126.

50. Town and Country Magazine, June 1783: 319.

51. Henry Headley, Fugitive Pieces (London: C. Dilly, 1785), p. 22.

52. Headley, Fugitive, pp. 22-23. Thomas Evans, Old Ballads, Historical and Narrative, with some of Modern Date, 4 vols. (London: T. Evans, 1794). Robinson's "Llweyn and Gyneth" is printed as "By Mrs Robinson", vol. 3, pp. 142-47.

53. Headley, Fugitive, p. 23,

54. Henry Headley, Poems and other Pieces (London: J. Roeson, 1786), p. 47.

55. Headley, Poems, p. 8.

56. John Walters, "Lewellin and His Bards, A Dialogue", Translated Specimens of Welsh Poetry in English Verse, with Some Original Pieces and Notes (London: J. Dodsley, J. Walter, and G. Kearsly, 1782), pp. 1-8.

57. Elizabeth Baker (c.1720-99), no. 24 of loose-leaved papers, "Elizabeth Baker Papers, 1740-1798", Natl. Lib. of Wales. She copies out a poem about Robinson from 'the Star' newspaper written by 'Eugeneus', in leaf no. 86. Baker was the daughter of a clergyman from the Midlands and became secretary to Hugh Vaughan at Hengwrt after her mining venture in Dolgellau failed. It is thought that she died in Dolgellau in 1799.

58. Seward's poems in three volumes were edited by Walter Scott in 1810.

59. See Aaron, p. 202n11.

\section{Disclosure statement}

No potential conflict of interest was reported by the author. 


\title{
"LOCAL AND CONTEMPORARY": RECEPTION, COMMUNITY AND THE POETRY OF ANN JULIA HATTON ("ANN OF SWANSEA")
}

\author{
Elizabeth Edwards
}

\begin{abstract}
This article reads the poetry of "Ann of Swansea", Ann Julia Hatton (née Kemble, 1764-1838), in the context of recent scholarship that emphasizes the expansive but networked and responsive nature of Romantic-period women's writing. Building on recent research, it shows Hatton as part of a writerly community shaped by poets and novelists into what Harriet Guest has termed "a shared cultural identity forged through sociable and literary exchanges". It goes on to consider Hatton as a Welsh writer by choice rather than background or birth, claiming a place within Wales's bardic tradition through her identification with Swansea and the surrounding south coast. This article concludes with a close reading of the reception history of Hatton that offers the category of the local as a new direction within histories of women's writing and notions of literary recovery. In this way, it suggests ways of reconfiguring Romantic-period literary culture to account more fully for the work and reception of nonmetropolitan writers.
\end{abstract}

Long before Dylan Thomas became Swansea's best-known writer, Ann Julia Hatton (née Kemble, 1764-1838) was its unofficial Poet Laureate on account of a single short work, "Swansea Bay". The poem, a portrait of restless shoreline melancholy, was first published in 1811. Its reception history can be traced through the nineteenth and twentieth centuries up to Kathryn Gray's T. S. Eliot Prize-shortlisted collection The Never Never (2004), where it supplies the epigraph to a collection that depicts "a Gothic British neverland of pubs, estates, rainy streets, bedrooms, garages, cafés, and chapels".

Two centuries before Gray's evocation of Swansea's nightlife, high-rise flats and the narratives that unfold within them, Hatton used the south Wales coast and hinterland as spaces in which to explore relationships and sociability. Her two published collections, Poems on Miscellaneous Subjects (1783) and Poetic Trifles (1811), are structured by several key themes. Verses on emotional attachment, especially friendship and erotic and/or lost love, stand out in both books, as do reflections on politics and civilian life in wartime, in the 
context of the American and French revolutions. Notions of literary history, inheritance and connection, particularly those viewed from a Welsh perspective, emerge more strongly in the second collection, Poetic Trifles, which Hatton published under the pen name she would use throughout the 1810s and 1820s: "Ann of Swansea". This second collection is also notable for its discussions of social oppression (which supplies the title of the long poem set at the centre of the book) and rights in relation to race and gender.

The parallels, however, between Hatton and Gray, two Swansea poets writing at either end of two centuries, only run so far. The main aim of this article is to locate Ann Hatton/"Ann of Swansea" within the context of the women writers who were her contemporaries. It therefore reads her poetry in the light of new scholarship that emphasizes the expansive but networked and responsive nature of Romantic-period women's writing. Building on recent research, it shows Hatton as part of a writerly community shaped by poets and novelists into what Harriet Guest has defined as "a shared cultural identity forged through sociable and literary exchanges". ${ }^{2}$ It goes on to consider Hatton as a Welsh writer by choice rather than background or birth, claiming a place within Wales's bardic tradition in her identification with Swansea and the surrounding south coast. In this way, this article examines the role of the local within reception histories and in the recovery of socalled minor writers; in doing so, it suggests ways of reconfiguring Romantic-period literary culture to account more fully for the work and reception of non-metropolitan writers. ${ }^{3}$

\section{London-New York-Swansea}

The long pause between the publication of Hatton's two books of poetry in 1783 and 1811 reflects the unsettled, itinerant circumstances of her life in this period. It is also, however, characteristic of her biography as a whole, which suggests a lifelong struggle in both financial or professional and emotional terms. She was born into the Kemble family of actors in Worcester in April 1764, nine years younger than her sister, the future Sarah Siddons. Hatton is said to have suffered from childhood from a physical disability described as lameness, and to have been severely scarred by smallpox, but this was just the beginning of her misfortunes. Her early marriage to an actor known only as C. Curtis quickly turned out to be bigamous (on his part), and scandal followed scandal as she worked for the electro-sexual therapist Dr James Graham at his "Temple of Hymen" in the early 1780s, attempted suicide in Westminster Abbey in 1783, and was shot at in a Covent Garden bagnio in 1789 (probably while working as a prostitute). ${ }^{4}$ These events were all reported in the London press, but Hatton also made use of the press for her own ends, petitioning her much more successful siblings, Sarah Siddons and John Philip Kemble, for help in hard times via 
newspaper advertisements. ${ }^{5}$ The scandals, and the press coverage, apparently proved too much for the rest of the family: Siddons and Kemble offered Hatton an annuity of $£ 90$ (some sources suggest $£ 50$ ) on condition that she lived at a distance of at least 150 miles from London. Rejection from her family in this way was a source of much bitterness to Hatton throughout her life-she later wrote that "the errors and indiscretions of a girl of sixteen did not deserve so long a life of abandonment"- but the annuity enabled her to marry William Hatton, a London violin maker, in $1792 .{ }^{6}$

The couple emigrated to New York later that year, in a move that marked a turning point for Hatton as a writer. Within weeks of arriving there, she began placing her poetry in local newspapers and periodicals, writing verses that aimed to "attract New York's French Revolutionary sympathizers and to lend her support to democratic-republican operatives as political allies"? These pieces duly attracted the attention of those in literary and political clubs, such as Richard Bingham Davis, who helped Hatton bring her libretto for Tammany, or the Indian Chief-an opera on Native American themes-to the stage in March $1794 .{ }^{8}$ Her performance of her own odes on the capture of Toulon and the Fourth of July before the Democratic Society of New York around the same time also attests to her participation in local pro-revolutionary circles. ${ }^{9}$

These occasional works were not her first publications, and Hatton had signalled her willingness to write about public affairs in her debut collection, Poems on Miscellaneous Subjects. This book opens with a poem on the Peace of Paris-the treaty that formally ended the American wars in September 1783 with the loss of Britain's 13 colonies-aligning Hatton with contemporary women who were critical of the war such as Anna Seward in her Monody on Major André (1780) and Helen Maria Williams in An Ode on the Peace (1783). Hatton discusses the Peace, depicted as a female figure mourning on the shoreline, via a series of British army and naval figures, who embody both "the horrors of a War; which has robbed England of so many bright ornaments" (Major John André, Lord Robert Manners) and personal bravery on an epic scale (General Elliot, Admiral Rodney), despite an outcome widely viewed as a national disaster and disgrace. ${ }^{10}$ Like Mary Robinson in her debut poetry collection of 1775, Hatton dedicated Poems on Miscellaneous Subjects to the socialite and Whig campaigner the Duchess of Devonshire. Although she also tried to trade on her Siddons connection in the book's subtitle, and again in its preface ("the Author is apprehensive, too much will be expected from one who is so nearly related to Mrs. Siddons"), Hatton's oppositional sympathies were evident from her earliest writings. ${ }^{11}$

Leaving New York on the outbreak of yellow fever in 1799, the Hattons moved first to Nova Scotia and then returned to Britain, settling in Swansea. ${ }^{12}$ At the turn of the nineteenth century, Swansea, on the south 
coast, was Wales's "second most populous town" with over 6000 inhabitants, and an increasingly vibrant space on account of its developing sociability, in the form of clubs and societies and the theatre, and its tourist industry, especially sea bathing. ${ }^{13}$ Here, the Hattons kept a bathing house (apparently with limited success) until William Hatton's death in 1806, after which Ann Hatton moved some 20 miles west along the coast to Kidwelly. ${ }^{14}$ She advertised plans for a new school in the local press, but, as in New York, she also turned to the press to fashion a new identity through her poetry. Verses signed "Ann of Kidwelly" were first published late in 1806 in the Swansea newspaper The Cambrian (founded in 1804), and appeared at regular intervals through $1807 .{ }^{15}$ Echoing her New York print exchanges, her readers replied with poems signed from London and Bath that were published in the same paper, although, unlike in New York, there is no evidence that these interactions led her to a place in local associational life.

Hatton was, however, now writing at a different point in the French wars, and in a changing literary marketplace. She returned to Swansea before 1810, when she published her first novel, Cambrian Pictures; or, Every One Has Errors, under the pen name "Ann of Swansea". ${ }^{16}$ She would publish under this name for the next 20 years, in a career mainly spent writing fiction for the Minerva Press up until 1831 when a later imprint of the press, A. K. Newman, published her final work, Gerald Fitzgerald; An Irish Tale. ${ }^{17}$ Hatton's career as a novelist is a sizeable topic beyond the scope of this article, although the currently emerging scholarship on popular and middlebrow fiction of the Romantic period suggests that it may have found its moment. It has been little noticed, however, that in this period the trope of domestic tourism from Scotland to Wales, Ireland to the Lake District, the West Country or the south coast, repeatedly patterns fiction-perhaps especially so-called popular fiction-written by women, in ways that creatively document the "interactions between shifting centres and peripheries within the British Isles". ${ }^{18}$ In this way, novels such as Hatton's reveal their tacit links to forms recovered and valued higher in recent criticism, such as the national tale.

\section{Poetic Trifles and a virtual social network of sentiment}

When she published her second poetry collection, Poetic Trifles, in 1811, Hatton looked not to the London literary trade, as she had when publishing Cambrian Pictures the previous year, but to Ireland. She referenced her "Ann of Swansea" identity and her 1810 novel in the book's subtitle, but it was printed in Waterford in south-west Ireland, a publishing centre with no known connection to Hatton beyond the Swansea-Waterford sea route. That it was perhaps unexpectedly published in Ireland, however, reflects some of the displacements and mobility or fluidity of the book as a whole, 
as well as suggesting that it had a different status, and aimed at a different readership, from her London-issued fiction. Poetic Trifles is a substantial work at 387 pages, and it was probably composed over a long period of time. For this reason, it is impossible to date individual pieces within the collection, aside from those first published in local newspapers, some of which appeared with a composition date. Given the long gap in Hatton's publication record, however, it seems reasonable to suggest that some of the poems published in 1811 were written long before then, perhaps in the 1790s, and that they may be read alongside contemporary poetry circulating in this period. The following section of this article therefore locates Hatton's work within the wider context of poetry by women from the 1790s onwards, particularly Charlotte Smith, whose work she could hardly not have known given Smith's prominence in late eighteenth-century British writing.

Poetic Trifles is a wide-ranging work, comprising poems inspired by her Atlantic travels ("Nova Scotia"), poems on the pleasures and pains of love ("Sonnet to Love", "Impromptu to-", "The Confession"), landscape and place ("Swansea Bay", "Lines Wrote on Penbray [sic] Mountain"), social justice ("Oppression") and contemporary life in an age of war ("Lines to the Officers of the Royal West Glamorgan Regiment of Local Militia"), as well as elegies, odes and verse epistles. Although Hatton does not use specific dates, as Charlotte Smith does in her long poem The Emigrants (1793), the time-bound, occasional nature of some of these verses-such as "Monody on the death of a Young Officer belonging to the Royal Western Glamorgan Rangers" or "Lines to-, suggested by a Rose Tree recovering, that was supposed to be dead"-gives the collection as a whole an impression of what Harriet Guest, describing The Emigrants, has called a "chronology of affective responses". ${ }^{19}$ Hatton's collection, that is, reads as a sequence of emotional events or reflections framed by personal and political affairs.

It also reads as a work framed by poetic community in more direct ways than her earlier Poems on Miscellaneous Subjects. Among the occasional pieces structured by sentiment is "Answer to Him, who marked for my particular observation 'La Rose Fletrie' of Miss Owenson”, a rhapsodic reworking of a poem published by Sydney Owenson in The Lay of an Irish Harp; or Metrical Fragments (1807). The theme of both poems is past love symbolized and memorialized by a withered rose-an image that may represent Ireland withering under colonialism-but Hatton's version is looser, more circuitous and conversational, than Owenson's. ${ }^{20}$ However, Owenson's importance for Hatton extends beyond this poem, since the "Preface" to Poetic Trifles shows her raising the issue of her positionality within a community of writers that specifically includes her Irish contemporary:

When many of these poems were written, their Authoress had never seen Lord STRANGFORD's elegant Translation of CAMOENS, nor the beautiful METRICAL 
FRAGMENTS contained in Miss OWENSON'S "LAY of an IRISH HARP." Should anything, therefore, like imitation appear, except when acknowledged, she begs leave to declare such similarity the mere effect of chance. ${ }^{21}$

Yet Hatton's protests against being read as belated, as copying the plaintive, lovesick aesthetic of Lord Strangford's 1803 translation of a sixteenthcentury Portuguese poet, or Owenson's romantic nationalism, ironically emphasize these earlier examples. Her disclaimer prompts us to read her collection as in some way continuous with these works (perhaps not coincidentally, both by Irish writers), and to locate her work at the intersection of emotion and national consciousness.

Harriet Guest has recently argued that women readers and writers developed a "commonality of feeling" and "shared imaginary" in the 1790s-a phenomenon that drew much of its energy from the figure of Mary Wollstonecraft in particular. ${ }^{22}$ Constituted by a range of literary exchanges, from poems to prefaces and private correspondence, this process connected those who Mary Robinson characterized as congenial minds across time and space. $^{23}$ This approach is especially revealing in the case of Ann Hatton. Even more than Owenson, who Hatton clearly recognized as a close contemporary in more ways than one, the key literary forerunner for Poetic Trifles is the work of Charlotte Smith. Half a generation older than Hatton, Smith published her first collection, Elegiac Sonnets, and Other Poems, a year after her in 1784. Unlike Poems on Miscellaneous Subjects, however, Elegiac Sonnets became one of the defining literary works of the end of the eighteenth century: Sarah Siddons would be among the 815 subscribers to the fifth edition of $1789 .^{24}$ Few writers would manage to replicate Smith's creative and commercial success, but they could engage with, even trial for themselves, her distinctive aesthetic. The attempt would create, in Guest's terms, a virtual social network configured by sentiment.

Smith's sonnets on painfully endured distress, on landscapes and flowers, or written as addresses to specific individuals all find ready parallels in Poetic Trifles. So do her best-known poems set on rocky cliffs or on the shorelinethe pose that would come to be synonymous with Smith not least as a result of Thomas Stothard's illustrations for Elegiac Sonnets. ${ }^{25}$ It is, then, perhaps no coincidence that "Swansea Bay", the poem that sustained Hatton's reputation as a poet over two centuries, shows this particular pose, and the process of developing a "shared imaginary", in action. The first three stanzas of the poem are characteristically Smith-like, setting out a weakly lit scene of seashore plaint:

In vain by various griefs opprest,

I vagrant roam devoid of rest,

With aching heart, still ling'ring stray 
Around the shores of Swansea Bay.

The restless waves that lave the shore,

Joining the tide's tumultuous roar;

In hollow murmurs seem to say -

Peace is not found at Swansea Bay.

The meek-eye'd morning's lucid beam,

The pensive moon's pale shadowy gleam,

Still ceaseless urge-why this delay?

Go, hapless wretch, from Swansea Bay. ${ }^{26}$

The emotional narrative of this poem, as in related works elsewhere in the collection such as "A Walk on the Sands" and "Evening Address to the Seagull", is steadily downbeat despite its restlessness, presenting an apparently unbreachable form of suffering or melancholy.

In the light of Harriet Guest's argument, it is striking how many women writers, well known and obscure, use this language of seashore plaint. In its longer eighteenth-century context, this mode is probably most immediately drawn from passages in James Thomson's Winter (1726). But in the 1780s and 1790 s, Smith became identified with melancholy seaside poetry to the extent that her style was also easily parodied: she became the specific target of mock seaside melancholy in the Morning Post in January $1790{ }^{27}$ Anna Seward and Helen Maria Williams, however, produced powerful versions of the Smith pose in the 1790s in, respectively, "Sonnet [On the damp margin of the sea-beat shore]" and "Sonnet: To the Curlew" (which opens with the line "Soothed by the murmurs on the sea-beat shore"). ${ }^{28}$ In 1808 , the little-known (but perhaps Welsh-sounding?) poet Susan Evance published some of the period's most recognizably Smith-inspired versesamong them, "To Melancholy", "Written on an Eminence Over-hanging the Sea" and "Written Near the Sea". Claire Knowles has argued that Evance's work should be set in a speculative tradition of women's poetry running from Smith to Letitia Landon, Elizabeth Barrett Browning and, eventually, Sylvia Plath, in which feminized distress "opens a space for women within both high culture and an emergent mass culture". ${ }^{29}$ Unlike the narratively static closing lines of many of Smith's sonnets, or Hatton's poems, the final couplet of Evance's "To Melancholy" vividly suggests that kind of opening: "My raptur'd spirit soars on wing sublime / Beyond the narrow bounds of space or time!"30 Evance's conclusion perhaps represents another effect of engaging with the Smith pose, in which agitated melancholy (to use her terms in the poem) may transcend its apparently "narrow bounds". 


\section{Ann-of Swansea?}

Susan Evance's use of the sonnet form arguably closes the gap between her own poetry and that of Smith, at least by comparison with Hatton, whose links to Smith appear to be made more at the level of content and mood rather than poetic technique. In this way, Smith is less an artistic ideal for Hatton than a writer whose work has opened up pathways into a public world of letters, and an increasingly well-defined literary marketplace. There are, however, other connections between Hatton and other writers who are explicitly concerned with Wales.

One of the lines of connection between Hatton and Smith runs directly through Swansea-Hatton's adopted home and place of banishment, with which she identified herself, like a medieval matriarch, as "Ann of Swansea". In Smith's 1788 novel Emmeline: or The Orphan of the Castle, Swansea is liminal, marked out as a place in which to live relatively obscurely or quietly, as the character Mrs Stafford (one of Smith's fictional self-portraits) observes: "I might indeed have gone to Weymouth or some nearer place; but I wish to avoid general company". ${ }^{31}$ The sense in which visitors to Swansea could remain anonymous if they chose to appears to be confirmed by the circumstances surrounding the suicide of Mary Wollstonecraft's elder daughter, Fanny Wollstonecraft, in Swansea's busy Mackworth Arms in October $1816 .^{32}$ However much south Wales was growing in popularity with tourists in this period, then, it could still seem relatively off the map. Beginning with contemporary perceptions of Hatton's location as provincial and remote, the next section of this article considers her as a Welsh writer by election, bringing out some of the nuances of her identification with Wales in general and Swansea in particular.

Earlier in 1816, Hatton had satirized contemporary Swansea society in her novel Chronicles of an Illustrious House: or, The Peer, the Lawyer, and the Hunchback; a Novel, a work that skewers locals and tourists alike, but whose "most malign characters" are, as Jane Aaron points out, "not so much the deluded townspeople but their elite visitors, who have constructed and made fashionable the sophisticated corruptions the townspeople ape, only then to scorn them for their attempts at mirroring such vices". ${ }^{33}$ Hatton's hostility to Swansea society in general perhaps gestures towards the doubleness of her experience of the town as both enabling - creatively and professionallyand confining. In her efforts to remake herself as a Welsh writer, however, it is not just Swansea, but Wales in general that resonates in her poetry.

Several of her works show her engaging with Wales's bardic tradition, as in the Gothic-medievalist "Kidwelly Castle", where the speaker of the poem contemplates the ruined castle at night and begins to search through Welsh military and literary histories, relating them to her own practice as a poet: 
Where sleeps thy sounding harp, oh, Cambria! tell?

Which erst thy druids swept with so much art;

Silent amidst thy woods, the tuneful spell

Vibrates no more upon the feeling heart.

[...]

One less energic now presumes to sing,

Since proud Aneurim's [sic] magic sounds are o'er,

To simpler notes attuned the trembling string,

Raising the sullen echoes of thy shore. ${ }^{34}$

The melancholy tenor of this piece is typical of Poetic Trifles as a whole, and yet it stands out within the collection for its exploration of the culturally embedded condition of the poet. Catherine Brennan has argued that Hatton's serial experience of dispossession (her loss of her reputation, her family, her partners, or identities linked to places such as England or America) finds powerful expression in the context of Wales because her situation is that of "an exiled poet in a colonized country". ${ }^{35}$ A portrait of the Welsh bard stripped of his position as the mouthpiece of society and the guardian of collective memory, now confined to its precarious margins though not stripped of his creative power, frames the longer poem "Hoel's Harp", first published in Cambrian Pictures. "Kidwelly Castle" goes further, depicting the "loss of Wales's poets as both symptom and partial cause of [its] political decline" ${ }^{36}$ In this poem, minstrel song is confined to "dark oblivion", while the ruins of the castle that dominates the small town of Kidwelly represent a monument to lost or faded glory.

Such images of Wales bring the correspondences between Hatton's writing and the elegiac nationalism of Owenson's Lay of an Irish Harp into clearer focus. They also illustrate the double-edged nature of Hatton's Welsh identity. The material and historical contexts give her permission to become a writer in the Welsh tradition ("One [...] now presumes to sing"), though the prevailing themes are those of silencing and loss. Catherine Brennan has suggested that Hatton's iconic "Swansea Bay" depicts life in Wales as captivity; bounded by the shore and stubbornly rhythmic waves, "Swansea Bay itself represents the very edge of her emotional imprisonment; its breaking waves symbolize the narrowness of her confinement, the ocean beyond the tantalizing freedom she is denied". ${ }^{37}$ Persuasive though this reading is, it misses the extent to which Hatton is also exploiting the bereft emotional landscape of the shoreline, as poems such as "Swansea Bay" or "A Walk on the Sands" key into wider networks of sentiment and "liberal sociability". ${ }^{38}$ It is not clear how far Hatton herself recognized or sought out such networks between contemporary women poets. But identifying them establishes her not as an isolated, provincial footnote to Romantic literary culture, but as a prolific and engaged 
participant within a much larger system of exchange, commentary and response-one that is still expanding from a critical perspective.

\section{Always "local and contemporary"}

The discussion above has outlined a more levelled map for Romantic-period women's poetry, in which literary dialogue through a combination of correspondence and publication (in volume form, but also in new periodicals and provincial newspapers) becomes increasingly possible through time. The final section of this article takes up the question of literary recovery, and takes a closer look at the role of the local within the wider reception history of Ann Hatton. It shows that, from a local perspective at least, she has always been recognized as a significant figure, and suggests that the fluid, inclusive model of community proposed by Harriet Guest both resists the oversimplifying or distorting effects of recovery and canon (re)formation, and creates new pathways for interpreting lesser-known writers. It suggests that going "beyond recovery" in this way also makes space for non-metropolitan practices and perspectives, such as the careers of Welsh women writing in either of the languages of Wales.

Recent developments in the field of literature and place are too broad and varied to summarize here, but a couple of contrasting approaches will illustrate the enduring nature of the impact of where an author writes on what, and on how, she writes, as well as on how it will be received. Fiona Stafford has recently made the case that because poetry "is conditioned by its original location, wherever that may be", the local has no less a claim to the universal than anywhere else. ${ }^{39}$ Her argument validates any and every point on the levelled map, though not everyone will agree; the opposite view may be seen in Murray Pittock's earlier caution against making "facile gesture[s] towards inclusion" in reaching for the "neutral" and "plural" in British romanticisms. ${ }^{40}$ Pittock also, however, stresses that the study of romanticism has suffered from critics' concentration on "monolingual norms and national traditions", which may also have contributed to the forgetting of "Ann of Swansea", and which may be a reason to read her now. ${ }^{41}$ New readings of the local as a distinct approach are also currently emerging. In an article on the Northampton labouring-class poet Mary Leapor, Anne Milne has challenged critics to rethink the relationship between canonicity, place and the local, concluding that:

How broadly to entertain Leapor's local culture in reading her work becomes the "new direction" to pursue, extending skepticism beyond what works are excluded or need to be included. It investigates how the institutions of "great literature" are valued and promoted, as well as whether canonicity as an institution denigrates local cultures. ${ }^{42}$

Milne's study balances Leapor's "homelessness" (her sense of alienation within her locality) with her "place-making" in ways that parallel Hatton's 
experience of the dialectic between exile/displacement and locatedness in Swansea. ${ }^{43}$ This decentred approach draws on new developments in ecocriticism in particular, but may also be seen as a regional extension of recent moves towards the study of transperipheral exchanges, mentioned above. ${ }^{44}$

A long view of the career of Ann Hatton, and the extent to which she may or may not need "recovery", suggests that there are numerous ways of being "local and contemporary". In August 1894, a contributor to the South Wales Daily Post, signing under the name "Breosa", began an article on Hatton with claims for her obscurity and provinciality:

The name of Ann Julia Kemble, or "Ann of Swansea" as she called herself in her writings, is almost forgotten, except by the students. The little fame she achieved was entirely local and contemporary, and she was overshadowed by her sister, the divine Sarah Siddons, and her brother John Kemble. ${ }^{45}$

The column rehearses all the standard facts about Hatton, but representing her as "almost forgotten" is unusual in the late nineteenth century. For example, another piece from 1894, on Swansea as a changing civic space, calls her "the famous Ann of Swansea", while "Swansea Bay" was referenced in a letter protesting against pollution in the town, and particularly on the beach, in 1878 :

Swansea Bay, and its margin of bright yellow sand, are a subject that has evoked the admiration of many a speaker and rhymester, both before and since Mrs. Hatton (Ann of Swansea) mingled her rhythmic plaints with the murmur of the waves. ${ }^{46}$

In 1910, she appeared in a passage reflecting on the place of the arts in heavily industrialized settings such as those of south Wales:

A town recollects its artists when its merchant princes have dropped into oblivion. Look at the case of Swansea. Of whom are we always boasting? Not the men of metal, who have poisoned our rivers, blasted our hillsides [...] but Walter Savage Landor, old Deffett Francis, and even poor old Ann of Swansea. They're the people we like to trot out for inspection before the world.

The conclusion of this passage advises the neighbouring industrial town of Llanelli to support its artists-"If Llanelly [sic] wants to make its mark in the world, it must cultivate something else besides being 'on the make' of tinplates and coin of the realm"-and shows Hatton's place in Welsh cultural memory as not just enduring but unexpectedly current: the point speaks as much to debates about the value of the arts in the 2010s as the 1910s. ${ }^{47}$

Hatton remains Swansea's contemporary. In 2014, she was commemorated via a blue plaque, mounted on Swansea's Civic Centre, built on the site of the Hattons' bathing house. ${ }^{48}$ The idea of a public memorial, however, dates back at least to the late nineteenth century. It was raised, for example, in 1888, in an account that reflected on the historically contingent nature of writerly fame, 
and suggested that Hatton would have been much more successful in a later literary marketplace, as were the novelists Allen Raine and the Swansea-based Amy Dillwyn:

Our valued friend, "Ann of Swansea," was unquestionably a great genius, and Swansea has reason to be proud of the name she assumed. Had she lived 100 years later, judging from the numerous successful publications now-a-days, she would have met with a very different reward. And this reminds me of having suggested to you the propriety of having a circular tablet inserted in the house in Park-street, where she lived and died. ${ }^{49}$

Other local celebrations of "Ann of Swansea" included naming a street after her: Kemble Street, in the new suburbs to the west of the town, as mentioned in The Cambrian in $1892 .{ }^{50}$ A century after its first appearance, "Swansea Bay" featured as a byword for the town, and a talisman for its people abroad, in an article on local history: "The beautiful lines of 'Ann of Swansea' were something for Swansea folk sojourning in London to remember". ${ }^{1}$

In 1932, Dylan Thomas characterized Hatton as "the first local writer of anything approaching importance", observing that-though he did not think much of her poetry- "[s]he was the first writer to link Swansea with the rest of the literary world". ${ }^{52}$ Unlike nineteenth-century commentators, Thomas jumbles her life story, in a passage that curiously anticipates his own ill-fated trips to New York in the 1950s, but which also suggests that the cultural figure was more important than the scandalous biography:

Ann Kemble, then Ann Hatton, decided to live in New York, and stayed there, trying to drown her troubles in the fashionable gaiety and snobbery of the time until she heard of her husband's death. She came back to Wales and later married Mr. Curtis, with whom she lived for the rest of her life. ${ }^{53}$

It is not surprising that Thomas should have known about Hatton, given that he grew up no more than half a mile from Kemble Street. But she also appears in the archives in more unexpected places, such as the commonplace book kept by Jane Jones of Llandeilo between 1810 and 1853. By far the most copied poet in Jones's book is Robert Burns, whose verse epistles, prayers and poems, subtitled "A Dirge" ("Man was made to Mourn" and "Winter"), capture the themes of suffering, friendship, longing, resignation, death and religious devotion that emerge across the manuscript as a whole. Among verses copied from Mary Robinson, William Wordsworth, John Clare and Letitia Landon is Hatton's predictably dark poem "To a Raven", attributed by Jones to "Julia of Swansea". ${ }^{44}$ The attribution suggests that she may have encountered the poem in a newspaper, rather than in Poetic Trifles, but either way the manuscript adds another strand to Hatton's reception history and wider community of readers and writers.

If Ann Hatton moved outwards, towards metropolitan taste and publishers in her work for the Minerva Press, so her work also circulated within different 
Welsh contexts, from Swansea's nineteenth-century anglophone press to the predominantly Welsh-speaking rural community of Llandeilo. It is possible to map the emotional trajectories of Hatton's Swansea writing career onto real spaces, which become particularly (but not exclusively) intelligible from a local perspective. At the same time, her poetry aspires to wider sociable and sentimental connections. Combining the two trajectories results in a case study of the ways in which being local and/or contemporary is not necessarily to be bound by place or time after all.

\section{Notes}

1. Zoe Brigley, "Notes for Broadsheet Poets 19. Part 2: Social Anatomists", Agenda, 46.4 (2012): 96-105 (95).

2. Harriet Guest, Unbounded Attachment: Sentiment and Politics in the Age of the French Revolution (Oxford: Oxford UP, 2013), p. 122.

3. Laura J. Rosenthal discusses the historically contingent nature of the women's writing recovery project, and advocates approaching it with increased critical detachment. Laura J. Rosenthal, "Recovering from Recovery", The Eighteenth Century, 50.1 (2009): 1-11.

4. The fullest biography of Hatton can be found in Jim Henderson, "Ann of Swansea: A Life on the Edge", National Library of Wales Journal, 34.1 (2006): 1-47. For the view that Hatton became a prostitute following the collapse of her marriage to Curtis, see "Ann Julia Hatton", Orlando: Women's Writing in the British Isles from the Beginnings to the Present $<\mathrm{http}: / / o r l a n d o$. cambridge.org/public/svPeople?person_id=hattan>.

5. Henderson, 12.

6. Unpublished letter to John Payne Collier, c.1830s; qtd. in Henderson, 8.

7. Andrew L. Hargroder, “'A Circle Form'd of Friends': Candor, Contentiousness, and the Democratic Clubs of the Early Republic", Master of Arts thesis, Louisiana State U, 2015, p. 41.

8. Hargroder, pp. 2, 70-71. Robb K. Haberman shows that Hatton and Davis's poetic exchanges were "strengthened through associational affiliations". Robb K. Haberman, "Magazines, Presentation Networks, and the Cultivation of Authorship in Post-Revolutionary America", American Periodicals, 18.2 (2008): 141-62 (145). For a discussion of the radical themes of Tammany, see Jane Aaron, "The Rise and Fall of the 'Noble Savage' in Ann of Swansea's Welsh Fictions”, Four Nations Fiction, ed. Elizabeth Edwards, spec. issue of Romantic Textualities: Literature and Print Culture, 1780-1840 (forthcoming).

9. Philip H. Highfill, Jr., Kalman A. Burnim, and Edward A. Langhans, eds., A Biographical Dictionary of Actors, Actresses, Musicians, Dancers, Managers, and Other Stage Personnel in London, 1660-1800, vol. 7 (Carbondale: Southern Illinois UP, 1982), p. 173.

10. Ann Curtis, Poems on Miscellaneous Subjects: by Ann Curtis, Sister of Mrs. Siddons (London: printed for the author, 1783), p. vii.

11. Curtis, p. v.

12. Henderson, 17.

13. Louise Miskell, Intelligent Town: An Urban History of Swansea, 1780-1855 (Cardiff: U of Wales P, 2006), p. 3. 
14. For the financial difficulties involved in running the bathing house, and the Hattons' repeated appeals to John Kemble for help, see Henderson, 20-21.

15. See, for example, the following poems from The Cambrian: "To Lorenzo", 17 Jan. 1807; "For the Cambrian", 14 Feb. 1807; "To Lorenzo", 23 Feb. 1807; "Sonnet to the Virginian Hyacinth", 21 Mar. 1807; "Imitated from Petrarch", 4 Apr. 1807; "Elegy on an Old Wig”, 6 June 1807; “To [illegible]", 18 July 1807; "To Mariane", 31 Oct. 1807.

16. Hatton's previous pen names - "Ann of Kidwelly" and "Julia of Swansea"-are pointed out in an advertisement for Cambrian Pictures in the Carmarthen Journal and South Wales Weekly Advertiser, 28 July 1810.

17. First published in London by E. Kerby in 1810, Cambrian Pictures was reissued by the Minerva Press in 1813.

18. Juliet Shields, "Situating Scotland in Eighteenth-Century Studies", Literature Compass, 9.2 (2012): 140-50 (143). The forthcoming special issue, Four Nations Fiction, reveals some of these interactions via studies of the work of novelists including Sydney Owenson, Catherine Hutton, Jane Austen and Anna Eliza Bray.

19. Guest, p. 23.

20. Terence Allan Hoagwood, From Song to Print: Romantic Pseudo-Songs (Basingstoke: Palgrave, 2010), pp. 55-56.

21. Ann Hatton, Poetic Trifles, by Ann of Swansea (Waterford: Printed for the author, 1811), p. v.

22. Guest, p. 13.

23. Guest, pp. 83-84, 93.

24. Charlotte Smith, Celestina, ed. Loraine Fletcher (Peterborough, ON: Broadview, 2004), pp. 21-22.

25. Fletcher, pp. 23, 25.

26. Hatton, Poetic Trifles, p. 58.

27. Claire Knowles, "Hazarding the Press: Charlotte Smith, the Morning Post and the Perils of Literary Celebrity", Romanticism, 20.1 (2014): 30-42.

28. Andrew Ashfield, ed., Romantic Women Poets, 1770-1838 (Manchester: Manchester University Press, 1995), p. 77. For Seward's sonnet, written in 1790 but not published until 1799, see pp. 3-4.

29. Claire Knowles, Sensibility and Female Poetic Tradition, 1780-1860: The Legacy of Charlotte Smith (Aldershot: Ashgate, 2009), p. 42.

30. Paula Feldman, ed., British Women Poets of the Romantic Era: An Anthology (Baltimore: Johns Hopkins UP, 1997), p. 242.

31. Charlotte Smith, Emmeline, the Orphan of the Castle, ed. Loraine Fletcher (Peterborough, ON: Broadview, 2003), p. 81. I am grateful to Caroline Franklin for bringing the example of Emmeline to my attention.

32. For an account of how William Godwin and Percy Shelley may have rushed to Swansea to hush up the suicide and conceal Wollstonecraft's identity, see Janet Todd, Death and the Maidens: Fanny Wollstonecraft and the Shelley Circle (London: Profile, 2007).

33. Aaron, "Rise and Fall".

34. Hatton, Poetic Trifles, pp. 68-69.

35. Catherine Brennan, Angers, Fantasies and Ghostly Fears: Nineteenth-Century Women from Wales and English-Language Poetry (Cardiff: U of Wales P, 2003), p. 55.

36. Brennan, p. 57. 
37. Brennan, p. 60.

38. Guest, p. 87.

39. Fiona Stafford, Local Attachments: The Province of Poetry (Oxford: Oxford UP, 2010), p. 1.

40. Murray Pittock, Scottish and Irish Romanticism (Oxford: Oxford UP, 2008), p. 8.

41. Pittock, pp. $10-11$.

42. Anne Milne, "The Place of the Poet in Place: Reading Local Culture in the Work of Mary Leapor”, Tulsa Studies in Women's Literature, 34.1 (2015): 125-39 (137).

43. Milne, 128-29. It is worth pointing out that both writers were known for writing satires on local subjects.

44. Milne uses "bioregionalism", an environmental movement that seeks "to combine traditional agrarianism with more radical social ecological or anarchistic leaning [and to] promote decentralisation of the economy, in the form of regional diversification and self sufficiency", in order to open up new approaches to the local (125).

45. "Breosa", "Ann of Swansea", South Wales Daily Post, 23 Aug. 1894. A second column focusing on Hatton's writing (rather than her biography) was published in the same newspaper on 30 Aug. 1794, titled "A Swansea Poet".

46. See, respectively, South Wales Daily Post, 31 July 1894 and The Cambrian, 24 May 1878.

47. South Wales Daily Post, 7 Nov. 1910.

48. See "Ann of Swansea (Ann Julia Hatton née Kemble)", City and County of Swansea, <http://www.swansea.gov.uk/article/11876/Ann-of-Swansea-AnnJulia-Hatton-nee-Kemble>.

49. The Cambrian, 13 Apr. 1888. The question of a memorial plaque for Hatton appears again in The Cambrian, 12 Sept. 1890.

50. The Cambrian, 18 Mar. 1892.

51. Cambrian Daily Leader, 20 Mar. 1914.

52. Walford Davies, ed., Dylan Thomas: Early Prose Writings, (London: J. M. Dent, 1971), p. 100.

53. Davies, p. 101.

54. Jane Jones, commonplace book, ms. 524C, fols. 55-56, Natl. Lib. of Wales, Aberystwyth. For the published poem, see Hatton, Poetic Trifles, pp. 224-26.

\section{Disclosure statement}

No potential conflict of interest was reported by the author. 


\title{
"AT ONCE ILLOGICAL AND UNFAIR": JANE WILLIAMS (YSGAFELL) AND THE GOVERNMENT REPORT ON EDUCATION IN MID NINETEENTH-CENTURY WALES ${ }^{1}$
}

\author{
Gwyneth Tyson Roberts
}

\begin{abstract}
Civil unrest in Wales during the first half of the nineteenth century was of great concern to the government in London; teaching the Welsh working classes loyalty to the Crown and the Anglican Church was the obvious answer. Accordingly, three commissioners were appointed to lead an inquiry into the state of education in Wales and to report on "the condition and character of the people". The commissioners-middle-class English Anglicans who knew nothing of Wales, its history, language or culture-concluded not only that most Welsh schools were inadequate, but that most Welsh people were liars, cheats, thieves and sexually promiscuous-and, further, that these characteristics were related to the fact that most of them were Welshspeaking Nonconformists. The commissioners' report appeared in 1847 and sparked outrage in Wales; one of the most effective responses to it was Artegall (1848), a pamphlet by Jane Williams (Ysgafell). This article examines the ways in which Williams drew on material from sociology, history, literature and linguistics to argue against the commissioners' political motives, and deployed mockery to undermine their pretensions to authoritative judgement. It also analyses a contemporary response to Artegall: an 1848 cartoon by Hugh Hughes which demonstrates both his admiration for Williams' writing and his complete inability to depict her.
\end{abstract}

There have been many commissions of inquiry whose findings were relevant to Wales, and there have been several commissions of inquiry which focused specifically on Welsh matters; most of the reports they produced are now familiar only to historians of the period or to others with a professional interest in their subjects. Only one commission of inquiry focusing specifically on Welsh matters has entered into Welsh national mythology sufficiently for its report to have acquired a generally recognized nickname: the Report into the State of Education in Wales, which was published in three parts between 1846 and 1847, became known in Wales as "Brad y Llyfrau Gleision" ("The Treachery of the Blue Books"). ${ }^{2}$ How Wales and the Welsh were regarded by the English had always been an important component of Welsh national identity, 
especially after Wales had been officially incorporated into England for political and administrative purposes by Henry VIII's Acts of Union (1536 and 1543). To Wales in the middle of the nineteenth century-"a small bereft nation frantic with longing for a commendable place in the English imperial sun", in the words of one distinguished historian-the Report came as a psychological bombshell; it made clear to the Welsh people that what the English thought of them was even worse than they had feared. ${ }^{3}$

The Report presented the Welsh (with a few shining exceptions) as liars, cheats and thieves who neglected their personal hygiene and were sexually promiscuous-and, further, it implied that these characteristics were related to the fact that most of them were religious Nonconformists and spoke Welsh as their first language. Not surprisingly, the reaction in Wales was immediate, outraged and bitter. The Report's publication produced a large number of books and articles (the majority of them by male commentators) which argued fiercely against the Report's approach, methods of inquiry and conclusions. The most hard-hitting and effective was the 1848 pamphlet Artegall by Jane Williams (Ysgafell, 1806-85). This article will consider its context, its author and her methods, and one of the most important responses to it, to argue that it remains one of the most interesting and significant pieces of political writing by a woman in Wales in the nineteenth century, and contemporary reactions to it among the most revealing. ${ }^{4}$

The Report was prompted by the high level of civil unrest in Wales during the previous half-century. Some incidents arose from local and particular grievances: strikes, demonstrations against wage cuts, and the activities of secret organizations such as the Scotch Cattle (in newly industrialized south Wales) and the Daughters of Rebecca (in rural areas), which were aimed at unjust employment practices and excessive road tolls. Others had explicitly political roots: in the Merthyr Rising of 1831, the centre of the town was held for four days against the army and the militia in a rebellion which started as a protest against reductions in wages and became a campaign for political unions and parliamentary reform, while the Newport Rising of 1839 was in support of Chartist demands for universal male suffrage and electoral and parliamentary reform. Tensions continued throughout the 1840s. Local magistrates' inability to build up a network of informers was attributed by some commentators to the language barrier: the London Morning Chronicle commented afterwards that it was far easier to foment civil unrest "in a district where the lower orders speak almost universally a language unknown to the educated classes" ". The remedy for this dangerous disaffection was clearly to teach the Welsh working class views and values which would be more acceptable to those who governed them, and an inquiry into the current state of education in Wales was necessary before appropriate measures could be devised. The Member of Parliament who made the formal request for the inquiry (William Williams, who had "risen" from a poor Welsh-speaking 
background to make a fortune in the cotton trade, and who attributed much of his success to his knowledge of English) declared that, "if the [Welsh] people had been acquainted with the English language [and] had proper instruction been provided, instead of being as they now are, a prey to designing hypocrites with religion on their lips and wickedness in their hearts", the disaffection expressed in civil unrest might never have developed. ${ }^{6}$ The political aims of the inquiry were very clear.

Three commissioners-all male, middle-class English Anglican lawyers who knew nothing of Wales, its history, language or culture, and whose lack of knowledge was regarded as proof of their objectivity ${ }^{7}$-were accordingly appointed to lead an inquiry into the state of education in Wales and to report on "the character and condition of the population"; the publication of their Report became a defining moment in Welsh history. ${ }^{8}$ One historian regards it as playing a part in the Welsh historical imagination analogous to that of the notorious Cromwellian massacre for later generations in Ireland, describing it as "passed down in folk memory as a kind of Welsh Drogheda"; another has seen it as the source of both positive and negative attitudes towards what it means to be Welsh. ${ }^{9}$ While many contemporary Welsh writers criticized the often sensationalist language in which the commissioners reported their findings and also challenged their statistics, they tacitly accepted the self-conscious authority with which the commissioners pronounced their judgements. Jane Williams, by contrast, in addition to criticizing unmercifully the commissioners' statistics and use of language, clearly understood that the most effective way to undermine the Report's conclusions was to undermine the authority with which the commissioners pronounced those conclusions, and that the most powerful tools with which to do this were the mockery and contempt which could describe its conclusions as not only "illogical and unfair", but also "nonsense".

Public education in mid nineteenth-century Wales was less a system than a tangled coil in which education, religion and language were tightly intermeshed. There were national schools, which were closely tied to the Church of England and received the largest share of government grants. There were (non-Anglican) British schools, which received less funding; as a result, there were fewer of them, and some Nonconformist parents had either to send their children to national schools or deprive them of formal education. There were schools set up by Roman Catholics, Jews and Nonconformist denominations, which depended on private initiatives and were randomly distributed across the country. There were a few endowed schools, which were usually constrained by centuries-old trust deeds and sometimes run as the private fiefdoms of local landowners or clergy. And there were private "adventure" schools, often held in outhouses, stables or back kitchens by near paupers in order to scratch a living (and favoured by parish authorities because this employment removed the teachers from the Poor Relief rolls). 
Some schools operated for only three months of the year; others were closed in spring and summer so that the children could work in the fields. Most of these day schools required payment from parents; for some children, especially after the age when they could work, the only source of education was the Sunday school. Many Welsh parents regarded learning English as the most important component of their children's education, since it opened up opportunities for jobs and social advancement; but some teachers (especially in "adventure" schools) had only a slight and imperfect knowledge of the language themselves. In spite of this, there were often severe punishments for children caught speaking Welsh in day schools (and sometimes outside them also); many Sunday schools, however, operated through the medium of Welsh and taught reading so that children could read the Bible.

To some political commentators, members of the working class who had learned to read (for whatever purpose) represented a potential threat, since their skills gave them access to subversive reading matter-with the results seen in recent civil unrest as well as in criminal behaviour in general. But Sir James Shuttleworth (later Kay-Shuttleworth), the secretary of the Committee of Council on Education and the man responsible for setting up the inquiry on education in Wales, regarded education for the working class as a means of turning "pauper children [who were] addicted to lying, swearing and petty thieving", and who demonstrated "a lack of energy in work, and cunning in evasion of labour", into children who were "more docile, orderly and intelligent". ${ }^{10}$ Many people in Wales were aware that while some Welsh schools had excellent teachers, buildings and equipment, many did not, and that public educational provision as a whole was inadequate. For these reasons, they had welcomed the inquiry as the first step in educational reorganization and reform; consequently, much of the outcry at the Report (and its nickname) arose from their sense that their trust in the good intentions of the government had been betrayed. Suspicion of the government's motives pervades Artegall; like many other commentators, Williams saw the Report's picture of education in Wales as the government's pretext for taking control of Welsh schools to further its own political and social agenda.

\section{The liminality of Jane Williams}

Williams' family background and early life placed her in a very different position in relation to Wales and England from that of other commentators, and Artegall gains much of its success as a polemic from the way in which she took advantage of this position. Her father was Welsh, her mother English; she grew up in comfortable affluence in London and southern England, giving her the opportunity to develop interests in Roman, European and British history, and in English literature. When she was in her mid teens, her 
family lost most of its money and moved to Wales; the financial disaster meant that she needed to be self-supporting, and she found work in rural Breconshire, first as the equivalent of an au pair for a family with seven children and later as a lady's companion to a rich landowner. She self-published a collection of poems in 1824 when she was 18 and produced two religious tracts in the late 1830s. By the early 1840s she was in her mid thirties, and there must have seemed little reason to expect that the future would offer her more than a lifetime of similar employment, finding sympathetic employers if she was lucky but having to bear demeaning treatment if she was not. By 1845, however, her life and prospects had been transformed by two remarkable strokes of luck. Firstly, her second employer left her $£ 100$ a year for lifeenough for a single middle-class woman to live on independently if she avoided extravagance. ${ }^{11}$ Secondly, during the same period, she met Augusta Hall (1802-96, later Lady Hall and, later still, Lady Llanover), and her social and literary lives were transformed as a result.

When Williams first met her, Hall was already a major figure in social, cultural and political circles in south Wales and London. Her husband was a Member of Parliament and they spent part of each year at their London house, where Hall used their social and political connections with the metropolitan elite to raise the profile of Wales and Welsh culture, especially its music. She was a major patron of eisteddfodau, supported the Welsh Manuscript Society, and played a major role in codifying "traditional" Welsh women's costume (she wore her own version of Welsh dress in south Wales and on special occasions in London). After inheriting the Llanover estate in Monmouthshire, she had had a new house built on Elizabethan lines (including a minstrels' gallery) to accommodate large house parties for the cultural, social and intellectual elite of both Wales and London. ${ }^{12}$

The freedom of movement which Williams gained through her second employer's legacy allowed her both to accompany Hall on visits to London and to become a frequent visitor at Llanover Court, where its impressive library became a vital resource for her in a period before the establishment of the public library lending system and when access to other major libraries was difficult or impossible for a woman. Through Hall's friendship and patronage, Williams also became part of social and literary circles in both Wales and London, from whose members she could learn about subjects which interested her-particularly important since her formal education had ended when she was in her mid teens. The publication of Artegall demonstrates very clearly the advantages to her of Hall's patronage: Hall not only paid the pamphlet's publication costs, but also engaged in skilful publicrelations work on its behalf.

The pamphlet was specifically directed to influential people in London - "Ministers of State, noblemen, M.P.s [Members of Parliament], reviewers and editors of newspapers", in Hall's words to its printer-to convince 
them of the inaccuracies and unfairness of the Report's conclusions. Hall arranged for copies in an expensive and high-quality edition, which she felt would be more likely to attract attention, to be sent individually to these opinion-formers (after much urging from the publisher, she reluctantly agreed that a cheaper edition in smaller type on inferior paper could be produced for "the lower orders"). Artegall was to be published anonymously, and a personal letter from Hall recommending the book to each recipient was enclosed with each copy; she was aware that this would give rise to rumours that she was the author, and that a book thought to be by the celebrated Lady Hall would create far more of a stir than the same book written by an author known only to her friends and family. ${ }^{13}$

Every aspect of Williams' life during the period when she wrote Artegall (and, indeed, the rest of her life) demonstrates liminality in the definition proposed by Rob Shields: "Classic liminality occurs when people are in transition from one station of life to another or from one culturally-defined space to another". ${ }^{14}$ Williams had crossed national and geographical boundaries by moving from England to Wales and from urban to rural areas, and social and financial boundaries first by moving from being a member of an affluent middle-class family to an employee in the homes of others, and then by becoming again an independent member of the middle class. Her linguistic, cultural and educational grounding had been in the English language, English literature and English history; after moving to Wales, she learned Welsh and read widely in Welsh literature and history, moving from an upbringing among English cultural norms to a knowledge and appreciation of Welsh culture. And although important aspects of the formation of her personal identity-linguistic, literary and cultural—had been solidly English, she was also aware of her strong social, local and ancestral connections to Wales through her father-who, to add another level of complexity, had himself come from a liminal area: the borderlands between Wales and England (his home village, Evenjobb in Radnorshire, is a short walk from Offa's Dyke).

One of the most interesting aspects of Artegall is the way in which Williams used this liminality as an advantage, presenting herself as equally knowledgeable about the language, literature, history and culture of both Wales and England, and therefore able to act as an impartial observer who could explain the people of one country to those of the other. Artegall also uses the fact that the cultural formation of its intended readership of English metropolitan opinion-formers would mean they were familiar with the English literary canon (or at least would make respectful obeisance to the great names of English literature). The pamphlet's title refers to one of the less prominent characters in one of the less prominent books of Spenser's Faerie Queene, and its text makes other references to Spenser, as well as to Dryden, Pope, Johnson, Gray and the eighteenth-century grammarian Lindley Murray, so that the readers at whom the book was directed were 
made fully aware that the author shared their educational, literary and cultural background. The effect was to make clear that the book was not a parochial and biased expression of resentment by a local writer unable to appreciate the context and importance of a government report, but the work of a wellread and sophisticated author; its readers were being invited to read the pamphlet from the same perspective, and then to judge it on its merits, and not dismiss it out of hand as flawed by personal resentment and regional prejudice.

\section{Artegall: the argument}

From the epigraph on the title page of Artegall to its final sentence, Williams wished her readers to appreciate that her analysis of the Report was made from a far wider perspective than Welsh education alone, and she articulated her response to it in specifically moral terms. The epigraph, from The Faerie Queene, both explains the pamphlet's title and establishes its moral context: "Then take the right likewise, said Artegall, / And counterpoise the same with so much wrong". ${ }^{15}$ The pamphlet's first paragraph then moves to a particular example of "so much wrong", the commissioners' Report:

The Reports of the Commissioners of Inquiry into the State of Education in Wales have done the people of that country a double wrong. They have traduced their national character and in so doing they have threatened an infringement upon their manifest social rights, their dearest existing interests, comprised in their ordinary modes of worship and instruction, their local customs, and their mother tongue. (5)

Since no reader is likely to opt for "the wrong" over "the right" (however those terms are defined), Williams has made any support for the commissioners and their conclusions virtually impossible from the outset (especially when these general moral terms are reinforced by emotive vocabulary such as "traduced" and "threatened [...] infringement [of] rights"). The second sentence deepens her accusation by declaring that the commissioners had done the Welsh people not merely one wrong, but two: slandering them as a nation and attempting to curtail their civil liberties.

In her next paragraph, Williams asserts that the British people have been misled into accepting the commissioners' personal prejudices as an objective account-" The British public appear generally to have received the Commissioners' personal Reports as a judicial summing up of the Evidence they have adduced" - and argues that the Report was not only biased, but deliberately so: "Those reports are, on the contrary, the practical interferences of advocates, the special pleadings of Counsels for the prosecution in the cause Shuttleworth versus Wales" (5). Shuttleworth saw the fact that the commissioners were barristers as proof that they would be able to elicit "the facts" from 
witnesses; Williams turns this assumption on its head by reminding her readers that barristers are paid to represent one side against the other, and asserting that the commissioners were working for the prosecution. She offers a reason for this in the pamphlet's final paragraph. Shuttleworth, she declares, was attempting to make Wales "the victim of an educational experiment": "the direct and unprecedented interference of the Executive Government in the regular management and inspection of schools" (62). Her attack on the Report, therefore, rests on the argument that not merely was its evidence biased and its conclusions inaccurate, but that the government's ulterior motives had always been to take over public education in Wales in order to further its own political agenda. In her view, the only means to hinder this plan was (in the final words of the pamphlet) "Preventive Opposition from the watchful Friends of British Liberty" (62). Williams' accusation that the government's plans would infringe not merely the "manifest social rights" (5) of the Welsh people but "British Liberty" itself was designed to send her readers a clear warning: if the government succeeded in Wales, it would "interfere" in public education throughout Britain.

Accordingly, Williams needed to rebut and undermine the commissioners' conclusions in detail and from every possible standpoint-and she did. She attacked both their use of statistics (which, she said, they misinterpreted in order to support their prejudices) and the quality of the evidence they elicited and how they treated it, accusing them of giving more credence to informants "whose ill will, inexperience or prejudice rendered them incompetent than to those of real weight and knowledge" (7), and alleging that "[t]he majority of the witnesses had a direct personal interest in furthering the plans of the Commissioners" (15). She further accused them of presenting "conclusions" which contradicted the evidence they themselves had collected. She declared that the commissioners' presumptuous conclusions about "the character of the Welsh people" demonstrated only their total ignorance, that their generalizations were inaccurate on every subject from Sabbath observance to the domestication of poultry, and that when one of the commissioners pontificated about girls' domestic work in rural areas, "any Welsh matron would readily inform him" that he was completely wrong. "These gentlemen cannot realise the necessities of rustic life", she wrote witheringly (32-33); by implication, she did.

At the same time, she used her knowledge of England and English literature and history to speak to her English metropolitan readership as their equal, who shared their cultural formation, knowledge and perspective. In response to the Report's accusation that the Welsh believed in "charms, supernatural appearances and even in witchcraft [when] civilisation and light ha[d] long ago banished these remnants of the dark ages elsewhere", she inquired sarcastically, "Does elsewhere mean England? Does it include London?" (original emphasis), and then quoted an article in the Athenaeum on the number of 
books on astrology and magic on sale in England, which observed: "There are shops in London which deal in nothing but this pernicious diet" (29-30). When one of the commissioners criticized Welsh children for not answering him immediately in fluent English when he made unannounced visits to schools and subjected the pupils to "exhaustive examinations", she observed caustically that similarly unscheduled visits to "English boarding schools to carry out examination on all the various topics of instruction $[\ldots]$ in French" would produce equally uncertain and ungrammatical replies, and she compared the attempt to impose English on the Welsh people with Norman attempts to impose their language on "the depressed and despised Saxon" after the Norman Conquest, adding triumphantly: "They [the Normans] tried various means to effect it and they failed" (57). Just as she had used the fact that her readers would automatically side with "the right" against "the wrong" at the beginning of the pamphlet, so at this point she used contemporary pride in the Saxon origins of the English people to persuade her readers by analogy that the Welsh people had the same right to speak the Welsh language as the English did to speak their Saxon-based language-which, she pointed out, contained many words derived from Latin and Celtic roots, as well as Norman French. The English were in no position to claim linguistic purity.

If Artegall had only drawn attention to the factual inaccuracies and prejudices observable in the Report, it would have been merely one protest among many. Williams' pamphlet, however, demonstrates two additional characteristics which give it a strongly individual flavour. The first is the vigour of her condemnation; she wrote that the evidence of one witness was "disgusting" and that statements given in evidence by others were "so incompetent [that] they ought never to have obtained a place [even] in the Index" (10). Her judgement on a passage by one commissioner, which began "The Welsh language is a vast drawback to Wales" and ended "There is no Welsh literature worthy of the name", was a dismissive "This is such manifest tirade as scarcely to deserve a comment"-so she refused to dignify it with one (53). After quoting a long, vague and structurally confused sentence by another commissioner, she expressed the sardonic hope that when Shuttleworth read it he "had a key to the cypher [sic]; to the uninitiated it reads very much like nonsense" (56, original emphasis), while another passage received the damning verdict: "one of the most feeble in structure and indistinct in expression that ever reflected the form of a vague and cloudy thought" (41).

Secondly, she targeted not only the accuracy and fairness of the commissioners' judgements, but also the way they expressed them: Artegall includes a section specifically directed at the language of the Report. The commissioners' command of English was "pitiable", she declared (43), pointing out that while they recorded "the slightest inaccuracy in the English phraseology 
of the schoolteacher and mark[ed] it with contempt" (40), their own English was notable for its egregious mistakes; the Report's grammar was so faulty that "a set of exercises on grammatical errors might indeed be compiled from the writings of the Commissioners for the cautionary use of Welshmen studying the English language" (41). She demonstrated this by quoting grammatical rules established by recognized linguistic authorities and then listing ways in which the commissioners flouted them: for example, lack of agreement between noun and verb, the application to a place of an adjective properly only used of people, and a verb which required a human subject used with an abstract noun. Many of the examples she subjected to particularly withering analysis were taken from the second part of the Report, and her conclusions on this commissioner's use of English are reminiscent of the response of a weary schoolteacher to the predictably weak, but still depressing, work of a particularly unintelligent and recalcitrant pupil: until the commissioner "attains a more creditable knowledge of etymology and syntax, we would earnestly recommend him to abstain from the use of metaphors and from all figures of speech" (43).

As these examples demonstrate, one of her major instruments of attack was mockery; she mocked the commissioners' complacency in the rightness of their own conclusions, their illogicality, and their habit of condemning the Welsh people for things they had not done but which the commissioners thought they might possibly have done in circumstances which did not actually exist. She also turned their own words against them-for example, mocking the ridiculous lengths to which their preconceived opinions on Welsh schools had led them: "Everything is wrong in their eyes; even the Infant Schools are 'too exclusively infantine" (36). Her immediate pointthat to criticize an infants' school for being a school for infants is not merely "illogical and unfair", but ludicrously so-gains its effect from the way she uses a direct quotation from the Report itself to illustrate her charge that the commissioners were not only prejudiced, but also intellectually inadequate for their task.

These magisterially sweeping criticisms show more than a willingness to challenge the authority of an official report; they also communicate a sense of Williams' enjoyment of her task of destructive criticism. Artegall's verdict on the Report was doubly damning: not only had it perpetrated a moral wrong, but it had done so in ungrammatical English. Contempt and mockery were the only possible responses.

\section{"Artegall": the cartoon}

One of the most revealing responses to Artegall in Wales was a cartoon by Hugh Hughes in the series Pictures for the Millions of Wales, also published in $1848 .{ }^{16}$ His cartoons lambasted the commissioners, their prejudiced 
witnesses (especially the Anglican clergy) and those who had sent them to Wales; Shuttleworth becomes Scuttleworth, with a coal scuttle on his head, bribing the commissioners to come to the conclusions he wants (No. 2), while Lord John Russell, the prime minister who commissioned the Report, is drawn as a fey midget whose aim is "covertly and by degrees" to impose Anglicanism on Nonconformist Wales (No. 1; original emphasis). Only two of the cartoons show Welsh writers responding to the Report. The first is the Reverend Evan Jones (Ieuan Gwynedd), the author of influential attacks on the Report in both English and Welsh, who is shown admiringly as a handsome, energetic animal-tamer who has caught the ferocious black wolf of the Report, put it in a cage, and is boldly poking it through the bars with a pen-like lance (No. 4); the second is Jane Williams (No. 9).

By the time the cartoons were published, the author of Artegall had been identified as a Miss Jane Williams, although apparently nothing was known of her but her name. Hughes's cartoon, "Artegall; or, The Whipping/Y Fflangelliad" (Figure 1), took its cue from the fact that the tone of Williams' pamphlet often, as mentioned earlier, suggested the response of a wearily, irritable teacher to intellectually challenged pupils. The cartoon shows the three commissioners (wearing wigs to show that they are barristers) as naughty schoolboys bawling in frightened anticipation of the whipping they are about to receive from the large and fearsome birch held by their teacher. The cartoon is accompanied by two texts, one in Welsh and one in English; the Welsh text is slightly longer, partly because it was explicitly intended

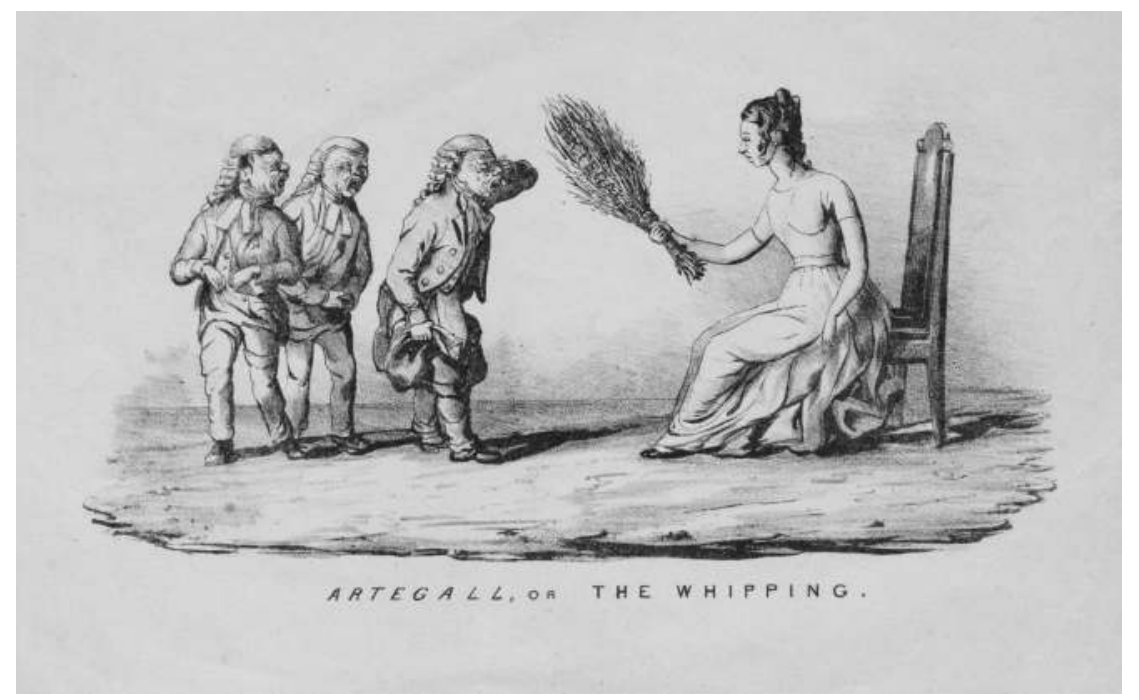

Figure 1 Hugh Hughes, 'Artegall, or the Whipping', 1848 in Pictures for the millions in Wales. By permission of the National Library of Wales. 
for monoglot Welsh readers who needed the significance of Artegall and the Report explained to them, whereas the English text assumed that its readers were familiar with the contents of the Report and had at least heard of Artegall.

Both texts are written as monologues for Miss Jane Williams as she prepares to whip the commissioners (who occasionally interject, "Oh, please no, Miss, we'll never do it again"), but the tone of the Welsh is notably harsher than the English. Whereas the English text keeps the literary reference of Artegall's title, the Welsh title ("Y Fflangelliad": "The Whipping" or "The Scourging") emphasizes the physical violence which the commissioner-schoolboys are to suffer; whereas the English text has Miss Jane Williams saying, "I am sorry to have to lay the rod to your bare backs, but you are such naughty boys that I must", the Welsh version has her threatening to flog them so hard and for so long that the birch in her hand will be worn to a mere stump; and whereas the English text merely accuses the commissioners of "slandering and lying", the Welsh text insults them as filthy wretches with neither sense in their heads nor goodness in their hearts. ${ }^{17}$ Interestingly, there is a far greater difference in content and tone between the captions in the two languages to this cartoon than those to any of the others and, in contrast to the depiction of the commissioners in other cartoons, where they are merely represented as shifty-looking human beings, in this one their faces are noticeably more repulsive, and almost reptilian.

Both the Welsh and English captions to this cartoon demonstrate warm approval for Artegall and its author; the Welsh version refers to her as "boneddiges wlatgarol" ("a patriotic lady") for her defence of the Welsh people. This approval makes the way in which the cartoonist chose to depict her particularly revealing (especially when set beside the heroic handsomeness of Evan Jones). Cartoonists during this period tended to use a fairly limited repertoire of stereotypes when representing women: the innocent young girl, the virago, the contented wife and mother, the grand lady, the old crone, and so on. Among them was the schoolmistress, typically shown as sharing many visual characteristics with the stereotype of the "old maid": thin, flatchested, sour-faced and graceless. A schoolmistress was typically shown as a figure of fun, certainly not someone to be taken seriously.

This presented Hugh Hughes with a problem, since the author of a detailed and methodical dissection of an official government report, whose analysis was both intellectually impressive and patriotic, could not be dismissed as a figure of fun. The cartoon Miss Jane Williams bears some traces of the stereotypical features of a schoolmistress (the thin face and receding chin), but has the hairstyle, dress and body of a very different stereotype: the sort of young woman who would typically be told not to worry her pretty little head about government reports-and who also would not be taken seriously. Giving her a face to match her body would have failed to communicate her schoolmistress 
role at a glance (also, showing a nubile young woman about to birch three bare male backsides might have been regarded as unsuitable for family viewing); the lack of clarity in the image chosen to represent the author of Artegall results in an uneasy hybrid. A woman who wrote a detailed and effective critique of an official report did not fit any of the cartoonist's stereotypes and could not be described in the terms available to him; Hughes admired her pamphlet and fully supported its views and conclusions, but at another level he did not know what to do with her. The wider significance of the cartoon lies in the way it reveals some of the obstacles faced by a female author of the period who wrote on "serious" subjects, even from those who agreed with her arguments. Hughes's cartoon suggests that while he admired what she wrote, he found it difficult to deal with the fact that a woman had written it. The percentage of books published in Britain in the nineteenth century by women writing under their own names was $14 \%$; for those writing on "serious" subjects, the figure was approximately $0.6 \%$. Williams was in a minority of a minority. ${ }^{18}$

Nine years earlier, Williams, a devout Anglican, in a riposte to a tract written by a member of the Plymouth Brethren, had used the same techniques as in Artegall: to demolish a text's arguments on the grounds of inaccuracy, illogicality and sloppy English. ${ }^{19}$ Her tract is both shorter and slighter than Artegall, but can be seen as an (unconscious) practice piece, demonstrating the same enjoyment in identifying and mocking the weaknesses of a piece of English prose whose arguments offended her. Certainly, in writing Artegall, she had the support of Hall and the other members of her circle, but as the work of a woman writing for publication in the 1840s who was previously unknown to the reading public, its assurance, authority and vigour are remarkable. The cause of this confidence is to be found in the fact that she was not merely expressing her own damning opinion of the Report, but was doing so on behalf of the Welsh people; it is this which allows her to position her criticism of the Report within moral terms. She was using her talent as a writer in the service of a cause greater than herself-to defend those who could not defend themselves in terms their accusers would recognize-and, at the same time, enjoying herself enormously.

In the service of this cause, she deployed not only her wide reading, but also the fact that many aspects of her personal identity-her family history, her early life, her linguistic and literary background-were neither wholly Welsh nor wholly English. Locating herself in the metaphorical borderlands between the two countries and cultures meant that she could use this liminality to speak from a position within Welsh society and culture while using the same language-literally and metaphorically-as her English metropolitan readership, and present herself to them not as a partisan biased in favour of the Welsh, but as an authoritative anthropologist whose conclusions could be trusted. 
The self-publication of her collection of adolescent poems can be seen as her determined assertion that she was a writer, not a childminder; her two religious tracts can be seen as (unconscious) prose practice pieces. In Artegall, with its very individual combination of detailed textual analysis and sardonic mockery, she found her voice and literary personality. Her career as a professional writer extended for more than 50 years and across a wide range of genres-poetry, history, biography, short stories, literary criticism, the social and political aspects of contemporary religious debates, and a memoir of childhood-and, after Artegall, all her books, with one ill-advised and unsuccessful exception, related to Wales. The pamphlet drew the attention of the Welsh public to her (in more respectful terms than the cheerful knockabout of Hughes's cartoon) and established her as a writer to watch; years later, her books still identified her on the title page as "Author of Artegall". More than 160 years later, Artegall is still an entertaining and invigorating read, and remains one of the most interesting and important pieces of political writing by a woman in Wales in the nineteenth century-and the contemporary response to it by one of its admirers one of the most revealing.

\section{Notes}

1. Jane Williams, Artegall: or, Remarks on the Reports of the Commissioners of Inquiry into the State of Education in Wales (London: Longman, 1848), p. 24; 1st cheap ed. "for the lower orders". Subsequent references are cited parenthetically and are to this edition. "Ysgafell" was her chosen bardic/writing name-the name of an ancestral estate near Newtown in mid Wales which her father would have inherited if his father had not sold it (and spent the proceeds). "Ieuan Gwynedd" was the bardic name of the Reverend Evan Jones, mentioned later in relation to Hugh Hughes's cartoon. An advantage of bardic names is that they enable their users to be distinguished from other people with identical forenames and surnames.

2. For a detailed discussion of the Report and its context, see Gwyneth Tyson Roberts, The Language of the Blue Books: Wales and Colonial Prejudice (Cardiff: U of Wales P, 1998).

3. Hywel Teifi Edwards, The Eisteddfod (Cardiff: U of Wales P, 1990), p. 21.

4. See Jane Aaron and Ursula Masson, eds., The Very Salt of Life: Welsh Women's Political Writings from Chartism to Suffrage (Dinas Powys: Honno, 2007), esp. 5-9, 18-50; Jane Aaron, Nineteenth-Century Women's Writing in Wales (Cardiff: U of Wales P, 2010), esp. 74-78.

5. Qtd. in Ivor Wilks, South Wales and the Rising of 1839 (London: Croom, 1976), p. 26.

6. Hansard (London: HMSO, 1846), XXIV, 846.

7. For example, James Mill (father of John Stuart) said that the fact that he had never been to India and was completely ignorant of any Indian language could only be an advantage in writing "an impartial and true history of the country", since it allowed him to be an objective judge of its events. See Hans Aarsleff, The Study of Language in England 1780-1860 (London: Athlone, 1983), p. 140. 
8. Reports of the Commissioners of Inquiry into the State of Education in Wales (London: HMSO, 1847), pt. 1, p. 4.

9. Kenneth O. Morgan, Wales 1880-1980: Rebirth of a Nation (Oxford: Oxford UP and U of Wales P, 1982), p. 23; Prys Morgan, Brad y Llyfrau Gleision (Llandysul: Gwasg Gomer, 1991), pp. 223-25.

10. Sir James Kay-Shuttleworth, The Autobiography of Sir James Kay-Shuttleworth, ed. B. C. Bloomfield, Education Libraries Bulletin, supp. 7 (1877; London: Inst. of Education, U of London, 1964), pp. 27, 29. For Shuttleworth's fuller expression of his views, see Sir James Kay-Shuttleworth, The School in Its Relation to the State, the Church and the Congregation (London: John Murray, 1847) and, for their biographical context, R. J. W. Selleck, James Kay-Shuttleworth: Journey of an Outsider (Ilford: Woburn, 1994), esp. ch. 6.

11. See the will of Isabella Hughes of Glasbury, Prerogative Court of Canterbury Wills, PROB 11/2021.

12. See Rachel Ley, Arglwyddes Llanofer: Gwenynen Gwent (Caernarfon: Gwasg Gwynedd, 2001); Michael Freeman, "Lady Llanover and the Welsh Costume Prints", National Library of Wales Journal, 34.2 (2007): 235-51; Celyn Gurden-Williams, "Lady Llanover and the Creation of a Welsh Utopia", PhD thesis, Cardiff U, 2008.

13. See Tonn ms. 3.109A, Cardiff Central Lib., Cardiff. These letters about Artegall, from Hall to the Welsh printer of the pamphlet (William Rees of Llandovery), have not been individually catalogued.

14. Rob Shields, Places on the Margin: Alternative Geographies of Modernity (London: Routledge, 1991), p. 83.

15. Edmund Spenser, The Faerie Queene, ed. A. C. Hamilton, text edited by Hiroshi Yamashita and Toshiyuki Suzuki (Harlow, Essex: Pearson Educational Ltd, 2001) p. 523.

16. For a full account of the series of cartoons, see Prys Morgan, "Pictures for the Millions of Wales, 1848: The Political Cartoons of Hugh Hughes", Transactions of the Honourable Society of the Cymmrodorion, 1 (1995): 65-80. Hugh Hughes (1790-1863) was an artist and publisher with radical tendencies.

17. "Mi a'ch chwipiaf nes bydd y wialen yma yn bwt yn fy llaw i"; "Nid oes dim synwyr yn eich pennau na daioni yn eich calonnau, y burguniaid bryntion".

18. Nigel Cross, The Common Writer: Life in Nineteenth-Century Grub Street (Cambridge: Cambridge UP, 1985), pp. 167-68.

19. Brief Remarks on a Tract entitled "A Call to the Converted" (Hereford: T. T. Davies, 1839).

\section{Disclosure statement}

No potential conflict of interest was reported by the author. 


\title{
ADAPTING THE RISORGIMENTO: IDEAS OF LIBERAL NATIONHOOD IN L. M. SPOONER'S COUNTRY LANDLORDS (1860)
}

\author{
Rita Singer (D)
}

\begin{abstract}
For the Welsh middle classes, the 1850s were defined by a continuous struggle against English stereotypes that imagined Wales as a nation of promiscuous drunkards, incapable of self-rule and a burden for Britain. Whereas the Welsh press aggressively rebuffed such frequent accusations as soon as they sprung up, it took another 10 years before anglophone literature in Wales began to challenge Anglocentric perceptions of the Welsh nation. Louisa Matilda Spooner was one of the first novelists who rejected the continued marginalization of Wales owing to its geographical distance from London, Britain's centre of art, commerce and politics. In her second work, Country Landlords (1860), she explores how liberalism, philanthropy and Giuseppe Mazzini's republicanism form ideal prerequisites for Welsh squires. Under these circumstances, Welshness turns into a facet of Britishness because the ideal landlord in Wales fiercely defends his Welsh heritage and manages his property independently while remaining loyal to the union state.
\end{abstract}

In 1860, Louisa Matilda Spooner published Country Landlords, the second of her extant three novels. ${ }^{1}$ As one of the early contributions to a tradition of the Welsh novel in English, this Whiggish romance explores responsibilities of the Welsh nobility and gentry in the construction of a healthy national community at a time when, in the wider British context, Wales was regarded as little more than an administrative region of England. Chiefly, the story follows the prolonged rivalry between two neighbouring estates near the coast of west Wales. The two young lovers, Anarawd Gwynne and the English-born Gertrude Fitzhammons, suffer under the antagonism between their (foster-)fathers, who represent opposite poles of the Welsh squirearchy. On the one side, there is the spendthrift Owen Herbert Gwynne, who stems from a long line of Welsh noblemen; and on the other side, there is the retired sea captain Ricardo Lewis of part-Italian descent, who has only recently settled nearby. Eventually, Captain Lewis is forced to flee Britain because Gertrude's remaining family discover that he had effectively 
kidnapped the girl after her parents' death and raised her like a daughter. Shortly after he and Gertrude reunite in Naples, Lewis is betrayed by an old enemy and he is killed whilst fighting on the barricades for a united Italian republic in 1848. After their fathers' deaths, Gertrude and Anarawd return to Wales for good and unite their inherited estates for the benefit of the entire nearby village as they marry and found their own Anglo-Welsh family.

Not much is known about the personal background of Louisa Matilda Spooner (1820-86), except that she was the fifth of 10 children of Elizabeth and James Spooner from Birmingham, and spent most of her life in the Porthmadog area in Merionethshire, eventually living as a spinster together with her brother and his family. ${ }^{2}$ Her English and comfortably middle-class family background provides Spooner with a double vision of the largely Welsh-speaking and Nonconformist community life in north-west Wales, and influences the content and ideology of Country Landlords accordingly. Based on the descriptions of geographical landscape features, concrete place names, and references to economy and infrastructure, the novel is set in Spooner's native, if slightly fictionalized Merionethshire of her youth and early maturity. Subsequently, Country Landlords reflects the favourable economic and political, as well as language changes affecting the Welsh middle classes up to the 1860s, while the vast majority of the Welsh peasant and working classes were subjected to "appalling living and working conditions". ${ }^{3}$ The social upward mobility of the comparatively small middle class in Wales expressed itself in a heightened civic confidence, as is evident, for example, in the heated public debate surrounding the Reports of the Commissioners of Inquiry into the State of Education in Wales (hereafter shortened to Reports) in 1847 in many weekly newspapers and periodicals published across Wales. ${ }^{4}$ The "Treachery of the Blue Books", as the Reports were soon renamed by their critics in Wales, dominated the columns of such weekly newspapers as the Principality: An Advocate of Civil, Commercial, and Religious Freedom (1847-50) from Haverfordwest (and later Cardiff) on the radical end of the political spectrum, as well as the more moderate Swansea and Glamorgan Herald and South Wales Free Press (1847-90). ${ }^{5}$ Despite the relative distance between the release of the Reports and Spooner's novels over a decade later, her literary construction of Welsh communities suggests the formation of a counterdiscourse that particularly rejects the accusations issued against Welsh women for their supposed lewdness. ${ }^{6}$

In this heated climate of public debate in the periodical and news press, portrayals of Welsh-language culture increasingly found their way into other anglophone domains such as the novel, to whose popularity Spooner contributed in Wales, as is evident by the Cambrian Journal's favourable review of her first novel, Gladys of Harlech; or, The Sacrifice (1858): 
Until the last few years we had no books of fiction, illustrative of Welsh manners and customs, that a genuine Cymro could for a moment tolerate [ ... ]. [T] he true spirit of patriotism [ ... ] penetrates [... Gladys of Harlech, and gives life and vigour $[\ldots]$, which is refreshing to contemplate. ${ }^{7}$

In contrast to the enthusiastic reception of Gladys of Harlech in Wales, Geraldine Endsor Jewsbury, a reviewer for the Athenoum, dismissed Spooner's second work as "a quasi Welsh story; but it suggests a suspicion that the writer is not a genuine Welsh woman, nor yet well up in points of national manners and customs. The characters do not smack of the Principality". Most likely it is Spooner's choice to set the story among the Welsh gentry that triggers this critique, as it inevitably tips the scale towards the portrayal of the most anglicized section of Welsh society. ${ }^{9}$

Even though Endsor Jewsbury finds explicit examples of life in the Welsh hinterland missing, the social field constructed in Country Landlords in fact clearly follows in the footsteps of the idealized and contemporary imagination of the gwerin-i.e. the comparatively egalitarian ordinary folk of Wales. ${ }^{10}$ This communal self-image emerged around the middle of the nineteenth century among the Anglo-Welsh middle classes who dominated the public discourse about Welsh nationhood in its relation to Britain. Owing to their earlier contact and identification with prestigious English-language institutions, such as universities, the Anglican Church and government administration, the middle classes had to bridge the gap between rival concepts of social order. As a means of diverting attention from their participation in the strictly vertically hierarchical class culture of England, they exaggerated the egalitarian component of the gwerin in order to confirm their rightful belonging in the Welsh national community with its imagined horizontal structures. In other words, the discourse about the national community in Wales gradually replaced the prototypical gwerin-i.e. the self-educated, Welsh-speaking and Nonconformist rural communities-with an English-speaking urban middle class who demonstrated their Welshness by conforming to the morals and sensibilities defined by the English commissioners in their Reports. ${ }^{11}$ Spooner catches the problematic subtleties of the imagined egalitarianism as she subdivides her fictional villagers according to the distinct social groups recognized already by medieval Welsh law. These social groups used to be identified as the free bonheddwyr ("those who had bon or ancestry") and the unfree taeogion (the villeins); moreover, Country Landlords also features members of the "alltud-the incomer[s] from beyond the boundaries of Wales". ${ }^{12}$ The increased social mobility of the British populace in the first half of the nineteenth century had brought these three classes closer together than in previous centuries without erasing social rank entirely. Spooner's novel reflects these developments in the retained social stratification and illustrates the broadening definition of the imagined national community beyond the boundaries of the Welsh-speaking lower and peasant classes: her fictionalized 
gwerin simultaneously form an egalitarian community (Gemeinschaft) and a hierarchical society (Gesellschaft). ${ }^{13}$ Selecting, then, from a few romanticized, inoffensive peculiarities, Spooner thus endears Welsh Wales to an anglophone readership. More importantly, however, Country Landlords embraces a mid nineteenth-century Liberal ideology as it engages with the question of inherited moral duty among the nobility and gentry for the country and its people, while respecting the cultural distinctiveness of Wales at the Celtic periphery within the British union state. Consequently, the novel discards the dangers of political radicalism and republicanism in favour of Liberal ideals as the best form of governance in a multinational constitutional monarchy.

\section{Narrating liberalism: narrating a Welsh model village from an English point of view}

In the portrayal of the lives of the Welsh nobility and gentry, Country Landlords largely explores the idea of a national revival and employs a sentimental narrator to reach out to an English readership. ${ }^{14}$ Similar to Spooner's first novel, Gladys of Harlech, the narrator focuses on rivalries between noble families, and touches on the cultural split between Wales and England. The narrator assumes a godlike control over time and space, leaping through the years and occasionally interrupting the action to provide a historical context for various settings, thus making the protagonists' motivations comprehensible to the reader: "Many events have since taken place, and are to be found in the records of the town of Angharad. These shall simply be touched upon in connection with the narrative, before proceeding further" ${ }^{15}$ As a means of diverting attention from the story's fictional nature, the narrator also assumes the hindsight of the uninvolved historian: "To gloss over the trials sustained by the characters in the present narrative, and tint them with the couleur de rose, would be to paint an imperfect picture, to represent sunshine without shadows-the real would appear unreal" (3: 1). In combination with the historically verified failed rebellion in Italy in 1848, the pseudo-reality of the narration is subsequently rooted within recent living memory of mid nineteenth-century Britain.

The narrator propagates an account of the gwerin from above, wherein it is the duty of the bonheddwyr to provide the necessary means for the improvement of the living conditions of the disadvantaged taeogion. The social detachment from the lower classes is further corroborated in the portrayal of the inhabitants of Angharad, who, despite a certain knack for poaching, are represented as contented prisoners of their simple dwellings, living at the disposal of their social betters:

A small cottage at the instant came in sight, and, feeling painfully hungry, [the squire's son] stopped and entered the low doorway, in the hopes of obtaining a 
little refreshment. The inmate, a woman with a good-tempered smile, begged he would take a seat upon the settle, and she would in a few minutes make him a cup of tea, and give him the best of bread and butter. (1:219; my emphasis)

In the creation of this social dichotomy between action and reaction as a central force within the national community, the narrator follows a popular contemporary misconception of the Welsh peasantry as mired in deplorable living conditions and neglecting their livestock and farms if it were not for the altruistic intervention of the landed gentry. ${ }^{16}$ This fallacy not only betrays the narrator's othering of the wider populace in Wales, but also echoes Whig conceptualizations of British society and liberty, for, as Jonathan Parry points out, "[ $\mathrm{t}]$ he natural condition of a healthy society was for the propertied classes to rule". ${ }^{17}$ Only the concerted efforts of upper-class philanthropists advance the peasantry eventually, and so help the national community to move forward as one:

No more filthy alleys inviting pestilence and disease; no more broken panes stuffed with threadbare stockings; no more dirty doorways crowded with pigs, fowls, and ragged urchins, were discernible. The children were at their schools, the shattered casements were removed, and windows of a much larger dimension were inserted in their place. (3: 327)

In line with mid nineteenth-century Liberal ideals, the narrator measures the principal reward for social activism not in the economic increase of the landed gentry and nobility, but in an altruistic satisfaction gained from elevating the lower classes to a worthy life. Overall, the narrator shows little interest in a realistic portrayal of common rural life in Wales, as only very few and far between scenes show any interaction between tenants and landlords, let alone the daily life in the fictional village independent of the presence of the landed classes. In this position, the narrator betrays a disconnection from the social sphere of the Welsh peasantry. As R. J. Moore-Colyer points out:

[... the pursuit of high levels of profit was not [a Welsh farmer's] only consideration. To him, religious observance, bonds of kinship and standing in the community were of paramount significance and $[\ldots]$ the completion of a poem or essay for the local eisteddfod was every bit as important as producing abundant surpluses of wealth. ${ }^{18}$

Either through lack of awareness or deliberate obfuscation of these cultural particularities, the narrator of Country Landlords produces a Whiggish interpretation of the gwerin. While the hierarchy between landowners and tenants is at its most feudal, paradoxically, it results in the broadest attainable and, thus, egalitarian liberty which was founded on "the restraints and responsibilities of the rule of law" and "was not to be confused with licence". ${ }^{19}$ In other words, the quality of life among the common people of the land is entirely owed to the philanthropic undertakings of the ruling classes. 
Roberto M. Dainotto argues that regionalism or "the importance of space" emerged as a way of reading modern society in the anglophone novel in the British Isles during the nineteenth century, without constituting its own literary genre. ${ }^{20}$ However, Country Landlords, with its mostly Welsh setting, is not a regional novel. The fictional Angharad could easily be relocated to any rural area in mid nineteenth-century Britain, as the narrator first and foremost investigates social responsibility. By retreating behind a geographically unmarked terminology of local (self-)governance, the narrator extends the vision of an ideal society beyond the boundaries of the fictional Welsh estate and town to encompass the whole of real-life Britain:

[ ... ] everything thrives when men of property fulfil their calling. There are no more bigoted objections to innovations among the people. The sturdy fellows at the plough begin to patronise new farm-implements, which at an earlier period they scornfully rejected. The farmers agree among themselves that what their young landlord recommended and approved must be beneficial. (3:328)

This imagination of an ideal union between "men of property" and "sturdy fellows at the plough" already presents an anglicized revision of the gwerin, away from the sociocultural markedness of Wales in comparison to an unmarked England as the kingdom's cultural and political default. Spooner's narrator appears to espouse " $\mathrm{t}$ ] $\mathrm{he}$ emphasis of progressive thinkers in the $1850 \mathrm{~s}[\ldots]$ that the national community should be conceived in humane, cross-class, optimistic language", because the novel culminates in an idealistic description of a village recently roused from its former poverty under the leadership of a conscientious landlord. ${ }^{21}$

Despite the model character of this fictional Welsh village for any other village in the British Isles, social advance is persistently narrated as based on English virtues such as "[i]ndividual conscience, civic virtue, hard work, enterprise and respect for the law". ${ }^{22}$ Whilst the narrator aims at ameliorating the image of Wales as a semi-barbarous country in English-language fiction, in part this Anglocentric view of Welsh barbarity is confirmed involuntarily. Any of the described innovations in Angharad have been imported from beyond the border by a mature, less unapologetically Welsh Anarawd, and are implemented under his supervision. The narrator signals that Anarawd can only fulfil his role as the reformer because he has reached manhood during years spent at a distance from Wales: "Since Anarawd left Wales, he had acquired a military air, without losing his former pleasant address, but his youthful look was gone" (3: 81). The narrator praises Anarawd's eventual bicultural identity of Welsh feeling and English discipline, a blend which produces moral strength and makes him the perfect landowner as he balances Welsh patriotism with English dispassion for the benefit of his tenants. As Jane Aaron points out, to the contemporary reader of Country Landlords, Anarawd's choice to settle down on the Welsh estate "is ultimately more 
progressive, more to do with the real 'cry of the present day' in Wales, than any imperial glory". ${ }^{23}$ It is in this respect that the narrator mirrors the emerging national confidence in Wales just over a decade after the Reports, suggesting to the non-Welsh readership an alternative community principle in which bonheddwyr and taeogion are defined by mutual support instead of class rivalry. In addition, Anarawd and Gertrude's marriage constitutes a reversal of gendered imaginations of Wales as a feminine nation in opposition to the masculinized connotations regarding Englishness. ${ }^{24}$ Once he has surrendered his initial dangerously feminizing fancy of antiquarian studies whilst yet retaining a sober fondness for Wales, the Welsh Anarawd finds a perfect match in the English Gertrude, whose youthful bashfulness and determination have mellowed during her years of involuntary exile. Striking this balance, Spooner avoids narrating "a feminized (weak and subordinate) Wales $[\ldots]$ as 'married' to a masculine (strong and guiding) England". ${ }^{25}$

\section{Whigs and Tories: a novel in search for ideal local governance}

While Country Landlords clearly distinguishes between the Welsh and English populations as separate national communities, each with their own languages, lifestyles, customs and traditions, they are united under one common government. Aaron argues that "so overwhelming was the prestige of Great Britain as a modern, progressive and all-conquering imperial nation-state, that $[\ldots]$ these embryo nation-builders [...] were, in part, following English value systems" ${ }^{26}$ In the same way, Spooner devises Britishness as a supranational identity that can only be contained in a union state made up of equal partners. However, this equality is problematic owing to the narrative's general Anglocentric outlook, not to mention the perpetuation of imperial Britain's undisputed supremacy over its colonial possessions, country and people alike, which is most prominently on display in the stereotyped portrayal of Lewis's Patois-speaking Black servant, Yarico. ${ }^{27}$

This does not mean that the novel rejects contemporary republicanism outright or embraces imperialism. To the contrary, "the glory of empire is consistently disparaged [...] particularly through the actions and sayings" of Captain Lewis. ${ }^{28}$ At the climax of the novel, he redeems himself by demonstrating his loyalty to the Risorgimento and their fight against the Papal States in May 1848. In essence, his death anachronistically reflects Whig ideology of the late 1850s, which was directed "against the four faces of autocracy [ ... ]Austria, Russia, Napoleon III and the Pope". ${ }^{29}$ The stylization of Ricardo Lewis as a "noble gentleman" strictly follows Spooner's Liberal conceptualization of the gwerin as "an optimistic term referring to the progress of the common folk of Wales coming to the fore in the 1840s and 1850s, after centuries of passivity and mute obedience to Welsh squire and parson". ${ }^{30}$ Lewis therefore sees himself as "the encourager of industry and the promoter of 
knowledge"; his part-Italian background and progressive ideology are ultimately expressed in the architecture of his new mansion in the style of the "Italian villa, except that it was much more massy and baronial-looking" $(1: 63,64)$. In Lewis, the civic duty of the responsible landlord merges with the democratic idealism of making education available for all, peasantry and women alike, going even so far as dismissing Gertrude's governess and overseeing her classical education himself $(1: 66-67,103)$. In that sense, Lewis's pursuits echo developments in Wales during the first half of the nineteenth century with the establishment of schools through private efforts, as was the case with Lady Charlotte Guest's exemplary provision of basic schooling in Dowlais. ${ }^{31}$ The literary philanthropist and school-founder Lewis may therefore be lacking a noble ancestry, but his social activism, which he finances through his successful economic endeavours, should in theory predestine him as the ideal landlord: "I would have done a great deal for [the people of Angharad] if they would have let me, or rather if Mr. Gwynne had not put a clog to the wheel whenever I made the attempt" (2: 236).

Concerning his own family, however, Captain Lewis's loving but essentially tyrannical hold on Gertrude blots his otherwise noble character as he forbids her to marry Anarawd. This decision appears paradoxical, since Anarawd is of Welsh descent and has a great antiquarian interest in Welsh history. These qualities should naturally establish him as an ideal match for Gertrude, whose Englishness Lewis has tried to obliterate by raising her in Wales. However, he is irrationally convinced that Anarawd shares his father's abhorrence for all things Welsh and would thus corrupt the young woman: "If [Lewis] could only know [Anarawd's] character truly, he would be reconciled to him; they would be friends, and the country would benefit by their united exertions" (2: 237). It is against this type of intranational antagonism, then, that Lewis's involvement in the Italian Risorgimento has to be re-evaluated. Before his death on the Naples barricades, he realizes that preventing the marriage between Gertrude and Anarawd for fear of losing her to a rival squire mirrors the Italian situation:

Honour, Gertrude, I dare not sacrifice my honour. Having joined this anarchical society, so the enemies of freedom denominate all freedom of thought and deed-having sworn to support the cause of human right in this oppressed country, I dare not retract. [ ... ] My last breath will be a prayer for your happiness. (3: 132)

Spooner appropriates Giuseppe Mazzini's Young Italy movement to comment on Welsh tribalism. Lewis eventually sees the error of his ways thanks to his involvement with the Risorgimento, as he contributes to the unification of a fractioned Italian national community.

In contrast to Ricardo Lewis, Anarawd's father, Owen Herbert Gwynne, recalls the Irish steward Sir Kit Rackrent in Maria Edgeworth's Castle 
Rackrent (1800), for he embodies the archetype of a negligent absentee landlord who spends most of his time and money across the border in England. His indifference to home affairs and lack of "interest in anything but self-indulgence" betray themselves in the appearance of the Bleddyn estate (1: 62). The grounds and manor are truly Gothic, as the ancestral home has fallen into disrepair; the estate externalizes its owner's indifferent character as nature slowly creeps up on the man-made structures: "the glass door opening upon the gravel walk, its passage choked with sickly flowers, evergreens, and overgrown vegetation" (1: 41). ${ }^{32}$ On the few occasions when Gwynne does visit his Welsh home, he ridicules and terrorizes his family. He is thus less of a father to Anarawd than Captain Lewis is to Gertrude, whom he has effectively abducted. Gwynne's fixation on England results in his complete division from his ancestral land and its people, who, in return, show nothing but contempt for him: "I tell the truth, he was different to what he is now; he go among those strangers, and come back here, and think his countrymen can't do nothing", one of the Angharad locals complains (1: 17).

With the juxtaposition of the landlords Lewis and Gwynne, Spooner breaks with the tradition of configuring the gwerin along ethnic fault lines. Country Landlords reimagines the Welsh nation as a community defined by a shared set of values in which each social group fulfils their respective duty for the benefit of all. Aaron argues that Lewis represents the ideal Welsh landlord, as he has succeeded in the improvement of Angharad where Gwynne has failed. ${ }^{33}$ However, Lewis's unapologetic Welshness and Italian republicanism, which to the post-1850s British mindset carry dangerous notions of political radicalism, manifest themselves as antagonism towards Englishness and the Crown, which ultimately disqualifies him when put into the broader perspective of the British union state. ${ }^{34}$ Ultimately, Lewis's Anglophobia catches up with him when he is betrayed to his death by an English enemy, Lord Morlif, and Gwynne also fades away due to his prodigal lifestyle (3: 138-39; 2: 72). Although Gwynne's Welshness is entirely inoffensive along cultural as well as political fault lines, his squandering lifestyle disqualifies him as a pillar of British society. Ultimately, it is Anarawd Gwynne who emerges as the perfect Welsh landlord because he successfully unites Welsh heart and English military discipline for the benefit of the local population.

\section{Bicultural protagonists: displaced heroes and kidnapped heroines}

The central characters in Spooner's entire body of work are uniformly set among the Welsh upper classes, and their attitudes towards the peasantry are utilized as examples of good and bad landownership. The sociopolitical configuration and emplotment of the heroes and villains mark Country Landlords as a romance in which the historically verified Risorgimento links with 
the fictional protagonists' quests to improve the social conditions of the gwerin. ${ }^{35}$ The story unfolds in a diachronic manner, focusing on the structural transformation of Welsh society thanks to country estates which are ideologically rooted in a pre-modern Wales independent from an Anglocentric state. The conflict between Robert Lewis and Owen Herbert Gwynne links cultural identity with matters of class responsibility, examining "what kind of leader, or landlord, [...] Wales need[s]". ${ }^{36}$ Anarawd and Gertrude are caught between the personal antagonism of their fathers, who represent the two opposite poles of the Welsh squirearchy-namely, the ancient aristocracy and the comparatively recent bourgeoisie. Although the eventual marital union between Gertrude and Anarawd serves as an entirely idealized example for the perfect Welsh bonheddwyr, Spooner presents this state of perfection as resulting from beneficial anglicization acting as a counterweight to expressions of unbridled Welshness. The resulting biculturation signifies a positive force because it unites positive traits of both language cultures, such as English formal learning and a Welsh sense of community, and exercises control over identified deficiencies-namely, the abandon in English conspicuous consumption or Welsh nostalgia. This Anglo-Welsh power play is carried out in the character development of Anarawd Gwynne.

Disenchanted by city life as well as feeling estranged from his father, Anarawd finds personal freedom in the location of his ancestral home: "I am charmed to be once more in Wales. I feel free again. I can now climb the hills $[\ldots]$ and enjoy life. I don't believe I could support another London season" (1: 107). Additionally, he orientates himself in terms of Wales's distant past in his antiquarian studies and the desire to learn the Welsh language (1: 52-53). Anarawd's studies are encouraged by his mother, but she also urges him not to neglect his formal-read Englishschooling (1: 53-54). Even though his antiquarian studies serve first and foremost as an escape mechanism that aligns him with a narrowly defined geographical location, they also allow Anarawd to establish a common ground with his tenants. To some measure, Anarawd thus turns into a fictional foil for the contemporary, English-born Lady Augusta Hall of Llanover (180296), who was a great patron of the arts and antiquarian studies in Wales, and held her personal pseudo-medieval court at Llanover Hall. ${ }^{37}$ Spooner may be criticized for stereotyping the majority of her peasant characters as stubborn layabouts, but her representation of relations between workers and paternalistic landowners is acutely rooted in the realities of life in north-west Wales during the first half of the nineteenth century:

[ ... ] where tenants were prepared to emulate systems adopted by their landlords, they would have been more likely to take notice of a Welsh-speaking resident squire whose interests were closer to their own than of an absentee proprietor whose instructions were executed by an English or Scottish agent. ${ }^{38}$ 
Additionally, landowners such as the Wynnes of Peniarth and the Nanneys of Gwynfryn continued the use of the Welsh language in their families in order to engage with their almost entirely Welsh-speaking tenants. ${ }^{39}$ However, before the fictional Anarawd can employ his cultural knowledge and language skills to improve the living conditions of his tenants, his role as a responsible landowner also demands a higher education that provides him with an epistemic order for his unsystematic and, therefore, aimless antiquarian endeavours.

The balance between the two areas of knowledge follows the imagination of the ideal English gentleman who is not an expert in a narrowly defined field of study, but possesses a broad overview of a great number of subjects. In these instances, Anarawd resembles Ricardo Lewis; what places him above the rebellious Italo-Welsh captain, however, is his proven loyalty to the British union state by having fulfilled his duty in the English army at home and abroad (2: 198-200). Analysing perceptions of place and time, Doreen Massey draws attention to ideologies that reject local rootedness "as a retreat from the (actually unavoidable) dynamic and change of 'real life"' and defines belonging as "romanticised escapism from the real business of the world" ${ }^{40}$ Likewise, Dainotto stresses that "Critical Regionalism [ ... ] believes $[\ldots]$, in a quite uncritical way, in the survival of past traditions and 'old roots' still available to a 'contemporary culture"' ${ }^{41}$ Therefore, societal norms force the regionalist Anarawd to mature into a respectable British subject through his service in the army, although he takes up his commission only reluctantly. His tenure as an army officer banishes him from his homeland for a considerable time, as he has to travel the breadth and length of the British Empire. As a direct consequence, Anarawd learns to appreciate place as a process "conceptualised in terms of the social interactions" instead of an object, "motionless, frozen in time". ${ }^{42}$ When he eventually reunites with Gertrude, he has matured into the responsible landlord who no longer seeks escape in the past because he cannot face the present. To the contrary, he even continues Captain Lewis's social reform projects for Angharad.

Spooner further contests the image of a shameful Welsh femininity as propagated by the condescending Anglocentric paternalism of the "Blue Books" as Gertrude's identification with Wales functions as a moral corrective to her English birth. Her emplacement tallies with the conventions of the romance genre and mirrors Anarawd's fate as Gertrude's idealized life on the fictional estate in Wales is juxtaposed with her trials and tribulations suffered in the very real settings of London and Naples, during which she proves her constancy of character. ${ }^{43}$ Even before she falls out with her rediscovered relatives in England, she feels weary of the English nobility due to their antagonism towards the Welsh peasantry $(1: 267,280)$. The Anglican faith represents the only comforting form of Englishness in Gertrude's life, and she attempts to share its uplifting strength with the gwerin by sponsoring a new church building for Angharad, much to Captain Lewis's surprise: 
"What! a church, Gertrude? A chapel would be far more appreciated. You forget what chapel-goers the Welsh are."

"Yes, but you know the reason: there are so few churches, and a sad dearth of energetic pastors. Were we to build more churches, and have some earnest, disinterested men, who would not neglect their parishes, I feel convinced the chapels would quickly diminish." (2: 263-64; my emphasis)

Gertrude's attitude is decidedly Liberal Anglican as she criticizes specifically those divisive sociopolitical dimensions within the Church of England that delineate "national religion in narrowly and divisively sectional terms". ${ }^{44}$ Gertrude thus insinuates that it is due to the Anglican clergy's disinterest in their parishioners' lives that Welsh chapels thrive. Spooner again draws from a great number of contemporary discussions of and controversies about clerical care in Wales, particularly where the Church of England is concerned. For example, Alfred Ollivant became the newly appointed bishop of Llandaff in 1850, despite being unable to converse with his parishioners in Welsh and remaining a resident of Cambridge instead of moving to his new bishopric. ${ }^{45}$ Gertrude's liberalism directly derives from the idea of a nurturing and caring gentry for the benefit of all Britons. However, her intervention also presents a case of "internal colonialism" because she exerts the sociocultural dominance of her anglicized class over the Welsh villagers, which then gives "English cultural forms super-ordinate status within the societies of the Celtic fringe". 46 As Geraint H. Jenkins points out, by "stimulat[ing] literacy among the young and old" in Sunday school, organizing eisteddfodau and hymnsinging festivals, as well as encouraging sobriety, "Nonconformity encouraged upward social mobility". 47 However, with her sponsorship of an Anglican church for Angharad, Gertrude dismisses any existing agency among the villagers:

They want arousing to a sense of their wretched condition. As long as they can fill their mouths with oat-cake and potatoes, they are contented. They are indeed in a half-savage state. We must civilize them. They must be educated. (2: 270)

Owing to her hegemonic position in the social field, Gertrude privileges the institution closest to herself and against the demands and actual needs of the Welsh lower classes. As well meaning as Gertrude is towards the inhabitants of Angharad, she unwittingly follows in their othering as Celtic savages. Her privileged, anglicized lifestyle thus forms the root of her judgement as she envisions the villagers as incapable children of nature who rely on the explicit guidance of their local squirearchy. On the one hand, the novel disparages British imperialism and the dominance of the English nobility. ${ }^{48}$ On the other hand, however, Spooner unintentionally employs the language of the English colonizer in Gertrude's verdict on the Welsh peasantry, despite displaying a generally positive attitude towards the literary representation of the 
Cymry Cymraeg. Since Gertrude functions as a positively connoted interface between the English readership and the Welsh narrated subject, her actions and the ambiguous colonial language reflect mainstream attitudes towards social reform programmes in Wales after an English cultural model.

\section{Conclusion}

The literary representation of Welsh community life in Country Landlords derives from middle-class perceptions of the national community in the 1850s and 1860s, and indicates a beginning diversification in the imagination of the gwerin. The gwerin are reinvented as a national community defined by a shared set of values in which the different social groups fulfil their respective duties for the benefit of the community and, ultimately, the whole nation. Hailing from a family of English immigrants to Wales, Spooner's personal background provides the ideology on which the narration of protagonists from both sides of the Anglo-Welsh border is founded. Although Spooner's narrator distinctly remains apart from identifying with the Welsh nation on an ethnic basis, s/he engages in cultural translation and encourages anglophone readers to readjust their view of Wales as a marginal region. With the two lovers-the English-born Gertrude Fitzhammons and the Welsh Anarawd Gwynne-Spooner breaks through the imagination of the Cymry as an ethnic group. Country Landlords engages in "Union Nationalism" by aligning itself with Wales as a culturally distinct region, but all the same presenting it "as a contributory nation to a greater Britain ruled by the English monarchy, rather than as a potentially sovereign nation justified in seeking its independence". ${ }^{49}$ Louisa Matilda Spooner offers a literary exploration of responsible guardianship over Wales and its people at a time when the Welsh national community faced institutionalized ridicule and denigration chiefly from the direction of England. By integrating (Italo-)Welsh aristocrats into rural communities at a great distance from London, Spooner affords Wales a more central position in historical as well as mid-Victorian Britain.

\section{Notes}

1. Spooner may also be the author of a novel called Rich and Poor (1859), based on Charles J. Skeet's publishing announcement. See Charles J. Skeet, "Literary Notes of the Week", The Leader, 22 Oct. 1859: 1181. However, no further information can be obtained about this novel and it may even well be the case that the announcement could refer to Country Landlords, which was published the following year but by Spooner's new publisher, T. Cautley Newby, who also released her third known novel, The Welsh Heiress (1868).

2. Jane Aaron identifies her dates of birth and death as 1821-90. See Jane Aaron, Nineteenth-Century Women's Writing in Wales: Nation, Gender and Identity (Cardiff: U of Wales P, 2010), p. 115. Other sources, however, deviate from 
those years. A detailed family tree for the Spooner family presents her life dates as 1820-86. See D. H. W., "Family Tree of the Swinton Spooners", Ffestiniog Railway Magazine, 1977: 21. The date of death is further corroborated in a public notice placed in the London Gazette in 1887 by Spooner's solicitors, Bloxham and Son, who present the day of her death as 5 December 1886. See Bloxham and Son, "Louisa Matilda Spooner, Deceased", London Gazette, 28 June 1887: 3516.

3. Gareth Elwyn Jones and Gordon Wynne Roderick, “'Treason' and Its Aftermath, 1847-1870", A History of Education in Wales (Cardiff: U of Wales P, 2003), pp. 56-74 (57).

4. As Gwyneth Tyson Roberts points out, prior to the publication of the Reports, the Welsh "were prepared to hear that they were poorly educated; they had not expected to be told that they were drunken, dirty, superstitious and sexually promiscuous liars and cheats". See Gwyneth Tyson Roberts, The Language of the Blue Books: Wales and Colonial Prejudice (1998; Cardiff: U of Wales P, 2011), p. 209. The commissioners' skewed view of Welsh community life reproduced Anglocentric hetero-stereotypes of the population in Wales as an ethnically inferior Celtic nation with next to no regard for Christian morality, which inevitably contributed to the high levels of poverty and childbirth out of wedlock. The commissioners traced these failings back to the still widely spoken Welsh language and Nonconformism: "Above all was the want of chastity in the women which resulted from the practice of 'bundling' and much increased by night prayer meetings and the intercourse which ensues in returning home"'. Therefore, the Reports arrived at the conclusion that, as long as all three fields of influence remained unchecked, Wales would remain an ungovernable and ignorant region, and a burden to Britain in general and to England especially. See Ieuan Gwynedd Jones, Mid-Victorian Wales: The Observers and the Observed (Cardiff: U of Wales P, 1992), pp. 143, 137.

5. Jones and Roderick, p. 60.

6. Kirsti Bohata, Postcolonialism Revisited: Writing Wales in English (Cardiff: U of Wales P, 2004), p. 62.

7. "Reviews", Cambrian Journal, 1858: 158-60 (158-59). See [Louisa Matilda Spooner], Gladys of Harlech; or, The Sacrifice, 3 vols. (London: Charles J. Skeet, 1858).

8. [Geraldine Endsor Jewsbury], "New Novels", Athenæeum, 7 July 1860: 15.

9. See Philip Jenkins, A History of Modern Wales, 1536-1990 (London: Routledge, 1997), p. 61.

10. Susan Pitchford has highlighted the general difficulty of translating the Welsh gwerin into English, and further stresses that, in nineteenth-century Wales, the term evolved from a more rural conceputalization of the national community to include a much wider demography: "The word has no English equivalent [ ... ] though 'common folk' is a fair translation. The gwerin acquired a symbolic significance as an expression of Welsh national identity during the late 19th century; originally a rural type, industrial workers were included as a kind of extended family. The term evokes a noble if simple people forming a classless and unified community". See Susan Pitchford, Identity Tourism: Imaging and Imagining the Nation (Bingley: Emerald, 2008), p. 24.

11. Gwyn A. Williams, When Was Wales? A History of the Welsh (London: Penguin, 1991), p. 237.

12. John Davies, A History of Wales, 5th ed. (London: Penguin, 2007), pp. 87, 88. 
13. Ferdinand Tönnies differentiates between Gesellschaft ("society"), as oriented towards individualism and negotiation, and Gemeinschaft ("community"), as oriented towards community and reciprocity. See Michael Opielka, Gemeinschaft: Soziologie nach Hegel und Parsons, 2nd rev. ed. (Wiesbaden: VS Verlag für Sozialwissenschaften, 2006), pp. 29, 33.

14. Aaron, p. 116.

15. S[pooner], L[ouisa] M[atilda], Country Landlords, 3 vols. (London: T. C. Newby, 1860), vol. 1, p. 61. Subsequent references are cited parenthetically by volume and page number, and are to this edition.

16. R. J. Moore-Colyer, "Landowners, Farmers and Language in the Nineteenth Century", The Welsh Language and Its Social Domains, 1801-1911, ed. Geraint H. Jenkins (Cardiff: U of Wales P, 2000), pp. 101-30 (107-08).

17. Jonathan Parry, The Politics of Patriotism: English Liberalism, National Identity and Europe, 1830-1886 (Cambridge: Cambridge UP, 2006), p. 51.

18. Moore-Colyer, p. 109.

19. Parry, pp. 49, 50.

20. Roberto M. Dainotto, Place in Literature: Regions, Cultures, Communities (Ithaca: Cornell UP, 2000), pp. 28, 30.

21. Parry, p. 99.

22. Parry, p. 62.

23. Aaron, p. 117.

24. Bohata, p. 72.

25. Bohata, p. 72.

26. Aaron, p. 80.

27. Yarico's civic status remains ambivalent throughout the novel. On the one hand, she is a greatly respected member of Lewis's domestic staff, and Gertrude depends on her greatly for emotional support (see 2: 28, 122-25). On the other hand, neither Yarico nor Gertrude corrects Lady Strangford when she calls Yarico a slave as late as the 1840s; this constitutes an anachronism in light of the British Slavery Abolition Act of 1833 (see 1: 49, 52).

28. Aaron, p. 117.

29. Parry, p. 223.

30. Prys Morgan, "The Gwerin of Wales-Myth and Reality", The Welsh and Their Country: Selected Readings in the Social Sciences, ed. Ian Hume and W. T. R. Pryce (Llandysul: Gomer, 1986), pp. 134-52 (135).

31. Jones and Roderick, pp. 60-61; Moore-Colyer, p. 120.

32. Spooner's fictional landscapes generally appear to exist in a symbiotic relationship with their respective owners, as a similar fate awaits Captain Lewis's estate after his flight from Britain into Italian exile: "the shutters were either wholly or partially closed, and the creepers hung loose from the sides of the house, falling in ungraceful festoons. [ ... ] Grass and weeds thriving in the gravel, dead leaves and boughs strewed from end to end in profusion. [... ] What a wilderness! what dreariness! Poor Lewis!” (3: 88).

33. Aaron, p. 118.

34. Parry, p. 233.

35. Hayden White, Metahistory: The Historical Imagination in Nineteenth-Century Europe, 11th ed. (Baltimore: Johns Hopkins UP, 1978), pp. 8, 10.

36. Aaron, p. 116.

37. Davies, p. 376; "Meeting of Welsh Harpers at Llanover", Aberystwyth Times, Cardiganshire Chronicle, and Merionethshire News, 23 Oct. 1869: 3. 
38. Moore-Colyer, p. 111. Interestingly, Country Landlords opens with a night-time scene in a guest house in Angharad and the arrival of a Scottish farming agent acting on behalf of the disinterested, absentee landlord, Owen Herbert Gwynne, who is instantly rebuffed by a Welsh farmer for his compliance (see 1:7-8, 16-17).

39. Moore-Colyer, p. 119.

40. Doreen Massey, “A Global Sense of Place”, Marxism Today, June 1991: 24-29 (26).

41. Dainotto, p. 17.

42. Massey, 29.

43. Emplacement "constitutes a character's relational position in a symbolically charged geography" and "determines the power dynamics between individual characters and their communities". See Rita Singer, "Bicultural Geographies: Narrating Anglo-Welsh Identities in the Novels of Allen Raine", International Journal of Welsh Writing in English, 3.1 (2015): 102-22 (102-03); Franco Moretti, Atlas of the European Novel, 1800-1900 (London: Verso, 2009), p. 18.

44. Parry, p. 96.

45. Roger L. Brown, "In Pursuit of a Welsh Episcopate", Religion and National Identity: Wales and Scotland, c. 1700-2000, ed. Robert Pope (Cardiff: U of Wales P, 2001), pp. 84-102 (84-85).

46. Michael Hechter, Internal Colonialism: The Celtic Fringe in British National Development; with a New Introduction and Appendix by the Author (New Brunswick, NJ: Transaction, 1999), p. 109.

47. Geraint H. Jenkins, A Concise History of Wales (Cambridge: Cambridge UP, 2007), pp. 208, 210.

48. Aaron, p. 117.

49. Thomas Phillips, qtd. in Aaron, p. 72. See Chris Williams, "Problematizing Wales: An Exploration in Historiography and Postcoloniality", Postcolonial Wales, ed. Jane Aaron and Chris Williams (Cardiff: U of Wales P, 2005), pp. 3-22 (6).

\section{Disclosure statement}

No potential conflict of interest was reported by the author.

\section{ORCID}

Rita Singer (D) http://orcid.org/0000-0002-9803-3163 


\title{
"OUR POOR LAND OF WALES": NATIONAL IDENTITY AND NATIONAL HEROISM IN WOMEN'S HISTORICAL FICTIONS
}

\author{
Diana Wallace
}

\begin{abstract}
This essay examines a selection of nineteenth- and early twentieth-century historical fictions by anglophone Welsh women writers and other women writers sympathetic to Wales, focusing on Emma Robinson's Owen Tudor: An Historical Romance (1849), L. M. Spooner's Gladys of Harlech; or, The Sacrifice. A Romance of Welsh History (1858), Elizabeth Gaskell's "The Doom of the Griffiths" (1858) and Allen Raine's Hearts of Wales: An Old Romance (1905). Both women and Wales have been notably absent from theorizations of the development of the historical novel, in part because the focus on the work of Sir Walter Scott has led to an emphasis on an Anglo-Scottish model. In contrast, this essay explores the way that these women writers represent Wales in order to reshape narratives of national identity and explore notions of male and female heroism. All four writers invoke the figure of Owain Glyndwir as the leader of the last major rebellion against the English, while two also feature the figures of Owen Tudor and Henry Tudor as the founders of the Tudor dynasty. They examine the national and personal consequences of betrayal and defeat. Excluded from mainstream historiography, these female writers turn to other modes of writing in order to reinsert both women and Wales into history.
\end{abstract}

Once upon a time, and that a long time ago, when our poor land of Wales lay torn and bleeding in the throes of her last struggle for independence $\ldots{ }^{1}$

With this emotive opening, Allen Raine sets her historical novel Hearts of Wales: An Old Romance (1905) against one of the most iconic moments in Welsh history: the rebellion against the English between 1400 and 1415 led by Owain Glyndŵr (or Owen Glendower as Shakespeare calls him in Henry $I V$, Part I) - the last attempt to establish an independent Wales before the Cymru Fydd movement of the late nineteenth century. Despite the initially formulaic fairy-tale opening, Raine is invoking real history here. It is a history of violent defeat and conquest, yet her use of the pronoun "our" suggests her unequivocal partisanship in that national struggle. Hearts of 
Wales is part of a neglected body of historical novels and stories by women writers who use fiction to intervene in the written history of Wales and create alternative stories of nationhood. They focus with particular intensity on this narrative of national defeat epitomized by Glyndŵr's failed rebellion, using it to create space for a consideration of female national identity and heroism. Another connected space is opened up by the use of the more ambiguously heroic figures of Owen Tudor and his grandson, Henry Tudor (later Henry VII), as the Welsh founders of a British Tudor dynasty. Excluded from mainstream historiography, these female writers turn to other modes of writing-particularly romance and the Gothic-in order to reinsert both women and Wales into historiography and thus reinvent British history.

In this essay, I want to focus on four texts which use historical fiction actively to reshape national and political narratives about Wales: Emma Robinson's Owen Tudor: An Historical Romance (1849), L. M. S. (Louisa Matilda Spooner)'s Gladys of Harlech; or, The Sacrifice. A Romance of Welsh History (1858), Elizabeth Gaskell's "The Doom of the Griffiths" (1858) and Raine's Hearts of Wales. ${ }^{2}$ All four texts are haunted by the failure of Owain Glyndŵr's rebellion and the notion of Wales as a defeated and conquered country. As one character puts it in Gladys of Harlech: "we are forced to acknowledge that a yoke binds us to a foreign power. We are a conquered people" (1: 10). These texts are thus concerned with questions of national identity and heroism (both male and female), and with the public and private consequences of betrayal and defeat. Raine uses the national struggle as a background to counterpoint the theme of family betrayal in a classic female Gothic plot concerning the disinheritance of her heroine, Eleri of Garth. Setting their texts a generation or so after the rebellion, Robinson and Spooner depict Owen Tudor and Henry Tudor, respectively, as founders of the Tudor dynasty, which restores Wales to a more central role within the United Kingdom. Like Raine, Spooner's major focus is on female disinheritance, as her heroine Gladys is imprisoned by the "Saxon" usurper within the castle which should be her birthright. Finally, Gaskell's text traces the consequences of the betrayal of Glendower even further down the ages as his curse plays out in the ninth generation of the Griffiths, the fall of the family mirroring that of the nation. All four texts are thus concerned with the question of inheritance: the disinheritance of women within patriarchy is paralleled with the subjugation of the Welsh within the unequal "union" of Wales and England.

Both women and Wales have been notably absent from theorizations of the development of the historical novel until recently. Since Walter Scott has traditionally been seen as the progenitor of what Georg Lukács in his seminal study called the "classical historical novel", Scotland has fared better in discussions of the ways in which historical fictions have engaged with and shaped debates about national identity. ${ }^{3}$ Scott's Waverley (1814) has been taken as 
the prototype, with the marriage of Edward Waverley and Rose Bradwardine figuring the dialectical union of England and Scotland. Critical accounts of the genre from Avrom Fleishman's The English Historical Novel (1971) through to Jerome de Groot's The Historical Novel (2010) have focused on this Anglo-Scottish-centric model, although de Groot acknowledges the importance of women writers. ${ }^{4}$ While Richard Maxwell's The Historical Novel in Europe, 1650-1950 (2009) and Anne H. Stevens' British Historical Fiction before Scott (2010) draw attention to earlier historical fictions, both centralize Scott, and Maxwell argues for a "Franco-Scottish" model for historical fiction. ${ }^{5}$

Anglophone Welsh historical fictions, perhaps particularly those by nineteenth-century women writers, do not fit the critical paradigms currently available. While Katie Trumpener in Bardic Nationalism: The Romantic Novel and the British Empire (1997) draws attention to the contributions of female, Irish and Scottish novelists to the national tale (a form closely connected to the historical novel), ${ }^{6}$ for instance, Jane Aaron has noted that she barely mentions Wales or Welsh authors. As Aaron suggests: "it is more difficult to find [fictions] focusing on the type of aspiring nationhood that [Trumpener] ascribes to the Scottish and Irish fictions of the period"? More recently, a special issue of Women's Writing on Romantic Women Writers and the Fictions of History (2012), edited by Fiona Price, offers excellent essays on writers such as Jane Porter and Joanna Baillie but includes no comparable Welsh figures. Other than in Aaron's writings, ${ }^{8}$ anglophone Welsh women's historical fiction has tended to be ignored.

Not surprisingly, all four of the texts discussed here are influenced by the work of Sir Walter Scott; as John Henry Raleigh puts it: "To have been alive and literate in the nineteenth century was to have been affected in some way by the Waverley novels". ${ }^{9}$ Gaskell's historical fictions follow the Scott model, where "opposing forces in times of turmoil are represented by 'typical' characters". ${ }^{10}$ More unexpected is Scott's influence on Allen Raine, who was given "a complete set of the Waverley novels" when she was young, "which she immediately read straight through". ${ }^{11}$ At the level of plot, character, narrative voice and paratextual apparatus, these texts rework the Scott tradition for a specifically Welsh context and in order to encompass a female national identity.

Both Spooner and Raine preface their texts with introductory notes reminiscent of those used by Scott (such as the "Introductory" to Waverley), which suggests that, like Scott, they were conscious that they were remaking a genre and functioning as an interpreter or mediator for (English) readers likely to be unfamiliar with the history, culture and language of Wales. In her prefatory note, Spooner comments: "The subject is somewhat new" (1:2). The narrative originated, she tells us, "in a strong love of country on the author's part, and a wish to extend a knowledge of its mountain lands, characteristics, traditions, 
prejudices, and superstitions, at a remarkable period of our island history" (1: 2). Spooner's avowed partisanship and desire to educate her reader about her country are likely to be part of the strong defensive reaction in Wales to the 1847 Report into the State of Education in Wales (popularly known as "Brad y Llyfrau Gleision" or "The Treachery of the Blue Books"). The Report depicted the Welsh as dirty, uneducated, superstitious and promiscuous, and blamed their primitiveness on their continuing use of the Welsh language. ${ }^{12}$ Spooner's idealization of her sensitive, intelligent and pure heroine, Gladys, counters the Report's perceived slurs against Welsh womanhood.

Half a century later, Raine is writing in the aftermath of the failure of the 1890s Welsh Home Rule movement, Cymru Fydd. Her preface disclaims any pretensions to "historical accuracy", but is particular about the authenticity of the language, commenting: "The fact that all classes at that time conversed in the vernacular $[\ldots]$ must be the author's excuse for having retained some Welsh words and phrases which she found it impossible to express in the English language" (7). Like Scott, both Spooner and Raine use footnotes or endnotes to provide English translations, explain customs and beliefs (such as sin-eating), and give historical sources, both written and oral. While Raine's notes emphasize oral history-such as Professor Evans's memory of seeing the last sin-eater in South Wales around 1825 (192)—Spooner cites sources such as "Warrington's History of Wales" (1:255) or "The Beauties of Wales, by the Rev J. Evans" (2: 203), which suggest to the reader that her fiction is grounded in historical (or at least antiquarian) research.

Gaskell and Robinson adopt a less formal but nevertheless consciously mediatory role. Although English, Gaskell had important emotional ties to Wales: she honeymooned and frequently holidayed at her uncle's home in North Wales, and her only son died there in 1845 . While she does not include a formal prefatory note to "The Doom of the Griffiths", her narrator's opening comments-"I have always been much interested by the traditions which are scattered up and down North Wales relating to Owen Glendower (Owain Glendwr is the national spelling of the name)" (103)-serve a similar function. As Gaskell implies, the chosen spelling of Glyndŵr's name itself indicates a writer's own national sympathies. ${ }^{13}$ Gaskell's own empathy with Welsh patriotism-"I fully enter into the feeling which makes the Welsh peasant still look upon [Glendower] as the hero of his country", her narrator comments (103)-is less surprising in the light of her Unitarianism and her repeated championing of the underdog. Her engagement with the country is indicated by parenthetical translations of Welsh, including a triad (117), and references to Welsh customs.

Of the four writers discussed here, Robinson (the daughter of a London bookseller) is the least partisan in her approach, with a tendency to present the Welsh as heroic but exotic primitives. Her introductory comments adopt the perspective of the tourist guide, leading travellers to Penmynydd 
in Anglesey, where the dwelling of the Tudors "has shrunk into an inconsiderable farm-house!" (4). Assuming that her readers will be monoglot English speakers, she reassures them: "we beseech the reader not to be daunted by the appearance of the word, but to pronounce it boldly as if the y's were u's" (4). The bleak present-day landscape, she tells us, has its roots in the "ruin and desolation" left by the "long wars between the Welsh and their Anglo-Norman invaders which closed so many years before the suppression of the great rebellion of Glendower" (5).

Within the Welsh anglophone tradition, Glyndŵr's failed rebellion occupies a similar place to the 1745 Jacobite rebellion in Scott's fiction. It is a moment of (lost) possibility in the forging of a Welsh identity which haunts the national imagination. Owain Glyndŵr is a more heroic figure than Charles Edward Stuart. In the words of Shakespeare quoted by Gaskell, Glendower is a magical figure whose birth was marked by a sky "full of fiery shapes / Of burning cressets", and who claims that he "can call spirits from the vasty deep" (103). ${ }^{14}$ Shakespeare's history plays are equally important intertexts for Robinson's presentation of Glendower as a "wizard prince" (11) and the future Henry V as a "gay young wassailer" who overthrows him (12). Linked with Glyndwir is the prophecy, or curse, which is an important motif in all four of the texts discussed here. In Gaskell's story, the "doom" which Glendower passes on Rhys ap Gryfydd, his "more than brother" who consented to his leader's betrayal, curses his "race" through nine generations: "In those days the last male of thy race shall avenge me. The son shall slay the father" (104). When the prophecy is fulfilled and the last Griffiths son does, indeed, kill his father, the final lines of the story suggest a national symbolism: "The house of Bodowen has sunk into damp, dark ruins; and a Saxon stranger holds the lands of the Griffiths" (138). As Aaron comments, this single family functions as symbolic of "a race, which was doomed to annihilation by its betrayal of its own freedom-fighters". ${ }^{15}$

The prophecy has a particular teleological force in historical fiction, where it foregrounds narrative hindsight. For the reader, aware that Glyndwor's rebellion fails or that Owen Tudor will found the famous Tudor dynasty, it figures that uncanny sense that we already know the ending, which is thus predestined in narrative terms. Raine invokes this sense of foreknowledge early in Hearts of Wales when the Iarlles Alsen quotes a prophecy of Glyndwr's defeat:

In storm and tempest was he born,

On crag and hill he roams forlorn;

He who was born to wear a crown,

Before a Saxon must bow down. (15)

Similarly, in Gladys of Harlech, the Dewines (a witch or prophetess) known as the Lady of Gêst prophesies the accession of Henry Tudor: "King of England reign will he- / He shall a Seventh Henry be" (2: 160). Spooner dovetails this 
with a prophecy that Gladys will be restored to her inheritance and Wales "emancipated from the thralldom which it now endures" (2: 159). Thus, she represents the accession of Henry VII (arguably a rebel and usurper) as the restoration of the rightful line.

Emma Robinson uses the prophecy in a particularly interesting way in Owen Tudor. The novel opens with Owen returning home to Penmynydd to find his father dying from an incurable wound sustained when he fought at Glendower's side during the Battle of Shrewsbury. His father gives him a silver egg, which contains Glendower's prophecy. It identifies Owen as "Arthur's blood, of Tudor line" and warns him:

Woo no daughter but a King's,

Sweetly though the Mermaid sings,

And sons of Kings thy sons shall be,

Kings of the waves and freer free. (25)

Owen and his father misinterpret this as a sign that Owen will lead a victorious rebellion against the English. Thus, Owen leaves Wales for France, "burn [ing] with a desire to remove the stigma of barbarism from his country and lineage" (33). The reader who knows her history will recognize the irony of the fact that his dynasty will be founded on his prowess not on the battlefield, but in the bedroom.

Owen Tudor is a particularly problematic figure as a national hero. Relatively little is known of him other than that he was the secret second husband of Catherine de Valois (daughter of the French king and the young widow of Henry V). Through their son Edmund Tudor, who married Margaret Beaufort, Owen Tudor was sire to the Tudor dynasty, which was established when his grandson, Henry Tudor (the only son of Edmund and Margaret), became Henry VII after the Battle of Bosworth. Owen Tudor's historical significance, therefore, is sexual and dynastic rather than martial -a role we more usually associate with women. One story has it that he attracted Catherine's attention by falling into her lap while dancing, another that he caught her eye while swimming. ${ }^{16}$ Neither story is particularly heroic, and Owen Tudor's princely Welsh lineage has tended to be ignored by English historians. Thomas Penn, for instance, dismisses him as "a charming, fast-talking Welsh chamber servant of Catherine's", and comments that Henry Tudor's royal blood was "irretrievably tainted". ${ }^{17}$

Robinson's handling of this story is fascinating in the way that she uses it to open a space in history for female heroism. While Owen looks the picture of a courageous knight, he loses almost every fight, and the text repeatedly presents him as an erotic object for the female gaze. He is first introduced in terms of his physical charms, like a male Aphrodite emerging from the sea. Casting off a long mantle and cap of wolfskin covered with sea spray after 
his voyage, he reveals "a figure and countenance [...] which would have riveted the admiration of a painter or sculptor" (7). Robinson comments:

Either might have taken it as a perfect model, in stature, proportions, and rich colouring, for the robust beauty of the hunter whom the Queen of Love loved; or perhaps, from the fiery, haughty, and impetuous character of the physiognomy, though still in the earliest and almost womanly bloom of youth, as an ideal of Achilles when he passed for a nymph among the daughters of the ocean. (7)

Despite the wolfskin cloak, this Adonis-Achilles is very much a feminized male beauty. What Robinson repeatedly calls the "beauty of his person" (169) attracts a succession of women. Later, he does, indeed, come to Catherine's notice by tumbling into her lap while dancing. In Robinson's version, this is a consequence of being made to dance in full armour by her father, the mad King Charles VI. The effect is still bathetic.

In this feminization of her national hero, Robinson was working in a tradition of earlier sentimental and Gothic heroes by women, including the portrayal of William Wallace in Jane Porter's national tale The Scottish Chiefs: A Romance (1810). ${ }^{18}$ In Porter's novel, Walter Scott allegedly complained, "the character of Wallace" had been "frittered away to that of a fine gentleman" ${ }^{19}$ suggesting both feminization and lack of historical authenticity. Scott himself was praised for remasculinizing the national fiction in what Carlyle called "this sickliest of recorded ages, when British Literature lay all puking and sprawling in Werterism, Bryonism and other Sentimentalism tearful or spasmodic". ${ }^{20}$ As Fiona Price has pointed out, however, Porter's Wallace represents an ideal of virtuous patriotism and self-sacrificing heroism, while Porter also uses two opposing female characters, Lady Mar and Lady Helen, to suggest that it is through sublimating their sexuality that women "are able to take on the quasi-masculine role of patriot". 21

Robinson's feminized Owen is also consciously placed in the tradition of unheroic protagonists which Scott's Waverley adapts from Cervantes' Don Quixote (1604-05, 1615). Famously, Scott's Waverley is a passive, unprepossessing figure, characterized by Lukács as "a more or less mediocre average Englishman". ${ }^{22}$ Like Waverley and Don Quixote, Owen is led astray by romantic dreams of chivalry, inspired by the tales of his supposed ancestor Arthur enhanced by Glendower's prophecy. Arriving in France, he is a Don Quixote figure, wearing mail of "antique workmanship" (34), accompanied by his rustic retainer, Rhys ap Goronwy, on a "little shaggy steed" (38), and attempting to prove his valour by single-handedly challenging Henry $\mathrm{V}$ as a usurper. Owen dubs himself "The Maiden of Chivalry" (38), a title which recalls Scott's description of himself as "like a maiden knight with a white shield, assum[ing] for my hero, WAVERLEY, an uncontaminated name". 23 
This is itself an allusion to Don Quixote, where the eponymous protagonist, having not been knighted, is obliged to wear "white arms". ${ }^{24}$

In Owen's encounter with Henry $\mathrm{V}$ and his army, Robinson depicts a clash of cultures where the Welshmen are seen as primitive and barbaric. Rhys's Welsh speech is derided as "goose-gabble" (42), while Henry laughingly comments, "A Welshman [...] I begin to smell roast cheese", and calls Owen "A King of goats and snows!" (54). In a symbolic encounter, a disguised Henry $\mathrm{V}$ beats Owen in single combat and, when he still refuses to surrender, knights him as the "Chevalier Sauvage", taking his egg of prophecy and telling him to "live to make ladies simper at banquets" (75). Travelling on to Paris, Owen then, like Waverley, finds himself caught in the middle of a conflict between two opposing sides (here, the civil war between the Burgundians, led by Duke John the Fearless, and the Armagnacs) and between two women (the dark "minstreless" Huéline de Troye [86] and the fair but shallow Princess Catherine). Thus, despite his warlike appearance, Robinson undermines Owen's potential as a Welsh national hero,

Making Owen an ineffectual if sexually attractive figure allows Robinson to open up a space in the novel to explore female national "heroinism" and desire in the figure of Huéline de Troye. ${ }^{25}$ In the interstices of recorded history, Robinson constructs a "private chronicle" (440) which centralizes women's influence-chapter 31 is even entitled "The Influence of Private on Public History" (362). A "bardess-a Druidess of the harp!" (83), Huéline is both the poetic inspiration of the Burgundian revolutionaries and a witch-like enchantress. Her name, Huéline (from the German, meaning "an intelligent woman") de Troye, recalls both Helen of Troy and Chrétien de Troyes, the twelfth-century poet of the Arthurian romances. She is called a "modern Héloise, the Sappho of our times!" (146) and compared to the French medieval poet Marie de France (83)-again known for using Arthurian material. The daughter of an imprisoned demagogue, Huéline first appears in the novel in male disguise as the "Poor Scholar", who delivers an impassioned oration against the Armagnacs. Such cross-dressing is a common motif in historical novels and connects her with other female figures such as Lady Mar and Lady Helen in Porter's The Scottish Chiefs. But Huéline's skill as a poetic orator also recalls Madame de Staël's hugely influential Corinne, or Italy (1807), written in defiance of Napoleon, where the Scottish Lord Nelvil is torn between the dark and brilliant Italian nationalist poet and improviser Corinne and the blonde, English Lucile. ${ }^{26}$

Like Corinne's improvisation at the Capitol, Huéline's oration speaks for a repressed nation. It is "an assault on feudalism itself" (116), which espouses, a few centuries too early, the values of the French Revolution. The narrator comments that the scholar's "discourse might have been styled an ancient 'Rights of Man"' (116), and adds: "Liberty, equality, fraternity! - words which have moved the earth-were not on the lips, but they were in the 
essence of the splendid dream which the young orator discoursed in glowing poetry to that strange, but fascinated audience!" (117). This conscious anachronism ensures that we read Robinson's account of the ensuing mob violence in Paris through the retrospective lens offered by our knowledge of the French Revolution. Moreover, Robinson's novel was published the year after the Paris revolutions of 1848, providing another level of resonance. When Owen, himself "a son of the conquered" (116), thrills to the scholar's oration, the parallel between the oppressed Parisians and the vanquished Welsh is clear.

"[A]t war with the dominant influences of the age" (178), Huéline is presented as an anachronism herself-a woman ahead of her time. She is the "Mermaid" or siren against whom the prophecy warned Owen. In a highly charged scene, again recalling one from Don Quixote, she unarms Owen in her bedchamber where he is to stay in hiding, removing his armour like "Venus disarming Mars" (169). Once they have consummated their love and Huéline has lost "the only permanently attractive [fascination] in woman-purity" (198), Owen, holding to the promise of the prophecy, refuses to marry her. Marrying Sir Pierre de Giac instead, she moves into court circles and becomes a political force. In contrast, Owen, like Scott's Waverley, wavers between sides and finally swears allegiance to Henry V. After Henry's marriage to Catherine, Robinson disposes of Owen's future role in a perfunctory paragraph: "Every reader of English history is aware that the royal Tudor dynasty [...] sprang from the union of an obscure Welsh gentleman with the widow of Henry V" (440). She ends the novel instead with an account of Huéline's remarriage, after the murder of Pierre de Giac, to the man who instigated his death. Ultimately, it is the heroic figure of Huéline, rather than Owen, who articulates and represents the cause of the conquered, whether French or Welsh.

In Gladys of Harlech, Spooner writes a different story of female national heroinism, which retains the specificity of the Welsh context. She does this, like Robinson, by displacing the male figures of recorded history-including Henry Tudor, who is presented as a "sallow foreigner" (3: 39), cold and untrustworthy-and centralizing a pair of female figures: Gladys, the "daughter of Harlech", who has been disinherited when her family are routed from their ancestral castle by the English, and the Dewines, the Lady of Gêst, who prophecies Henry Tudor's victory. Spooner splits the functions Robinson combines in Huéline, making Gladys an idealized and pure figure of female national heroinism, while the Dewines, a witch who can raise a storm at sea by tying a knot in her handkerchief, is a much darker figure. Like many women writers' historical novels from Sophia Lee's The Recess (1783) onwards, ${ }^{27}$ Spooner thus uses the Gothic to write women back into history.

The text is unambiguously partisan in its depiction of a subjected Wales, "bent under the Saxon yoke" (1: 1). Here, Spooner reworks the notion of 
the "Norman yoke" popularized by Scott in Ivanhoe (1819), where Wamba quotes a Saxon "proverb":

Norman saw on English oak,

On English neck a Norman yoke;

Norman spoon to English dish,

And England ruled as Normans wish;

Blithe world in England ne'er will be more,

Till England's rid of all the four. ${ }^{28}$

This invokes an idealized Anglo-Saxon England-what Scott calls "the milder and more free spirit of the Saxon constitution"-replaced through conquest by the "Norman yoke" of feudalism. ${ }^{29}$ Scott's solution is to unite these two warring races through the symbolic marriage of Ivanhoe and Rowena "as a type of the future peace and harmony betwixt two races, which, since that period have been so completely mingled, that the distinction has become utterly invisible". ${ }^{30}$ The "English" are the result of that blending of Norman and Saxon through intermarriage.

In contrast to this, Gladys symbolizes the disinheritance of Wales under a Saxon yoke. Like Robinson's Owen Tudor, she has grown up hating the Saxon invaders- “A Saxon! A Saxon! cruel Saxons! I hate the Saxons!” she cries as a child (1: 158) - and this is exacerbated when she is taken captive and kept in Harlech as a hostage. Her deep pleasure in the Welsh landscape (3: 124) reinforces the sense that she is (like de Staël's Corinne and Robinson's Huéline) the symbol or genius of her beleaguered nation. However, like Raine's Eleri, she also symbolizes the wider disinheritance of women within patriarchal culture and their erasure within historiography. She is associated within the text with other heroic female figures: Margaret of Anjou, "the heroic Queen" (1: 120) who had taken up arms on behalf of her son, Joan of Arc and "the brave Jeanne Hachette" (2: 93).

Gladys's intervention in history is civic rather than warlike. She petitions Henry as "blood of our blood" to free his fellow Welshmen from oppression once he is king: "I implore you to promise that when the day comes [...] you, in mercy, will issue a charter to emancipate our people from that painful Saxon yoke, a yoke loathsome to every noble, true-born Cambrian heart" (3: 54). Symbolically, she stitches a Red Dragon banner, which he carries at the Battle of Bosworth (3: 129). Once he is king, Gladys holds Henry to his promise. In addition to restoring her to Harlech, he gives her a charter, which emancipates her fellow countrymen: "Henceforth, England and Wales enjoy equal privileges. [...] Heart and soul let England and Cambria be united" (3: 312). Gladys's return home to Harlech on a milk-white charger is a triumphal progress, with "her people" hailing her as a deliverer: "happy Cambria, freed Cambria-Cambria for ever! The Saxon yoke was no more, for Cambrian and Saxon were one; the old privileges of the people being given back to them" (3: 315). 
Spooner, however, eschews the Scott-model marriage ending that this unity would seem to beg. Although Gladys's own mother was Saxon, Gladys sacrifices her love for the Saxon Ethelred in order to serve her people. The novel ends with Ethelred and Gladys as "keepers" of Harlech and Cricceath, respectively, and "equally guardians of the freedom, privileges of the noble spirits in Cambria" (3:320). While the subtitle of the novel, The Sacrifice, could be read as indicating another version of the female patriot's sublimation of sexuality (as in Porter's The Scottish Chiefs), it is equally possible to read Spooner's ending as a refusal of the submergence of the heroine in marriage and an assertion of her equality. Rather than "mingling", as in Ivanhoe, the image of the "two strong posts that protect the bay" (3: 320) suggests a balance between the two races and genders.

While Gladys is the titular heroine of this novel, it is the mysterious Dewines, the Lady of Gêst, who is the real force behind historical process. She is introduced as a "Weird Lady", nearly five feet eleven inches tall, with a "wild expression", "long straggling gray hairs", "parchment skin" and "spindle legs" (2: 26-27), who dances around two crossed sticks and curses in rhyming couplets which recall Shakespeare's witches in Macbeth: "I'll kill an infant, hearest thou that! / And rub thy brow with the innocent's fat" (2: 29). After prophesying Henry VII's accession, it is the Dewines who arranges for Gladys to make Henry promise that he will sign the charter emancipating the Welsh (2:159-60). She also haunts the future Richard III, appearing at key moments such as the Battle of Tewkesbury and the murder of Henry VI to curse him, and causing the words "fratricide, regicide, murderer of the innocent" (3: 216) to sound mysteriously through the galleries of Windsor. Her prophecies and interventions thus drive the plot.

Spooner is rewriting not just historiography here, but also canonical literature. In a scene which draws closely on Shakespeare's Richard III, the Dewines appears before the Battle of Bosworth to confront Richard, telling him: "Dickon, Dickon, thou art bought and sold" (3: 239). In Shakespeare's play, these words are written on a scroll found by the Duke of Norfolk and given to Richard: "Jockey of Norfolk, be not too bold, / For Dickon thy master is bought and sold". ${ }^{31}$ In Spooner's version, these warnings come from the Dewines, and it is Gladys's uncle, Kynfin Tudor, who strikes the fatal blow at Richard III, symbolically taking vengeance for Wales. Spooner goes on to displace Henry Tudor from the role of Welsh national hero. After Henry's accession, the Dewines tells Kynfin and Gladys not to trust the new king, whose loyalties have already shifted away from Wales-"His soul is narrow and avaricious. [...] He is a Judas" (3: 262-63) —and motivates Gladys to hold Henry to his promise. Spooner thus credits female heroinism-that of both Gladys and the Dewines-within this myth of Wales as an emancipated nation.

While Gaskell is equally concerned with Wales as a dispossessed nation, she plays out the drama of public and private betrayal within the microcosm 
of the Griffiths family. Her concern here is with the erasure of the maternal within national culture and history. "The Doom of the Griffiths" transposes the Oedipus myth to a Welsh setting. The Griffiths son of the ninth generation, Owen, knowing of Glendower's curse on his family, obsessively reads Sophocles' Oedipus Tyrannus (113). Owen's mother died when he was small and his father, Squire Griffiths, having doted on him as a boy, then marries a woman who alienates him from Owen and encourages him to favour her own son. This withdrawal of his father's love leaves Owen desperate for "someone to love him for ever" (120), so he secretly marries Nest, a girl from a lower social class, and they have a baby. When his father finds out, he confronts Owen and Nest and, in an "ungovernable rage" (124), he takes the baby from Owen, throws it to Nest and leaves the house. The baby hits the edge of the dresser and is killed. In a struggle on a cliff, Owen then inadvertently knocks his father into the sea and kills him.

Owen sees his father's death as the inevitable working out of the curse: "it was my doom" (134), he says. But Gaskell offers two possible interpretations - the supernatural (i.e. fate) or the psychological (the particular family dynamic combined with psychological obsession). On the one hand, this story seems to call out for a psychoanalytic reading as a working out of allegedly universal Oedipal structures. On the other hand, Gaskell uses the introductory comments to locate this story within the specific history of Glendower's rebellion and to state her sympathy for his cause. Psychoanalytic and historical interpretations of Gothic texts are usually seen as antithetical and irreconcilable. But here the mythic or psychoanalytic level of the story (the Oedipal-Gothic "curse"), which should be at odds with the factual or historical level, is used by Gaskell to suggest the way that repetitions of male violence recur through history, beginning with a betrayal which is both national and familial: Rhys ap Gryfydd's betrayal of his "more than brother" Glendower. Such betrayals lead to the fall of the "house of Bodowen", and thus the loss of Welsh lands to the "Saxon stranger". At both familial and national level, male violence and betrayal are to blame.

On a wider scale, Gaskell offers a critique of the Oedipal myth itself as we now understand it. Owen kills his father not because he desires his mother (the Freudian paradigm), but because his father has betrayed him-firstly, by withdrawing his love and, secondly, by killing Owen's son, his own grandson. Gaskell makes it clear that men can provide maternal nurturing, as Squire Griffiths does when Owen is a child, and that when they fail to do so, the consequences are damaging. The fact that Nest is also motherless suggests the wider erasure of the maternal within patriarchal culture. The baby's death symbolizes the damage done by this absence of mothering. It also suggests that the originary transgression in the Oedipal myth is not Oedipus's marriage to his mother, but Laius's action in separating his baby son Oedipus from Jocasta and exposing him to die with his feet pierced and tied together. The 
patriarchal inheritance here is the historical "curse" of male violence, which denies the maternal and disinherits the children at both the familial and the national level.

Like Gaskell and Spooner, Allen Raine uses Gothic tropes to explore and gender the themes of disinheritance and betrayal. She uses the classic female Gothic plot (as popularized by Ann Radcliffe) of a disinherited heroine, Eleri of Garth, imprisoned in a threatening Gothic castle, Twr-yGraig, at the mercy of her wicked uncle, Gwythern. In another typical Gothic trope, Eleri is doubled by her cousin Indeg, who bears an uncanny resemblance to her. Indeg's features are more symmetrical that Eleri's, but "through those blue eyes no soul looked out" (38), and she amuses herself by wringing the necks of helpless sparrows. Gwythern's plan, as in Wilkie Collins' The Woman in White (1860), is to substitute Indeg for Eleri, locking Eleri in a convent so that Indeg can claim her inheritance. Raine repeatedly draws our attention to the difference between then and now: "Those were the days of cruelty, when scarce a tender thought was extended to the poor and unfortunate of human kind, much less to the animal world" (38). The Gothic trappings draw attention to the otherness of the past, but also encourage us to read the text in symbolic terms as an allegorical comment on the present.

The past is a world where women are at very real risk of violence. On their arrival at the castle, Eleri's talkative maid, Gwenna, recounts a warning story she has just been told about Culdeth, the brutal porter:

We must guard our tongues well [...] or we may lose them. Once upon a time, Branwen, the daughter of Gwain, came here when her father had been killed in a fight and her tongue wagged like mine, and Culdeth cut it off, or a great piece of it, and silenced her for ever. (43)

The story recalls Philomela and the age-old prohibition on women's speech. But it also has a prophetic force for Gwenna, who, having discovered some of the secrets of the Twr, is murdered by Culdeth when she tries to escape. Eleri herself is threatened with immurement in the convent of St Ann in Bardsey, where she fears that she will be imprisoned in "some narrow cell, or worse: perhaps within some deep-set wall that grows up stone by stone around her" (99). When Indeg, caught in the snare she has set for Eleri, is carried off to Bardsey instead, Eleri reiterates the story: "Tis said the Abbess is cruel and hard $[\ldots]$ and hath ere now buried a nun alive, building up stone by stone the wall, that was her tomb" (189). The motif of live burial is another classic female Gothic trope, deployed by writers such as Gaskell to figure women's erasure and disinheritance within patriarchy. This violent suppression of women undermines the romantic notions of the chivalric past enshrined in the "endless pattern of knights and dames who rode to battle or the chase" (83) which Eleri wearily works into her tapestry. 
Interwoven with the plot of the disinherited Gothic heroine is the Gothic plot of the disinherited and suppressed Welsh nation. The refrain which runs through the text- "Those were the days"-draws attention to the rich specificity of the Welsh culture which has been erased by conquest: "In those days the Welsh were famed for the dancing", we are told, and "Those were the days of boisterous and vigorous dancing" (56). As in Gaskell's story, the heart of this plot is the betrayal of Glyndwr-and, by extension, the nation-by those who should have supported him. When the news of Glyndwr's defeat is broken, it is a measure of their moral turpitude that Gwythern and Indeg drink to "the rulers of the land, whoever they are!", whereas Eleri patriotically asserts: "I would Glyndwr had conquered" (51).

The theme of betrayal is figured in the uncanny form of the sin-eater, who is first called upon when Gwenna dies unshriven to take her sins upon himself by eating the food laid out over her body. ${ }^{32}$ Raine presents this as a custom which marks historical difference: “The scapegoat' was in continual request at a time when human life was held so lightly as it was in that turbulent period" (82). But she also notes that it was "a creed that lived on in Wales for many centuries" (82), the last one being still in evidence in 1825, as her endnote indicates (192). This makes the custom much more specific to Wales and implies that conquest has erased the rich culture of music and dance, leaving the defeated Welsh with only their superstitious beliefs. In keeping with the female Gothic tradition of the explained supernatural, the sin-eater is actually a forward-thinking Lollard who only pretends to eat the "tainted" food given to him: "not for the sin that dwells in it", he tells Eleri, "for that I believe not-but because it might bring death and disease" (110). Furthermore, he is revealed to be Iestyn Mai, the lost son of Eleri's aunt. Iestyn has taken on the role of sin-eater in penance for unwittingly taking part of the gold that was the price paid to his friend, Seithyn Owen, for betraying the hiding place of Glyndwr. Iestyn's "sin" actually lies in a lack of proper patriotic feeling. As he explains to his former friend, Deraint: "I could not feel as thou didst too about our land of Cymri, but [...] I argued it were better she should cease her struggles and give her hand to the Saxon King" (151).

The message of Hearts of Wales, Jane Aaron suggests, is that "the national disgrace of not having been stalwart enough in the support of independence movements is at the heart of Wales", which was particularly relevant at the time of this novel's publication, after the failure of the 1890s Welsh Home Rule movement. ${ }^{33}$ However, the gendered metaphor of forced marriage used by Iestyn-"Cymri [should] cease her struggles and give her hand to the Saxon King"-draws attention to the particularly complex position of women in relation to this struggle. It foregrounds the parallel between Wales as a conquered nation and Eleri as a subjugated and disinherited woman. This is a metaphor which runs through all the texts I have been 
discussing here. Denied their inheritance and an identity within the polity, these texts ask: How can women contribute to the forging of national identity? In the face of national defeat, how can they demonstrate a redemptive hero (in)ism?

Each of these texts offers a different answer to these questions. Despite the failure of Glyndwr's rebellion, Raine engineers a happy ending for the individual characters in her "old romance": Iestyn Mai redeems himself by sacrificing himself in Deraint's place (a substitution reminiscent of Sidney Carton's similar action in Dickens's A Tale of Two Cities [1859]), thus allowing Deraint and Eleri to be united in love. The mode of romance allows Raine to restore the heroine to her rightful inheritance but, in the aftermath of the 1890 s, a similar restitution for her country does not seem possible. Eleri, like Gladys, is a somewhat passive figure: "Eleri was no heroine", Raine tells us (61). Both characters' heroinism lies more in their importance as a symbol of national womanhood. Spooner's ending could be criticized as a fantasy of female heroinism, as well as national emancipation, which glides over the ambiguities inherent in the notion that "Cambrian and Saxon were one". This idealization of the female national heroine was perhaps inevitable as a response to the excoriation of Welsh womanhood in the Blue Books. In contrast, the Dewines and Huéline are active agents of history. This, however, places them outside the boundaries of appropriate behaviour for a nineteenth-century woman, and both are stigmatized as witches. It is notable that Robinson subversively allows Huéline a happy ending as "the wittiest, liveliest, and most intriguing lady of the court of Charles VII!" (440). Of all four writers, it is perhaps Gaskell who goes furthest in analysing the connections between nation and patriarchy. Her skilful intertwining of psychological realism with a mythic and symbolic level reworks the Oedipal story to show the repercussions of male violence as a betrayal on both a personal and a public level. While these texts offer important interventions in the shaping of national history, there is a sad irony in the fact that it is the defeat of the nation which allows a space for these women writers to imagine a female heroinism.

\section{Notes}

1. Allen Raine, Hearts of Wales: An Old Romance (1905); rpt. in Hearts of Wales, Garthowen, Torn Sails (London: Hutchinson, n.d.), p. 9. Subsequent references are cited parenthetically and are to this edition.

2. Emma Robinson, Owen Tudor: An Historical Romance (1849; London: George Routledge, n.d.); L. M. S. [Louisa Matilda Spooner], Gladys of Harlech; or, The Sacrifice. A Romance of Welsh History, 3 vols. (London: Charles J. Skeet, 1858); Elizabeth Gaskell, “The Doom of the Griffiths” (1858), Gothic Tales, ed. Laura Kranzler (London: Penguin, 2000), pp. 103-38. Subsequent references are cited parenthetically and are to these editions. 
3. Georg Lukács, The Historical Novel, trans. Hannah and Stanley Mitchell (1937; Lincoln: U of Nebraska P, 1962).

4. Avrom Fleishman, The English Historical Novel (Baltimore: Johns Hopkins UP, 1971); Jerome de Groot, The Historical Novel (London: Routledge, 2010).

5. Richard Maxwell, The Historical Novel in Europe, 1650-1950 (Cambridge: Cambridge UP, 2009), pp. 113-230; Anne H. Stevens, British Historical Fiction before Scott (Basingstoke: Palgrave, 2010).

6. Katie Trumpener, Bardic Nationalism: The Romantic Novel and the British Empire (Princeton, NJ: Princeton UP, 1997).

7. Jane Aaron, Nineteenth-Century Women's Writing in Wales: Nation, Gender and Identity (Cardiff: U of Wales P, 2007), p. 11.

8. See Aaron, Women's Writing, pp. 114-17 and Jane Aaron, Welsh Gothic (Cardiff: U of Wales P, 2013).

9. John Henry Raleigh, "What Scott Meant to the Victorians" (1963), Critical Essays on Sir Walter Scott: The Waverley Novels, ed. Harry E. Shaw (New York: G. K. Hall, 1996), pp. 47-69 (49).

10. Marion Shaw, "Sylvia's Lovers and Other Historical Fiction", The Cambridge Companion to Elizabeth Gaskell, ed. Jill Matus (Cambridge: Cambridge UP, 2007), pp. 75-89 (77).

11. Sally Jones, Allen Raine (Cardiff: U of Wales P, 1979), p. 9.

12. See Gwyneth Tyson Roberts, The Language of the Blue Books: The Perfect Instrument of Empire (Cardiff: $U$ of Wales P, 1998) and her essay on Jane Williams (Ysgafell) in this journal.

13. In order to foreground this issue of nationality, I have used the spelling deployed by each author in quotations from and in analysis of their book but retained the widely accepted Welsh spelling Owain Glyndwr in discussion of the historical figure.

14. William Shakespeare, I Henry IV (1598), 3.1.13-14.

15. Aaron, Welsh Gothic, p. 59.

16. R. A. Griffiths, "Tudor, Owen [Owain ap Maredudd ap Tudur] (c.1400-1461)", Oxford Dictionary of National Biography, Jan. 2008, Oxford UP, 5 Jan. 2015 $<$ http://www.oxforddnb.com/view/article/27797>.

17. Thomas Penn, The Winter King: The Dawn of Tudor England (London: Penguin, 2012), p. 3.

18. Jane Porter, The Scottish Chiefs: A Romance, ed. Fiona Price (1810; Plymouth: Broadview, 2007).

19. Fiona Price, introduction, Porter, pp. 9-33 (15).

20. Thomas Carlyle, "On Sir Walter Scott" (1838), The Complete Works of Thomas Carlyle, Volumes 1 and II (New York: Thomas Y. Crowell, 1869), pp. 400-60 (416).

21. Price, pp. 18, 19, 25.

22. Lukács, p. 33.

23. Walter Scott, Waverley; or, 'Tis Sixty Years Since, ed. Claire Lamont (1814; Oxford: Oxford UP, 1998), p. 3.

24. Miguel de Cervantes Saavedra, Don Quixote, trans. John Rutherford (1604-05, 1615; London: Penguin, 2000), p. 36.

25. I have borrowed the term "heroinism" from Ellen Moers' important discussion of Corinne in Literary Women (London: Women's P, 1978), ch. 9.

26. Madame de Staël, Corinne, or Italy, trans. Sylvia Raphael (1807; Oxford: Oxford UP, 1998). 
27. Lee's The Recess tells the story of the imaginary twin daughters of Mary, Queen of Scots. See April Allison's useful introduction to Sophia Lee, The Recess: or, A Tale of Other Times (1783; Lexington: UP of Kentucky, 2000), pp. ix-xliv.

28. Walter Scott, Ivanhoe, ed. Graham Tulloch (1819; London: Penguin, 2000), p. 225.

29. Scott, Ivanhoe, p. 16.

30. Scott, Ivanhoe, p. 398.

31. William Shakespeare, Richard III, 5.3.305-06. The Complete Works of Shakespeare, ed. W. J. Craig (London: Oxford UP, 1935), p. 730.

32. For an exploration of the figure of the sin-eater in Welsh writing, see Aaron, Welsh Gothic, pp. 170-200.

33. Aaron, Welsh Gothic, p. 182.

\section{Disclosure statement}

No potential conflict of interest was reported by the author. 


\title{
๑ OPEN ACCESS
}

\section{WELSH WOMEN'S INDUSTRIAL FICTION 1880-1910}

\author{
Kirsti Bohata and Alexandra Jones
}

\begin{abstract}
From the beginning of the genre, women writers have made a major contribution to the development of industrial writing. Although prevented from gaining first-hand experience of the coalface, Welsh women writers were amongst the first to try to fictionalize those heavy industries-coal and metal in the south, and slate in the north-which dominated the lives of the majority of the late nineteenth-century Welsh population. Treatment of industrial matter is generally fragmentary in this early women's writing; industrial imagery and metaphor may be used in novels that are not primarily "about" industry at all. Yet from c. 1880-1910, Welsh women writers made a significant-and hitherto critically neglected-attempt to make sense in literature of contemporary industrial Wales in powerful and innovative ways. This essay maps their contribution and considers anglophone Welsh women writers' adaptations and innovations of form (particularly romance) as they try to find a way of representing industrial landscapes, communities and the daily realities of industrial labour. It identifies the genesis in women's writing of tropes that would become central to later industrial fiction, including depictions of industrial accident, injury, death and disability. And it explores the representation of social relations (class, gender, ethnicity, sexuality) and conflict on this tumultuous, dangerous new stage.
\end{abstract}

Women writers have been central to the development of the industrial novel, as with Elizabeth Gaskell's Mary Barton (1848) and North and South (1855), and George Eliot's Felix Holt (1866). But the heavy industry that dominated in Wales - coal, iron, steel and quarrying-is notable for its absence in the early canonical novels by women (and men). ${ }^{1}$ These industries were arguably less accessible to women writers with the necessary education and leisure to write than the factories which formed the basis of much of the early industrial fiction. There is a corresponding neglect in critical studies: in Susan Zlotnick's Women, Writing and the Industrial Revolution, mining is mentioned just once, in passing relation to Felix Holt, and there is a similar dearth in relation to women writers in earlier studies by Martha Vicinus and Catherine

This is an Open Access article distributed under the terms of the Creative Commons Attribution License (http:// creativecommons.org/licenses/by/4.0/), which permits unrestricted use, distribution, and reproduction in any medium, provided the original work is properly cited. 
Gallagher. ${ }^{2}$ There are some important early literary exceptions. Fanny Mayne's Jane Rutherford; or, The Miners' Strike (1853-54) is set in the 1840s and highlights the reforms of the 1842 Coal Mines Act. ${ }^{3}$ The American novella Life in the Iron Mills (1861), by Rebecca Harding Davis, is another example of a fictional engagement with heavy industry, although its innovative dreamlike style did not set the pattern for later novels. Frances Hodgson Burnett included some colliery scenes in That Lass o' Lowrie's (1878), which was written partly in Lancashire dialect. In Wales, women writers began to incorporate industrial topography and workers into their fiction from around $1880 .{ }^{4}$ Frequently, the industrial content was a backdrop, an acknowledgement of the industrial features of the landscape in which the characters move, or the adoption of (sometimes detailed) industrial metaphors. In several novels, however, this landscape becomes an important plot device in its own right. When we do find whole novels, or significant sections of a novel, concerned with representing life in the coalfields or quarries, the genre is romance. While this genre eventually closes down industrial conflict in unsatisfactory (implausible) ways, it is capacious enough to provide some vivid scenes below ground and to represent strikes. As feminist critics have argued, reading beyond the formal boundaries of the genre allows us to recognize the social tensions and exposure of ideologies which are present in romance and melodrama. ${ }^{5}$ The contradictions and dilemmas alluded to in these novels include class, gender, and national and linguistic survivalthemes centrally relevant to the industrial south, even if they have been overlooked or marginalized in studies of later anglophone industrial writing. In the hands of Irene Saunderson, romance stretches to "presenting the harsh world of the miners and their resistance to the power of the mine owners in a language, clearly, aggressively, in the voice of the oppressed" ${ }^{6}$

The industrial fictions discussed here are certainly not working-class literature depicting “a working man's consciousness, his consciousness as a working man", which Raymond Williams made central to his narrowly gendered description of the "Welsh industrial novel". 7 The temptation is to write "not yet", since in surveys of industrial writing, the romances and awkward generic hybrids which use middle-class characters as a conduit for workingclass experience published prior to the First World War tend to be presented as a prehistory, a tortuous groping towards (and inevitably measured against) an authentic working-class realism. As Stephen Knight claims: "These first industrial Welsh fictions cannot position themselves for a full, sympathetic and consistent ethnographic account of the new world of industry in Wales as later writers from South-East Wales were to do". ${ }^{8}$

Undoubtedly, the generic conventions of romance ultimately draw the narrative away from overt industrial issues, and some ideological elements of the novels may be unpalatable to a modern audience, although the writing itself is not without merit. But our central claim is that this body of fiction, in which 
middle-class female novelists begin to make sense of their industrial regionsand to map the continuities between rural and industrial Wales-warrants a consideration on its own terms. Rather than reading these novels as lacking (in working-class authenticity) or as an immature phase in the development of an appropriate form (when melodrama and romance are abandoned in favour of realism), we try to consider the recurring concerns across the fiction in a more nuanced way. Thus, we focus on the common motifs and generic conventions of those novels by women writers which take their settings, or incorporate scenes and imagery, from industrial life. These include strikes and class conflict, injury and disaster, disability and caring, as well as recurring tropes such as hymn-singing and Christian faith, and conflict between English and Welsh. Many of these are themes which are taken up in later proletarian novels with which we are more familiar.

Many of the novels are out of print and the authors little known, so a short introduction is appropriate here. The five principal writers discussed are almost all from the upper or middle classes. In terms of wealth and social status, Amy Dillwyn (1845-1935) was probably the most privileged. Her father was a prominent Liberal Member of Parliament who owned a zinc works and had other industrial interests in the Swansea area, and metal extraction appears in her fiction. ${ }^{9}$ Dillwyn's novels, most of which were published in a short burst from 1880-87, focus on unconventional, adventurous young women, but her sympathy for working-class grievances is manifest in several scenes in different novels in which local workers turn on their "superiors". While the industrial element in her fiction is rarely centre stage, she uses realistic scenes of industrial accidents and injury as plot devices. The less wealthy Anne Beale (1816-1900) lived and worked as a governess in Llandeilo, close to the edge of the anthracite coalfield which extended into Carmarthenshire. Her didactic novel The Queen o' the May $(1880-81)$ was published by the Religious Tract Society in their Girl's Own Bookshelf imprint. ${ }^{10}$ Set on the western edge of the coalfields where farmers and colliers live side by side, her novel includes a dramatic pit explosion seen from the women's perspective. Mallt Williams (1867-1950), who with her sister, Gwenffreda, wrote under the pseudonym "The Dau Wynne", was born into an affluent family near the industrial centre of Swansea, but their novel A Maid of Cymru: A Patriotic Romance (1901) is set in Powys among the limestone quarries which supplied the ironworks to the south. Williams was active in the Young Wales and Pan-Celtic movements, and the novel reflects these concerns. Allen Raine (the pseudonym of Anne Adaliza Puddicome, 1836-1908) was the best known of all these writers in her own time. Late in life, she became a bestselling author. Her novels are set in her native west Wales, and she had little direct experience of industrial regions, but $A$ Welsh Singer (1897) and, more importantly, A Welsh Witch: A Romance of Rough Places (1902) include scenes set in the industrial south. 
Irene Saunderson (dates unknown) was the only author who wrote an entire novel set in the coalfields: A Welsh Heroine: A Romance of Colliery Life (1910). ${ }^{11}$ Little is known about her life, and that little is mainly gleaned from the preface to her novel in which she set down her qualifications for writing about life in the coalfield. As the wife of a doctor, she had lived in colliery communities for a number of years, and so was the closest of all the writers to her subjects. She was also a Welsh speaker, ${ }^{12}$ which may have given her further access to the communities in which she lived; certainly her novel includes more than the usual smattering of Welsh words. Saunderson, who mentions the late Allen Raine in her preface, was consciously writing in a Welsh female tradition, although in plot and elements of style $A$ Welsh Heroine bears more than a passing resemblance to Joseph Keating's Son of Judith (1900), a romance by a miner turned journalist. A sixth novelist, mentioned here only briefly, is Mabel Holland Grave (1861-?), who published a utopian novel Fraternity: A Romance (1888), which is part set in the north Wales slate quarries. Echoing Dillwyn's call for a rapprochement between the classes in The Rebecca Rioter (1880), Grave's imagined cross-class fraternity is to be nurtured by an explicitly Welsh literature and culture.

With the exception of Saunderson's A Welsh Heroine, the industrial experience, imagined from without, remains somewhat marginal in the novels discussed here, either textually (the industrial elements take up a few chapters or odd scenes) or spatially (the action often takes place on the edges of the coalfield-although arguably this border zone is itself a significant location). Yet, taken as a whole, Welsh women's industrial fiction is a substantial and pioneering attempt to "novelise" ${ }^{13}$ the turbulent life which had grown up with such dramatic speed around the heavy industries in Wales-spheres of life which were otherwise accessible only through journalism or government reports: "Journals contain frequent accounts of coal-mine accidents", writes Anne Beale in the course of dramatizing one such, "but outsiders do not realise what they are" ${ }^{14}$ And there are attempts to represent working-class life, most often from a female perspective: the struggle to care for relatives, to feed a family during a strike, and the agonizing wait for news from the pit.

What we find in these novels is a commentary on industrial relations from a particular bourgeois perspective. Strikes are viewed with regret if not outright hostility, yet the lot of the workers is portrayed as hard and always dangerous. Class conflict is not always a matter of misguided workers against paternalistic owners, as scenes in which soldiers aim their weapons at an unarmed crowd, or a gang of poachers shoot at a landowner suggest, and there is considerable sympathy amongst some writers for the discontents of the workers. The keynote of these novels, however, is rapprochement and fraternity, often framed in a specifically Welsh national context. Mabel Holland Grave gives the most detailed expression in Fraternity: A Romance. Part of the novel is concerned with "violent" and "ignorant" quarry 
workers in north Wales. ${ }^{15}$ Jane Aaron ably explores the novel's ideological allegiances to "young Wales" and "fraternal Socialism", in which the "classes $[\ldots]$ join the masses", ${ }^{16}$ but for all its "heady vision" of class unity, ${ }^{17}$ one cannot help sympathizing with the "bitter-faced" quarryman who equates the appeal to abandon class enmity with surrender: "It would be very convenient for the gentlefolks if we were all so high-minded". ${ }^{18}$

In his discussion of "The Strike Novel in the 1890s", H. Gustav Klaus suggests that there was an "unwillingness of the major practitioners of the novel to engage with industrial conflict at all. Class collision was, if at all, located elsewhere". ${ }^{19}$ In the case of Welsh women's writing, rural conditions and concerns are often more important than industrial relations, or rather the relationship between mine owner and colliers, manager and men, seems based on the paternalistic models of upper-class landowner and rural tenants. The working class often appear to be more peasant than proletarian. To some degree this overlap reflects the realities of an economy which included agricultural alongside industrial labour for many individuals, sometimes on a seasonal basis. Moreover, the location of mines and quarries in otherwise rural areas meant that, in life and fiction, moors, mountains and other semi-wild spaces were important presences.

Reflecting the overlay of industrial life on older rural class tensions, poaching is frequently represented as a prelude to or substitute for industrial conflict. While poaching may seem a petty offence and lacking in the kind of organized resistance associated with working-class protest, it is, in fact, closely linked in fiction and history with other, more organized, campaigns. In Chloe Arguelle (1881), Amy Dillwyn depicts mass poaching raids in which local working men turn skilled night-time hunters, defying landowners, magistrates, the police and even the local Member of Parliament. The novel describes "thirty or forty men, with their faces blackened, spearing salmon by torchlight quite openly. No one attempted to interfere with them and most of the inhabitants of the place quietly watched [...] from the bridge" ${ }^{20}$ In one incident, the poachers open fire on policemen and the Member of Parliament. Although Dillwyn does not use the term "Rebecca", she is clearly drawing on the salmon-poaching raids which were at their height in the 1870s-described in contemporary newspaper reports as "the revival and reappearance of the terrifying Rebecca and her daughters". ${ }^{21}$ The gangs adopted many of the same elements of the earlier tollgate protests: organization, intimidation, disguise and ritual. Historically, these poaching "riots" were focused on the upper Wye, rather than more industrialized regions, but the point here is that poaching could become a recognized and effective form of organized protest.

The simmering threat of violence between workers and their overlords is played out in another poaching scene (which, in turn, provokes a strike) in A Maid of Cymru. The (English) quarry manager Garry Thoyts catches two 
of his workers with nets, ferrets and a sackful of rabbits. Acting on behalf of his cousin, the landowner and quarry owner, he confronts them. They refuse to give up their "pay" for their night's work, and a violent fight and chase ensue in which all three are hurt. ${ }^{22}$ Thoyts-with the aid of a passing gentleman-is ultimately victorious. The men are handed over to the law, spend six weeks in gaol for the poaching and lose their jobs, since Garry Thoyts, though no bigot, "had a country gentleman's instinct about poaching. It was the unpardonable sin in his eyes" (177). The dispute spills over into the quarry, and the inherent class tensions are brought into sharp relief. Since Thoyts will not "condone poaching" by reinstating the men, "[t]he quarry was stopped. War was declared between manager and men" (178).

The motives behind the strike are based on family loyalty and the workers' belligerence: the poachers have "numerous relatives working at Glascwm" and the men are "only too ready, on the slightest provocation, to break out into open insubordination" (177). Yet the willingness of the poachers' "fellow-workers" to "leave the quarry to a man" (177) is also a show of community solidarity -one which the unsavoury English agent who manages the wider estate hopes to exploit. Determined to rid the valley of as many of the "native" Welsh as possible, the agent plans to bring in blacklegs from England, not so much to break the strike as to displace the Welsh from their workplace and homes. As one orator puts it to the men, who have assembled on the martially named mountainside Carnedd y Milwyr ("Cairn of the Soldiers"):

[ ... ] this strike of Glascwm quarrymen is no small and simple matter-a mere dispute and difference between officials and men, which ye can settle or refuse to settle as ye choose. It is an affair that will be far-reaching in its consequences, for it affects our Motherland herself. (182)

Leaving aside the point that industrial action is likely to be considered more than "a mere dispute and difference" by those engaged in the material sacrifice and struggles it entails, the strike is central to the main theme of the novel: national survival. The strikers are treated to a lengthy speech by a local bard, in which the Welsh are constructed in racial and linguistic terms, and the men are reminded that they face the danger of "a colony of $[\ldots]$ strange men of Somerset settle[d] in your homes", since it is the "boasted ambition" of the English agent

[... ] to depopulate the Three Valleys of the "true red blood" and people them with aliens. [ ... ] Make him laugh on the other side of his face by refusing to fall into the trap he has laid for you [ ... ] and going back to your work in the quarries to-morrow, like loyal sons of Cymru. For Cymru is little and poor and weak, and she cannot lose her strong true-blood sons [ ... ] Ye have a heritage to guard, and as you be true men, see that ye guard it well. (183-84)

For their part, the poachers, in this national twist to the strike, will be "proud to sacrifice themselves for the good of their country" (184), compensated by 
"y Foneddiges" (184) - the gentlewoman and Welsh patriot of the title. Interestingly, the threatened anglicization or colonization of this corner of Wales extends beyond the immediate area of Dyffryn Crawnant and includes the "Three Valleys" of "Rhymney, Dowlais, and Tredegar", thus casting the "great industrial centres" (31) as actual or potential colonial outposts and, of course, recording the enormous demographic shifts underway in the region. $^{23}$

The six-month strike central to Saunderson's A Welsh Heroine is rather more firmly rooted in the economic concerns of the working-class community it depicts. The basis for the strike is a demand for "a five per cent. rise", although we are given no further context against which to measure the claim. ${ }^{24}$ The workers undoubtedly suffer from the strike: "To villages like Cwmglo, where the majority of the inhabitants depended entirely upon the wages earned in the pits, the gloom was indescribable, a gloom which deepened into utter darkness after a month or two had elapsed" (81). In contrast, the owners are conspicuous by their absence (their home is used by the officers of the cavalry brought in to prevent rioting). Although the aim may be to present both sides, the language associated with masters and men is telling: the masters are "firm" while the colliers are "obstinate" and about to become "idle", "preferring to plunge their families into the direst want than compromise" (81). The colliers are objects of pity rather than individuals with agency, with the exception of the heroine. During one "mob" scene, the military corners the crowd with near fatal consequences. Unable to disperse because the soldiers are in the way, the crowd listens in fear and confusion as the Riot Act is read and the soldiers take aim. The "mob" is not simply a band of angry colliers, but includes women and children, and thus the whole of the village is held at gunpoint. The narrative focuses on "the women's shrieks, and the shrill screams of frightened, half-suffocated children [that] filled the air with melancholy" (159). And as the soldiers "raise their carbines" and take aim, the commanding officer (and romantic hero) is prepared for "wholesale slaughter" of "his fellowcreatures who, in their helplessness, were utterly incapable of self-defence or retreat" (162). Melodrama provides a vehicle for Saunderson to expose the lethal class relations that would shortly culminate in the army being deployed in Tonypandy and Llanelli in 1910 and 1911, and, in at least one instance, opening fire. If the crowd is portrayed patronizingly as "poor, deluded creatures" (162), the soldiers' readiness to deliver "a hail of bullets $[\ldots]$ riddling them with their molten fire" (163) is damning. Although the officer is not explicitly condemned for his cold-blooded adherence to duty, the dramatic language speaks for itself: "One more word [ ... ] and the holocaust of blood and destruction would have commenced" (163). At the height of this crisis, the crowd is saved by the quick thinking and leadership of the working-class heroine, Morfydd Llewelyn. The strike 
ultimately ends with a compromise on both sides, yet the agency of the owners rather than the colliers is recognized: "conciliatory measures" are "offered and accepted by masters and men respectively" (266). And, by this time, the strike has been overtaken by the unfolding romance plot, which enacts a rapprochement between the classes.

According to H. Gustav Klaus, during the 1890s an "idealised portrait of the working-class leader" became a feature of "the altered approach of middle-class novelists $[\ldots]$ to the theme of industrial conflict. Once a ruthless demagogue or imposter, he now appears as the embodiment of integrity and self-abnegation" ${ }^{25}$ Male working-class leaders are conspicuous by their absence in these texts. There is the shadowy Twm in The Queen o' the May, one of the early agitators who is conveniently killed, along with his sympathizers, in a mine accident. In A Maid of Cymru, the foreman tries to keep the peace and persuade the English manager to respect local practices, but his task is really to mediate in the interests of keeping the quarry functional. Instead, the role of leader is performed by dynamic women with imagination and energy. Morfydd Llewelyn and Tangwystyl Hughes in A Welsh Heroine and A Maid of Cymru are two very different women, separated by social status and motives. But these determined women use similar techniques to provide direction and leadership to crowds of colliers or quarrymen: the power of Welsh hymns.

If this seems a stereotype too far, we need to recall the social milieu from which these novels emerge. In his book on Nonconformist literature, M. Wynn Thomas describes the "visceral splendour"26 of the Welsh hymns which formed such an important part of cultural and religious life:

The great hymns and hymn tunes have an incomparable personal and communal power. [...T]hey [...] empowered voiceless individuals and bonded people, sucked in from all parts by the vector of industrialization, together into coherent, structured, and orderly communities. These weren't the work of the professional classes. Hymns and melodies were largely the product of shepherds, tinplate workers, blacksmiths, miners and shopkeepers. ${ }^{27}$

In A Maid of Cymru, Tangwystyl gathers the strikers on a mountainside, intent on rousing their nationalism above more petty grievances. After the oration given at her request by the Eisteddfodic bard, she sings "songs of the Great Past-and of the Future Hope-the hymns they had first heard as lullabies from mothers' lips, and those more solemn strains that would be sung over them when their ears were sealed in the great silence" (185), until the men agree to return to work with a cry of "Cymru dros byth!" $(185),{ }^{28}$ thus averting the possibility of being driven out of the valley and replaced by English workers. In Saunderson's A Welsh Heroine, the personal and communal strength to be drawn from hymns is dramatized when Morfydd saves the panic-stricken crowd in "a gesture of inspired leadership" 
by singing "Mamgu's favourite hymn" and walking "slowly forward to meet the terrible, levelled carbines" (164). The crowd joins in, "obedient as little children", until "the hymn broke out with all the fervor of the Celtic "Hwyl" (164) and the crowd marches away, past the armed soldiersindeed, the soldiers mistake the Welsh hymn for a military "march" (173). For all its melodrama, this scene and the wider religious dimensions of the plot $^{29}$ place Irene Saunderson's industrial romance within that body of anglophone writing identified by M. Wynn Thomas as "the first distinctive AngloWelsh [literary] 'formation' - concerned to construct and develop 'the Nonconformist nation' by discursive means". ${ }^{30}$

The historian Philip Jenkins reinforces the importance in Wales "of the hymn as [an] expression of communal solidarity", arguing that "the love of choral music" engendered by evangelical Nonconformity would become "a vital distinguishing feature of Welsh life, and by no means only for nonconformists" ${ }^{31}$ Indeed, the centrality of hymns, which are identified by name or quoted at length (in translation), seems peculiar to Welsh industrial writing. Certainly the power of hymns and the act of singing are recurring motifs in women's industrial fiction. In addition to the examples above, in Allen Raine's A Welsh Witch, miners trapped underground use hymns to sustain them as they face starvation and madness: "as his trembling voice grew stronger $[\ldots]$ some inward calm awoke within him, some strong faith, some hope revived, and with clear and sonorous voice, he sang". ${ }^{32}$ In some instances, however, the special passion the Welsh are supposed to hold for music can be taken to ridiculous extremes, as in Anne Beale's The Queen o' the May. Much of the plot revolves around the passion for music shared by working folk and gentry alike. In this spirit, the mine manager goes down into the pit to try and counter the growing unrest amongst the miners: "I told them that the master was going to give them musical instruments and a trained instructor in the mines". He is rebuffed: "Tis more money, not more music we want", protest some of the men, who refuse to listen to his offer. Almost at once there is an explosion, which the manager and those interested in the musical instruments survive, while the malcontents who have moved to a different part of the mine are all killed. If the moral message was not plain enough, the heroine asks: "Then it was those who were true to their duty that were saved?"33

Thus far, the focus has been on the ways in which industrial scenes and settings have been used in conjunction with other narratives-the nationalism of Mallt Williams or depictions of religious faith or (romanticized) female agency-as well as the way wider class conflicts merge with industrial disputes. In the second half of the essay, we turn to look at themes and tropes in women's pre-war industrial fiction which would eventually reappear in men's working-class writing of the 1920s and 1930s. 
Industrial accidents and mining disasters are stock features of coalfields literature, included from the outset in women's writing. Female perspectives are privileged in Anne Beale's The Queen o' the May, which features a powerfully related colliery explosion told from the perspective of the frantic families of the victims and rescuers. The tense scene above ground would be repeated by Allen Raine and Irene Saunderson-the transfixed watchers by turns terrified and excited, the waiting punctuated by the movement of the pit cage, disgorging stretchers or taking in heroic rescuers.

The action goes underground in Raine's A Welsh Witch. Three men and a newly employed 12-year-old boy are trapped for several days after a roof fall caused by an explosion. They survive the afterdamp, but face starvation and madness. Stephen Knight suggests that Raine was "drawing on Joseph Keating's 1900 novel Son of Judith", but there is little to connect the two in style or plot. ${ }^{34}$ Jane Aaron instead identifies "accounts of a disaster at Tynewydd Colliery, Porth, in 1877, when four men and a boy survived entrapment underground for nine days", as the likely source of Raine's story, ${ }^{35}$ and many early novelists seem to have gleaned some basic information from newspapers, government reports or other non-fiction sources. ${ }^{36}$

If Raine focuses on a realistic account of men trapped below ground, the explosions in Anne Beale and Irene Saunderson provide an opportunity for female protagonists to demonstrate courage and strength. In The Queen o' the May, the heroine proves the value of her domestic skills, bearing restorative tea to exhausted miners, nursing the sick and injured, and offering emotional support and news to those unable to get to the pit. In A Welsh Heroine, when the men have done all they can, Morfydd goes underground to rescue the manager herself.

Although the drama of the fatal underground disaster remains a vivid literary reminder of the human costs of coal, more recent scholarship has focused on the fate of the maimed survivors of accidents and on the representation of disability in coalfields literature. ${ }^{37}$ With a high incidence of industrial accidents and chronic illness associated with the industrial and domestic environments of the coalfields, disability was the norm rather than the exception. Disability along with injury, disfigurement, sickness and the provision of care are important themes in women's industrial writing in this period. Caregiving could be bound up in the conservative gender ideology espoused in didactic writing, as in The Queen o' the May, which conforms to David Mitchell and Sharon Snyder's description of Victorian "instructional tales" which "evidence a penchant for discussing disability in terms of individual responsibility and the need for charity [in this case filial duty] towards the infirm". ${ }^{38}$ Indeed, the heroine's life, and therefore the plot of the novel, is determined by a series of domestic caring duties-for her aged great-grandfather, her cousin who was burned in a pit explosion, and, finally, her mentally ill father-for which she is duly rewarded with marriage and improved social 
status. Morfydd, in A Welsh Heroine, performs a similar role in caring for her frail Mamgu ("grandmother"), although she also earns money by taking in washing to help provide the nourishing food her aged relative needs.

While women remained the primary caregivers in late nineteenth- and early twentieth-century industrial centres, medical intervention and organized welfare systems were increasingly important-the strike in Joseph Keating's Son of Judith is to win the right to increase the weekly medical insurance money taken from the miners' pay. Coalfields were important sites for the development of medical services to deal with both emergencies and the longer-term health needs of disabled miners. Irene Saunderson, no doubt informed by her husband's profession, mentions medical details with some frequency in A Welsh Heroine, including "our new ambulance service" (38) and the use of "beef-tea tabloids" (310) to sustain overstrained colliers during a rescue below ground. Even the ongoing debate about pneumoconiosis and the health of colliers' lungs seems to lie behind a detailed description of "the blood coursing" in Morfydd's "veins", made "vigorous and buoyant" due to the mountain breezes "carrying the oxygen so necessary for the manufacture of good arterial blood" (94). Allen Raine tries to make a similar observation, erroneously claiming that, "fortunately for the colliers" who are covered from head to toe in coal dust, "it [coal dust] is not unwholesome, or their lives would be seriously endangered by the clogging of their skin". ${ }^{39}$ Clean skin was a significant concern for the Victorians, ${ }^{40}$ but inhalation was the real health issue; "by the 1860s it was accepted that miners suffered from a distinctive respiratory disease caused by inhaling coal dust", although it would be many decades before "miner's lung" was properly recognized. ${ }^{41}$

In addition to the incidental medical discourse in A Welsh Heroine, two of Saunderson's central characters are "disabled". One is a sympathetically portrayed itinerant grocer with a wooden leg, the other a malevolent figure whose body represents his character. Named for his deformity, "Jack-y-bandy" (bandy-legged Jack) has "crooked legs, cumbered [ ... ] with very large, flat feet" (20) that impede his movement, "a cadaverous face" (20) and "a very large head" (11), which lend him an "ungainly form" (13). Jack-y-bandy is an example of the long-standing connection between "sin and physical aberration". ${ }^{42}$ His body is an outward manifestation of his "stunted nature" (16): "His soul, like his body, was so cramped and warped, until all semblance of manliness had been lost, and in its stead a monster, abnormal and hideous in cruelty and meanness lived" (13).

The "medicalization" of disability which occurred in the nineteenth and twentieth centuries, where impairments were increasingly viewed as "conditions" to be remedied or "normalized", rested on a "dichotomy between normal and pathological". ${ }^{43}$ Or, to put it another way, "normality" is the condition to which disabled individuals are required to aspire. Jack-y-bandy is arguably restored to physical "normality" and spiritual health via 
self-sacrifice. Hitherto a bully and a coward, he heroically rescues colliers trapped in the mine following an explosion, before himself becoming trapped beneath a rockfall. Over two chapters, the rescue and his slow death and absolution are described without a single reference to his physical deficiencies (although he keeps his name almost to the end). In the closing paragraphs of the novel, the dead manager is "warmly cherished" (329) for his "self-sacrificing heroism" (330), while in the grave "a hero's body lies, broken and torn" (329, our emphasis). Arguably, the narrative remedies Jack-y-bandy's physical defects by omission in tandem with his spiritual restoration, but it also allows for a disabled body to be a hero's body.

Saunderson's treatment of the more attractive Jeremiah Jinkins is more subtle. Jinkins has a quasi-paternal role in this novel and, as such, is a double for the unpleasant Jack-y-bandy who, it turns out, is Morfydd's natural father. Jinkins finds laundry work for Morfydd during the strike and gives her the occasional gift of money or food, despite his status as a renowned miser. He is not defined by his disability-unlike Jack-y-bandy, who is named for his crooked legs-and neither his amputation nor his prosthesis symbolizes his character or soul, although his leg does render him a slightly comic figure, from the tap-tapping of his walk to his "affectionate" (101) regard and "customary study of his leg" (103), which are linked to his humorous portrayal as a "philosopher" (76).

Disability critics Mitchell and Snyder have argued that disability requires (and engenders) a narrative. ${ }^{44}$ The circumstances of Jinkins' first amputation are not related. Instead, Jinkins and his prosthesis are at the centre of a comic interlude which is intended to introduce us to the wider community in an essentially ethnographic passage. ${ }^{45}$ After some banter with the local women, who will not buy his produce in the face of an impending strike, Jinkins tries to stop his wayward pony from darting off with his merchandise by sticking his leg, "which happened most fortunately to be wooden" (73), into the spokes of the cartwheel. It shatters, leaving "Mr. Jinkins sitting on the ground, with an expression of the supremest surprise upon his usually phlegmatic countenance" (73). The comedy continues as bystanders ask if Jinkins is in pain and congratulate him on using the wooden leg rather than the other leg; eventually the doctor arrives, only to be dismissed: "It be the carpenter I do want, syr" (76). The self-importance of Jinkins deserves to be punctured, but, in fact, Saunderson's treatment of this incident, and in particular the way in which she describes the prosthesis-at once a part of his body and yet an inanimate and replaceable appendage-reveals a more serious interest in the body and its boundaries. The comedy of the scene depends on the dual nature of the prosthetic leg as body part and prosthesis, both "my leg" and a "limb" (74) and, at the same time, a "ragged stump" of wood (73). The fluid status of the prosthesis-the "remnant of what a short time previously had 
composed part of his anatomy" (73) - is finally underlined in the rather uncanny afterlife of the leg:

The portion that was snapped off from the wooden leg, reposed that night, wrapped up in an old shawl within the arms of a little child who had found it lying a yard or two away from the accident.

"Bye-bye, dollie," crooned the child, as she hugged her treasure-trove, and closed her eyes for the night. (80)

The ubiquity of industrial accidents and casual "minor" injuries is also utilized as a plot device in Amy Dillwyn's fiction. Disfigurement and disability in an industrial landscape are important elements of the detective plot of A Burglary, or Unconscious Influence (1883). The burglary of the title involves a wealthy heiress being tied to her bed by a man disguised as a "poacher", who then makes off with her jewels. He is, in fact, a gentleman thief, but his working-class disguise-and, in particular, the fact that he is missing a finger-successfully deflects attention onto a local collier and "notorious" poacher. In the eyes of the squire and local magistrate, a poacher is "capable of any iniquity", and he believes that he has found his man. ${ }^{46}$ In his defence, the miner's wife points out the ubiquity of maimed colliers: "what with drams slipping, and stones falling, and one thing and another, there be always something wrong at them collieries". ${ }^{4}$

The industrial landscape in which Dillwyn's characters reside is a potential danger in more than one novel. Several characters meet their end in industrial workings: by falling down a disused quarry (Jill and Jack, 1887); being thrown down an abandoned mine and left to perish (The Rebecca Rioter, 1880); dying from a blow to the head inflicted by refuse falling from a slag heap ("Nant Olchfa", serialized 1886-87); or being crushed and burned to death by a white-hot steel ingot (in the same novel). This last is a rare instance of a literary description of this kind of industrial accident, and Dillwyn offers a detailed and gruesomely realistic account of the event. The upper-class villain, disguised as a workman, gets into the path of men moving an ingot at speed to the "great hammer which was to beat it into shape". They try to stop, but the ingot shoots off the trolley:

There was a sound of a heavy body hurtling through the air, a shriek of sudden pain and terror, a crash, and then Reginald lay writhing and screaming on the ground, with his legs crushed beneath the weight of more than a ton of steel at nearly white heat. Then ensued a ghastly scene, whose recollection haunted those who witnessed it for many a long day afterwards.

The first necessity was to procure long iron bars as levers, wherewith people could prize up the superincumbent mass of burning metal from off him, without approaching nearer to its fiery heat than flesh and blood could endure. [...] [W]hilst they were being hunted for and dragged to the spot, the sufferer had to lie in agony, with crushed limbs, and exposed defenceless to the heat that scorched and blistered him cruelly, and yet did not destroy consciousness. ${ }^{48}$ 
The scene goes on at some length, detailing the man's protracted agonies. Although Dillwyn, like Keating in Son of Judith, relies on a story which focuses on the "quality" rather than the ordinary workers, who were the most likely to be injured in the steel or coal industries, pioneering scenes such as this constitute an important and early fictional encounter with the dangers of heavy industry.

The middle- and upper-class women writers discussed here adopted romance as a flexible means to explore the industrial themes, scenes and settings which were transforming Wales-economically, linguistically, ethnically and politically -in the late nineteenth and early twentieth centuries. Irene Saunderson, who was the most immersed in the "colliery life" she wrote about, went furthest in trying to represent the bilingual, Nonconformist working-class world she inhabited with her husband, a doctor in the coalfields. The romantic alliance between an upper-class English officer and a working-class Welsh girl may seem absurd, detracting from both the astute ethnographic detail of her writing and her feisty working-class heroine. But melodrama also allowed Saunderson to represent the heightened class conflict that would, indeed, explode in a lethal confrontation between army and workers shortly after her novel was published. Other women writers were more concerned with a generalized class conflict, seeing the struggle in the mines as connected to wider inequities shared by rural workers, connecting scenes of industrial unrest with riots and poaching in the border zones where industry and rural life merged. Still others found a framework for transposing nationalist resistance onto working-class solidarity; indeed, what is perhaps most striking is the markedly and self-consciously Welsh character of all the texts, which seem indebted to the contemporary Young Wales movement. In writing about colliery life, these writers foregrounded disability and care work alongside the more sensational disasters, industrial action and community cohesion which we tend to associate with later industrial literature. Taken as a whole, then, these early fictional representations of heavy industry in Wales constitute an important body of work that expands what we understand as industrial fiction.

\section{Notes}

1. Raymond Williams, "The Welsh Industrial Novel", Who Speaks for Wales: Nation, Culture, Identity, ed. Daniel Williams (Cardiff: U of Wales P, 2003), pp. 95-111 (99). Though set close to a mining district, Felix Holt does not depict colliery life. On the wider contribution of women to early industrial writing, see Joseph A. Kestner, Protest and Reform: The British Social Narrative by Women, 1827-1867 (Madison: U of Wisconsin P, 1985).

2. Susan Zlotnick, Women, Writing and the Industrial Revolution (Baltimore: John Hopkins UP, 1998), p. 229; Martha Vicinus, The Industrial Muse: A Study of Nineteenth Century British Working-Class Literature (London: 
Croom Helm, 1974); Catherine Gallagher, The Industrial Reformation of English Fiction: Social Discourse and Narrative Form, 1832-1867 (Chicago: U of Chicago P, 1988). Even Kestner, who discusses Fanny Mayne's novel (below), fails to index mining or other heavy industries.

3. Mayne's heroine is a seamstress, but also the daughter of a collier and strike leader. Kestner argues that "Mayne attributes fifties reforms to a period in which they were at best initiated" (177). Mayne was editor of The True Briton (in which Jane Rutherford was serialized); here she also published articles on industrial topics and claimed to have been underground (180). Other early writing about coal includes a short religious tract, The Lancashire Collier Girl (1795), by Hannah More. Fiction by men includes Robert Douglas's (also known as The Medical Student) "The Miners: A Story of the Old Combination Laws" (1844) and G. Wharton Simpson's “Colliers and Coal Mining” (1851).

4. There are earlier examples of poems and ballads by women which acknowledge heavy industry in Wales. See, for instance, Jane Aaron's discussion of Elizabeth Davies of Neath in Nineteenth-Century Women's Writing in Wales: Nation, Gender and Identity (Cardiff: U of Wales P, 2007), p. 190. Male novelists were active at about the same time. A Welsh-language novel, Arthur Llwyd (1879) by John Thomas, depicts the opening of a coal mine, while Joseph Keating, a former miner, published Son of Judith: A Tale of the Welsh Mining Valleys in 1900. In addition, several Wales-set mining novels were published, including Israel Mort, overman: a story of the mine (1873-76) by the Devon-born writer John Saunders and Rhoda Roberts: a Welsh mining story (1895) by Harry Lindsay who spent at least part of his teaching career in Wales.

5. Rachel Blau DuPlessis, Writing beyond the Ending (Bloomington: Indiana UP, 1985), p. 19. In their studies of "race melodrama" and "border romance", Susan Gillman and Rita Keresztesi tease out the ways in which "this genre [romance] accommodates the intercultural, interracial, international, and historically determined personal encounters that make up what Fredric Jameson calls the 'political unconscious' of a nation". Rita Keresztesi, "Romancing the Borderlands: Josephina Niggli's Mexican Village", Doubled Plots: Romance and History, ed. Susan Strehle and Mary Paniccia Carden (Jackson: UP of Mississippi, 2003), pp. 107-26 (113). See also Susan Gillman, “The Mulatto, Tragic or Triumphant? The Nineteenth-Century American Race Melodrama", Culture of Sentiment: Race, Gender and Sentimentality in 19th-Century America, ed. Shirley Samuels (New York: Oxford UP, 1992), pp. 221-43.

6. Stephen Knight, A Hundred Years of Fiction: Writing Wales in English (Cardiff: U Wales P, 2004), p. 30.

7. Williams, p. 102.

8. Knight, p. 31.

9. David Painting, Amy Dillwyn (Cardiff: U of Wales P, 1987).

10. The story was first serialized in The Girl's Own Paper, 9 October 1880-9 May 1881 (and a sequel, entitled "May Goldworthy", appeared there in 1881-82). The single-volume edition was published by the Religious Tract Society in 1881 .

11. The date of publication is usually given as 1911, but there is documentary evidence to support the earlier date of 1910. The preface is dated April 1910, and reviews of the novel appeared in the summer of 1910, including one in June in the Rhondda Leader, followed by another on 11 August in the South Wales Daily Post, while the same paper reported on 30 June that a copy of the 
novel had been accepted by the King. The earlier date would contradict Knight's assertion that Saunderson's riot scene is based on the Tonypandy riots of November 1910-11.

12. "Mumbles Lady in Canada", The Cambrian, 1 Sept. 1905, Welsh Newspapers Online, <http://newspapers.library.wales/>.

13. The term is used by Lewis Jones in his preface to Cwmardy (London: Lawrence and Wishart, 1937), n. pag.

14. Anne Beale, The Queen o' the May (London: Religious Tract Soc., 1881), p. 131.

15. Mabel Holland Grave, Fraternity: A Romance, vol. 1 (London: Macmillan, 1888), p. 173.

16. Aaron, pp. 169-71 (the quotations are from Grave).

17. Aaron, p. 170.

18. Grave, p. 185.

19. H. Gustav Klaus, "The Strike Novel in the 1890s", The Rise of Socialist Fiction 1880-1914, ed. Klaus (Brighton: Harvester, 1987), pp. 73-98 (94).

20. E. A. [Amy] Dillwyn, Chloe Arguelle, vol. 1 (London: Tinsley Bros., 1881), p. 244.

21. Hereford Times, 18 Jan. 1879; qtd. in David Jones, "The Second Rebecca Riots: A Study of Poaching on the Upper Wye", Llafur, 2.1 (1976): 32-56 (34).

22. The Dau Wynne [Mallt Williams], A Maid of Cymru: A Patriotic Romance (London and Carmarthen: Simpkin Marshall and W. Spurrell, [1901]), p. 173. Subsequent references are to this edition and given parenthetically in the text.

23. Katie Gramich discusses the colonial comparisons further in TwentiethCentury Women's Writing in Wales: Land, Gender, Belonging (Cardiff: U of Wales P, 2007), pp. 17-21.

24. Irene Saunderson, A Welsh Heroine: A Romance of Colliery Life (London: Lynwood and Co., 1910), p. 81. Subsequent references are to this edition and given parenthetically in the text.

25. Klaus, 80 .

26. M. Wynn Thomas, In the Shadow of the Pulpit: Literature and Nonconformist Wales (Cardiff: U of Wales P, 2010), p. 27.

27. Thomas, p. 39.

28. "Cymru dros byth" is intended to mean "Wales for ever". While the grammatically correct form is "Cymru am byth", this form of the motto was often given in nineteenth-century English publications.

29. A Welsh Heroine is dedicated to the principal of the Calvinistic Methodist theological college in Bala, north Wales, and a marked, but not dogmatic, Christian ideology underpins the novel.

30. Thomas, p. 14 .

31. Philip Jenkins, A History of Modern Wales 1536-1990 (Abingdon: Routledge, 2014), p. 196.

32. Allen Raine, A Welsh Witch: A Romance of Rough Places (Dinas Powys: Honno, 2013), p. 305.

33. Beale, p. 134.

34. Knight, p. 22.

35. Jane Aaron, introduction, Raine, pp. ix-xxii (xviii).

36. The novelist John Saunders even footnotes his non-fictional source-Louis Simonin's Underground Life: Mines and Miners (1869), a translation from the French-in Israel Mort, Overman: A Story of the Mine, vol. 3 (London: Henry S. King, 1876), p. 71. 
37. See the interdisciplinary Wellcome Trust-funded project "Disability and Industrial Society: A Comparative Cultural History of British Coalfields 1780-1948”, $<$ http://www.dis-ind-soc.org.uk $>$.

38. David T. Mitchell and Sharon L. Snyder, Narrative Prosthesis: Disability and the Dependencies of Discourse (Ann Arbour: U of Michigan P, 2000), p. 26.

39. Raine, p. 249.

40. Mieneke Te Hennepe, “To Preserve the Skin in Health': Drainage, Bodily Control and the Visual Definition of Healthy Skin 1835-1900”, Medical History, 58.3 (2014): 397-421.

41. Arthur McIvor and Ronald Johnston, Miners' Lung: A History of Dust Disease in British Coal Mining (Aldershot: Ashgate, 2013), p. 66.

42. David M. Turner, "Introduction: Approaching Anomalous Bodies", Social Histories of Disability and Deformity, ed. David M. Turner and Kevin Stagg (Abingdon: Routledge, 2006), pp. 1-16.

43. Bradley Lewis, "A Mad Fight: Psychiatry and Disability Activism", The Disability Studies Reader, ed. Lennard J. Davis, 4th ed. (Abingdon: Routledge, 2013), pp. 115-31 (116).

44. Mitchell and Snyder, Narrative Prosthesis.

45. We are borrowing Stephen Knight's terminology here (15). Saunderson's ethnography is particularly focused on the detail of women's lives, noting, for instance, the practical clothing worn by a breastfeeding woman: "the front of whose untidy bodice was open, revealing a strip of pink calico, an article of dress greatly affected by the married section of the feminine community of Cwmglo when suckling their infants, being considered by them more 'handy' than the opening of hooks and eyes for the purpose" (67). Elsewhere, a curious mixture of sentimental and medical language is used to describe breastfeeding mothers, whose happy tears on finding their husbands saved "mingl[e] $[\ldots]$ with the lacteal refreshment wherewith they sought to soothe their little, wailing human burdens" (322).

46. Amy Dillwyn, A Burglary, or Unconscious Influence (Dinas Powys: Honno, 2009), p. 82.

47. Dillwyn, Burglary, p. 96.

48. E. A. [Amy] Dillwyn, "Nant Olchfa: Chapter XX", The Red Dragon: The National Magazine of Wales, 11 (Jan.-June 1887): 289-99 (296-97).

\section{Acknowledgments}

This essay has been written as part of the Wellcome Trust Programme Award, 'Disability and Industrial Society: A Comparative Cultural History of British Coalfields, 1780-1948' [095948/Z/11/Z]. It draws on the work of the research team: Professor Anne Borsay, Dr David Turner, Dr Kirsti Bohata, Dr Daniel Blackie, Dr Mike Mantin and Alexandra Jones (Swansea University); Dr Steven Thompson and Dr Ben Curtis (Aberystwyth University); Dr Vicky Long (Glasgow Caledonian University) and Dr Victoria Brown (Northumbria University/Glasgow Caledonian University); and Professor Arthur McIvor and Dr Angela Turner (Strathclyde University).

\section{Disclosure statement}

No potential conflict of interest was reported by the authors. 


\title{
GWYNETH VAUGHAN, ELUNED MORGAN AND THE EMANCIPATION OF WELSH WOMEN
}

\author{
Rosanne Reeves and Jane Aaron
}

\begin{abstract}
Cymru Fydd, the Welsh Home Rule movement of the 1880s and 1890s, included female suffrage as one of its goals, and envisioned its proposed Welsh National Assembly as including elected female members. Beriah Gwynfe Evans, an activist within that movement, introduced into his satirical novel Dafydd Dafis (1898) an episode in which his protagonist, in a prophetic dream, sees the allegorical figure of "Woman Enslaved" freed from her bonds by nine female helpmates, all well-known historical figures of the period. Two of those nine heroines, depicted in the cartoon which illustrated his dream and which also appears on the cover of this journal, were Welsh-language writers. The novelist Gwyneth Vaughan is shown aiming a blow with her "Woman Suffrage" broom against "Man the Oppressor", while the travel writer Eluned Morgan also stands ready to aid in the freeing of "Woman Enslaved". After an introductory account of the relation between Cymru Fydd and the women's movement, this article focuses on the contribution of these two writers to the emancipation of Welsh women. Vaughan's novels O Gorlannau y Defaid (From the Sheepfold, 1905) and Plant y Gorthrwm (The Children of the Oppression, 1908), along with Morgan's Dringo'r Andes (Climbing the Andes, 1904), Gwymon y Môr (Seaweed, 1909) and Ar Dir a Môr (On Land and Sea, 1913), are explored to assess the degree to which they did indeed aid in freeing Woman from her chains.
\end{abstract}

In 1895, "the political enfranchisement of women" was strongly advocated in the pages of the journal Young Wales, the mouthpiece of Cymru Fydd (literally, "The Wales That Is To Be"), by one of its regular columnists, Nora Philipps. ${ }^{1}$ Led by the radical Liberal Members of Parliament Thomas E. Ellis and David Lloyd George, Cymru Fydd, a Welsh Home Rule movement closely linked to the Liberal Party, was at that time confident of achieving its goals, as evinced by the optimistic footnote which the editor of Young Wales appended to Philipps' first column:

Our readers will be interested to learn that Mrs Philipps has been elected a member of the Parish Council of Manorbier. We trust that the day is not too far distant when Mrs Philipps and other leaders of the Women's Movement 
in the Principality will be elected to a duly-established Welsh National Assembly. ${ }^{2}$

In the event, of course, Welsh women had to wait another 30 years before the passing of the Equal Franchise Bill gave them the vote on the same terms as men, and over a century before the 1997 Devolution Referendum gave Wales its first National Assembly. But as Nora Philipps noted in her columns, quoting from the movement's manifesto, Cymru Fydd had in 1895 "identified itself in the woman's cause" and "pledged itself to 'promote legislation with a view to secure equal rights of citizenship for women with men"', 3 thus becoming "the first major party organization in Britain to include women's suffrage amongst its objects". 4

Thirty years earlier, if two historians of the Welsh settlement in Patagonia are to be believed, a precedent had been established for such a progressive approach to female suffrage amongst advocates of Welsh independence when, in 1865, an attempt was made to establish a self-governing Welsh colony in South America. Partly as a result of the growing tendency amongst Tory landlords to evict their Welsh tenants for voting Liberal, mid nineteenth-century Welsh radicals were resorting to emigration in increasing numbers. Michael D. Jones, principal of the Congregational College at Bala from 1855, suggested that if those wishing to emigrate established themselves in one area en masse, rather than dispersing themselves across the British colonies, it would give the Welsh language and its culture a second base. The 1847 report on education (discussed in Gwyneth Roberts' contribution to this issue), and the English-language schooling it promoted, threatened the survival of the language in its homeland. "Our children are taught in English schools [...] English managers curse the Welsh in almost all of our factories", Jones complained in 1862, arguing that a self-governing émigré community, with Welsh as its official language of governance, could provide a safer environment in which the language could flourish. ${ }^{5}$ Patagonia in Argentina was chosen as the site for this experiment and, before the first shipload of Welsh settlers left Liverpool for South America, their new constitution had been drawn up. ${ }^{6}$ The community was to function cooperatively, in accordance with the settlers' belief that "common interests coincided with individual interests", and to be led by a Settlement Council, in the election of which "everyone over eighteen years of age, both male and female, was guaranteed a vote by secret ballot".

Unprecedented in the 1860 s, such a decision to give women the vote could also, arguably, like the settlement in Patagonia itself, have been one of the long-term consequences of the Welsh reaction to the 1847 report on education in Wales. The report had accused Welsh women in particular of primitive sexual immoralities, proclaiming that "want of chastity is the giant sin of Wales". Intent as they were on proving the falsity of such claims, the leaders of Welsh 
society in the second half of the nineteenth century were eager to promote the public advancement of Welsh women. A number of women availed themselves of the opportunity to exert influence on behalf of their sex. The members of the Association for Promoting the Education of Girls in Wales, for example, were from 1886-1901 active in the establishment of the Welsh Intermediate Education Act of 1889 and in the decision of the University of Wales, when it obtained its charter in 1893 , not only to grant degrees to women, but also to open its doors to them as employees on the same terms as men.'

Many of these prominent female public figures, including Nora Philipps, are featured in a prophetic "vision" which haunted the sleep of the central character in Beriah Gwynfe Evans' novel Dafydd Dafis (1898). Beriah Evans was the organizing secretary of Cymru Fydd in 1895 when, in its annual convention, it "warmly supported" Nora Philipps' motion that "To secure for women equal rights of citizenship with men" should be included amongst the movement's aims. ${ }^{10}$ His novel, first published in serialized form in $Y$ Genedl Gymreig from 1892-94 and subtitled Hunangofiant Ymgeisydd Seneddol (The Autobiography of a Parliamentary Candidate), is a humorous portrayal of Welsh Liberal Members of Parliament in Westminster during the Cymru Fydd epoch. Dafydd Dafis has succeeded in the dairy trade in London with the help of his energetic and capable wife, and it is her ambition rather than his own which drives him on to stand for Parliament. Many of the text's comedic episodes concern the misunderstandings between the sophisticated wife, Claudia, and her naïve husband; Dafydd admires and respects his spouse (the tenderness between them is underlined in the penultimate chapter in particular), but is at the same time harassed by her vicarious concern for his social advancement, which he mocks. Admiration and satire are also subtly combined in his representation of Welsh women's involvement in the suffrage movement. Driven to a fever by his Westminster troubles, Dafydd Dafis has a dream in which he sees

Y Ddynes yn cael ei llethu i'r ddaear gan bwysau ei beichiau o bob math, ac yn rhwym draed a dwylaw gan gadwyni Israddoldeb. Gyferbyn a hi safai Dyn y Gorthrymwr, gyda Chwip Awdurdod yn ei law ac ysnoden Gormes Deddf ar ei fynwes, tra Gwyneth Vaughan, ac Ysgubell Pleidlais i Ferched yn anelu ergyd dialeddol at ei benglog! Yr oedd Gertrude Stewart a Ffeil y Fôt yn tori ymaith gadwynau'r Ddynes, a'r Arglwyddes Henry Somerset yn tynu ei beichiau yn rhydd; dygai Mrs Wynford Philipps Gawg Meddyginiaethol y Women's Institiwt i olchi ei briwiau; brysiai Mrs Howell Idris yn mlaen gyda Threi Rhyddid i'w hadfywio; dygai Mrs Brynmor Jones hithau fasgedaid o ffrwythau hyfryd Graddau Prifysgol i dori syched y druanes am Wybodaeth; tra fel angylesau gwasanaethgar yn barod i gynorthwyo yn mhellach yr oedd llu o rai eraill yn cael eu blaenori gan Miss Gee, Edith Oldham, a'r Fonesig Eluned

[Woman oppressed to the earth by the weight of her burdens of every kind, and bound hand and foot by chains of Subordination. Opposing her stood Man the 
Oppressor, with the Whip of Authority in his hand, and the ribbon of Legal Oppression on his breast, while Gwyneth Vaughan with the broom of Votes for Women aimed a revengeful blow at his skull! Gertrude Stewart with the Vote File was breaking asunder the Woman's chains, and Lady Henry Somerset relieving her of her burdens; Mrs Wynford Philipps (i.e. Nora Philipps) brought the Medicinal Bowl of the Women's Institute to wash her bruises; Mrs Howell Idris hurried forward with the Tray of Freedom to revive her; and Mrs Brynmor Jones brought a basket of the luscious fruit of University Degrees to slake the poor creature's thirst for Knowledge; while like ministering angels ready to render further assistance there were a host of others led by Miss Gee, Edith Oldham, and the Lady Eluned]. ${ }^{11}$

For all its semi-satirical tone, ${ }^{12}$ the vision's cast of characters includes figures of indubitable historical significance in the promotion of female emancipation: Gertrude Stewart, for example, was the secretary of the Central and Western Women's Suffrage Society, which included Wales, while Lady Isabella Somerset led the British Women's Temperance Association (BWTA), which advocated women's suffrage as part of its campaign. Each figure is portrayed with some success in terms of facial likeness in the cartoon by $\mathrm{Ab}$ Caledfryn (William Morgan Williams) entitled "The Emancipation of Woman", which accompanied Dafydd Dafis's account of his vision (see Figure 1). ${ }^{13}$ Two of the nine women portrayed were writers: Gwyneth

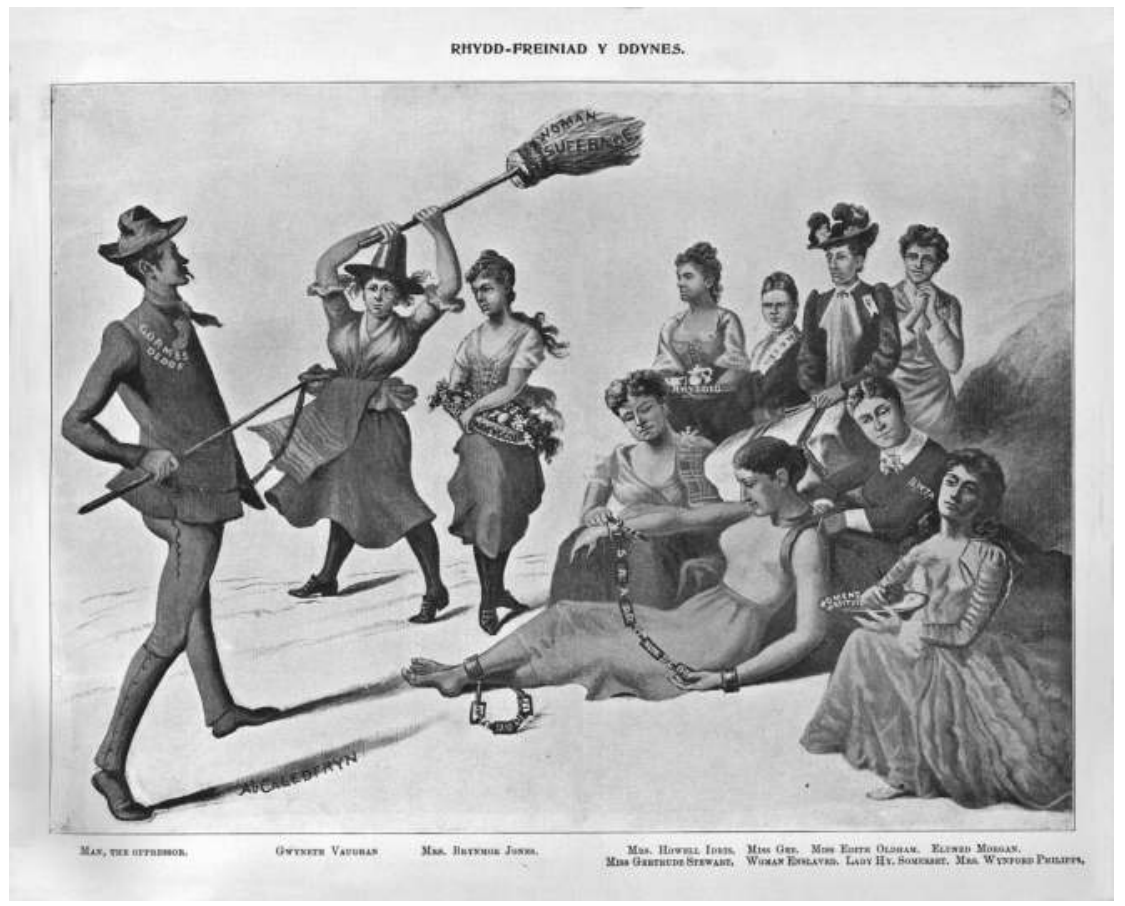

Figure 1. Ab Caledfryn, 'Rhydd-freiniad y Ddynes' (The Emancipation of Woman, 1898). 
Vaughan (Annie Harriet Hughes, 1852-1910) of Talsarnau, Merioneth, and Eluned (Eluned Morgan, 1870-1938) of Patagonia. In 1898, however, when Dafydd Dafis was published, neither of these two women had, in fact, as yet produced the works which were to make them well known in Wales in the first decade of the twentieth century. Given that other established Welshlanguage authors, like, for example, Cranogwen (Sarah Jane Rees), the editor of the women's journal Y Frythones, or her protégée the "New Woman" essayist Ellen Hughes (Elen Engan), were already well known for their promotion of the women's cause,${ }^{14}$ it seems at first surprising that two at the time less prominent writers should be featured here. Why, in 1898, choose Gwyneth Vaughan and Eluned Morgan as representative Welsh emancipators of their sex, and to what extent did their later works fulfil this prophetic vision of their role? The rest of this article explores possible answers to these questions.

\section{Early careers}

Neither Gwyneth Vaughan nor Eluned Morgan was born to privilege. Gwyneth Vaughan's father, Bennet Jones, was the local miller in Talsarnau; her formal education came to an end at the age of 14 when she was apprenticed to a milliner. Her prospects improved, however, in 1875 when, employed as a shop assistant in Caernarfon, she married the son of the shop, John Hughes Jones, and encouraged him to become a doctor. They moved to London and had four children, but Dr Jones succumbed to alcoholism, while his wife, no doubt not coincidentally, became, in the words of the historian of the suffrage movement in Wales, "the most dynamic of BWTA activists [...] who claimed to have organized as many as 243 branches" of that temperance association. ${ }^{15}$ The family returned to Wales in 1888 , to Treherbert in the Rhondda Fawr, where Dr Jones found work as a medical man in the coal mines and his wife continued her crusade, delivering her first public lecture in Wales in a Wesleyan chapel in Treherbert in 1891. A report on another of her public addresses, published in the Merthyr Times in 1893, suggests that, like other members of the BWTA, she combined campaigning for women's suffrage with the promotion of temperance: apparently, she told her hearers that "the greatest help that could be given to the temperance cause would be the enfranchisement of women (hear hear)". ${ }^{16}$

By the early 1890s, she had also started to pursue a career as a writer. In 1892, she was contributing a regular column to the Welsh Weekly, including a "questions and answers" section in which she frequently found cause to speak against those who opposed female self-improvement. "No", she says to "Medica", who wrote to her for advice, "we do not think 'going for a degree unsexes a woman.' [...] By all means go on as you have begun, and pay no attention to narrow-minded critics". ${ }^{17}$ By 1894 , she was also furthering 
the suffragist cause in Welsh-language periodicals, with a "Women's Column" in the weekly $\mathrm{Yr}$ Eryr, in which, for example, she tells a correspondent concerned about taxation that: "Fel y gwyddoch, y mae gîr a gwraig yn cael eu hystyried yn un, ac hyd yn hyn yr un hwnnw yw y gîr [As you know, man and wife are considered one, and up to now that one has been the man]". ${ }^{18}$ But the times were changing. When the Local Government Act of 1894 finally allowed women to stand in district council elections, Gwyneth Vaughan, who in 1892 had moved with her family to Caernarfonshire, was elected a member of Gwyrfai District Council, and she soon became also a member of the Caernarfon Joint Health Committee and the first ever female member of the Caernarfon Board of Guardians.

From the first, Vaughan combined her advocacy of the suffragist cause with active support of the Welsh Home Rule movement. It was during the years of her sojourn in London that the Cymru Fydd movement was established in that city in 1886 by a group of young London-Welsh Liberals. In the 1890s, Welsh suffragists who had put their trust in the Liberal Party to fight for "Votes for Women" established a large number of Women's Liberal Associations throughout Wales, aiming, according to Ursula Masson, "to bring feminism and nationalism together, and to feminise the discourses of Welsh nationhood". ${ }^{19}$ In 1895, Gwyneth Vaughan took on the joint co-secretaryship of the Welsh Union of Women's Liberal Associations, and three years later, in 1898, was elected its sole Honorary Secretary-a position she retained until March 1907. She also contributed to the women's pages in Young Wales, in 1897 telling its readers that:

$[\ldots]$ it is with a glad heart that I feel that the men of my own land are in the vanguard of reform [...] The men of Wales encourage their mothers, wives, sisters and daughters in their highest aspirations [...] and rejoice with them in all their achievements. We have John Bull as usual lagging behind in his own thick-headed fashion. ${ }^{20}$

In such articles, Welsh Home Rule and women's suffrage are seen as two aspects of a multifaceted progressive move towards enhanced equality. Nor are the particular difficulties facing the underprivileged class into which Gwyneth Vaughan was born forgotten. She emphasizes the importance of ensuring every woman's economic independence: "Let us not rest content until every girl holds in her own hand a bread winning weapon", she argues, "for the economic position of women must attain its proper level before it is possible for them to take their places on that higher platform we would fain see them occupy". "To-day", she concludes,

$[\ldots]$ at the close of the century we may sum up the outlook by saying that women have the future in their own hands. If we show that we deserve liberty, it will be ours sooner than perhaps many of us think. ${ }^{21}$ 
"Every feminist struggle has a specific ethnic (as well as class) context", or so Floya Anthias and Nira Yuval-Davis emphasized in the $1980 \mathrm{~s} ;{ }^{22}$ more than one axis of social inequality will always affect each particular struggle towards greater female emancipation. By the 1990s, feminists working within the black women's movement had evolved a conceptual term for the study of such multiple axes of inequality: "intersectionality" - a term today increasingly employed in feminist analysis to "explore the way in which domination, subordination and subjects are constructed in particular locations and contexts". ${ }^{23}$ But, of course, the fact that in particular contexts women could experience more than one aspect of their identity as subject to oppression had been recognized much earlier. Nora Philipps quotes Mary Wollstonecraft on the multiple identities of women as citizens, as mothers and as "rational creatures" in their own right when making the point in one of her 1896 Young Wales columns that, in matters affecting the women of Wales, "Laws and Customs have been more repressive than in England". But now, she adds, at the height of the Cymru Fydd movement, "the inherent forces in the nation, no longer repressible, have burst forth", and "the women of Wales [...] can now uplift their own standard to encourage their sisters across the border" ${ }^{24}$ By 1898, although the publications through which she was to make her name still lay in the future, Gwyneth Vaughan also had already made clear her recognition of the ethnic context of her own feminist struggle. She too uplifts a specifically Welsh banner in the general march towards female emancipation, and thus is suitably portrayed clad in full Welsh national costume as she strikes her blow against "Man the Oppressor" in Ab Caledfryn's cartoon.

What Eluned Morgan is doing amongst this band of fin-de-siècle suffragists seems initially more difficult to substantiate; there are few explicit references to the women's suffrage movement in her writings, both before and after 1898, and her first publication, Trevnusrwydd Teuluaidd (Domestic Orderliness, 1892) , an essay of advice to Patagonian women on household management, emphasizes the importance of women's role in the home. ${ }^{25}$ Eluned, as she was often later to sign herself, was born at sea, on board the second ship to carry Welsh settlers to Patagonia, and reared on the banks of the Camwy under the difficult conditions which initially faced the settlers as they struggled to make a living on prairie land beset by drought. ${ }^{26}$ But after one of the female settlers, Rachel Jenkins, had "proposed the systematic use of canals", Argentina's "first ever irrigation system" was established in the area, ${ }^{27}$ which consequently prospered and, by the mid 1880s, could boast a "flourishing economy based primarily upon the cultivation of wheat". ${ }^{28}$ In 1885, Eluned Morgan was sent to Wales to study at Dr Williams' School, Dolgellau, which, like the majority of post-1847 educational establishments in Wales, had a strict English-only linguistic rule. Admonished for speaking Welsh at the dinner table, Eluned, who at the time had very little English, used the opportunity 
to rouse her fellow pupils to protest, as she explained some years later in a letter to her friend William George, David Lloyd George's brother:

[...] gorchmynwyd i mi sefyll allan tra yr oedd 80 o blant yn gorphen eu cinio ac yn syllu arnaf, ond nid oedd yr athrawes yn adnabod ei deryn o'r Paith - "Pob Cymraes yn yr ystafell yma nad oes arni gywilydd arddel ei gwlad na'i iaith, a ddeuwch gyda mi i'r Classroom?" Cododd pob Cymraes yn yr holl ysgol ac aethant allan gan adael rhyw 30 o Saeson gyda'r Athrawesau. Bu yn helynt difrifol yno am wythnos

[I was ordered to stand out, while 80 children finished their dinner and stared at me, but the teacher did not know her bird from the Prairie- "Every Welsh girl in this room who is not ashamed to acknowledge her country and her language, will you come with me to the Classroom?" Every Welsh girl in the school rose and went out, leaving some 30 English girls with the teachers. For a week there was serious trouble]. ${ }^{29}$

"Standing out" and receiving the full attention of her schoolmates was intended as a humiliating punishment, but Eluned took the prominence it gave her as a public platform from which to lead a revolt.

Interestingly, she attributes her boldness in so doing not to her individual character, but to the particular geographical and political context of her upbringing. The implication is that, as a "bird" of the wild prairie, reared in an isolated Welsh-speaking community of committed radicals, she was not socially conditioned to be either ashamed of her language or subservient in a stereotypically feminine fashion. Given that Eluned's father, Lewis Jones, a printer by trade, was a founding member of the Patagonian enterprise, one of its elected leaders and editor of its Welsh-language newspaper, Y Dravod, the qualities of leadership his daughter evinced were no doubt attributable in part to his influence. Yet Eluned herself insists that such courage and selfreliance as she possessed she shared with her Patagonian sisters generally. As she explained to William George: "nid oes neb morwynion i'w cael yn y Wladfa-pawb yn gydradd [there are no servant maids to be had in the Settlement-everybody is equal]" 30 - to her a welcome state of affairs, she says, in its eschewal of hierarchies and enforcement of self-reliance. After her return to Patagonia, she helped with the writing, editing, typesetting and printing of $Y$ Dravod, for the production of which she often bore sole responsibility when her father was required to visit Buenos Aires. ${ }^{31}$

She also started to send articles describing the way of life of the Welsh settlers in Patagonia to Welsh-language periodicals published in the home country-articles which frequently make reference to the effect of a prairie upbringing on gender identity. In an 1897 number of the journal Cymru, for example, she charges her readers to remember that they have

[...] frodyr a chwiorydd tros y Werydd a fagwyd mor dyner a neb o honoch, ond a ganasant ffarwel i bob cysuron er mwyn cadw'n fyw eu hiaith 
[brothers and sisters across that Atlantic who were reared as tenderly as any of you, but who bade farewell to every comfort in order to keep their language alive]. ${ }^{32}$

None of the Welsh reared in Patagonia have been conditioned into passivity or dependence, she claims in a further 1897 contribution to the journal Heddyw: they "Nid oes gruddiau fel y rhosyn a'r lili ganddynt, ac nid yw eu dwylaw yn wynion a lluniaidd [do not have cheeks like the rose and the lily, and their hands are not white and shapely]". Rather, their hands "lluniwyd eu dwylaw i arwain yr aradr a'r ôg i ben y gwys heb droi'n ôl [were formed to drive the plough and harrow to the furrow's end without turning back]". ${ }^{33}$ Consequently, they may appear "dipyn yn amrwd a garw i lygaid moethus, ond yn bur a glew, ac yn Gymry pybyr [a little raw and rough to the refined gaze, but they are true and brave, and staunchly Welsh]". Courage, endurance and self-resourceful independence are as much feminine as masculine attributes, she implies; it is the specific social, geographical and political context which works to mould gender attributes, not any essential sex factor.

What Eluned Morgan brought to the task of freeing woman from her chains, then, was, from the first, a radically different perspective on the nature of womanhood than that of the "refined gaze" of late nineteenthcentury British society. From the specific context of her lived experience in Patagonia, she presents her readers with a model of Welsh womanhood empowered by greater social equality and more forthright in defence of the Welsh language than her counterpart in the homeland. In 1897, Dr Williams' School Magazine published in its "Old Girls" column a Welsh-language letter from Eluned in which she charges the school's current pupils with the task of boldly standing up for their country and becoming "better Welsh citizens", telling them:

[...] meddech [...] nid oes neb yn disgwyl ichi wneyd dim ond dysgu eich gwersi ac uvuddhau i'ch athrawesau-peidiwch ac ymvoddloni ar hynny

[you might say that ( ... ) no-one expects you to do anything except learn your lessons and obey your teachers-do not be satisfied with that]. ${ }^{34}$

Though less concerned than Gwyneth Vaughan with the suffrage question per se, she too sees women as bound in chains of passive conformity and writes to encourage her readers to cast off such "mind-forged manacles".

\section{The fulfilment of the prophecy}

In their later publications, the two writers followed divergent paths in terms of genre-one becoming a novelist and the other a travel writer-yet there are marked similarities between the core themes which remain dominant in the works of both. Gwyneth Vaughan characteristically published serialized 
journal fictions (two of which were later reproduced as novels) set in rural north Wales, in which the heroines chafe against their gendered limitations. Gwenllian, for example, the young heroine of the series "Bryn Ardudwy a'i Bobl" ("Bryn Ardudwy and Its People", 1903-05), senses future difficulties as she watches her younger brothers on the day of the tailor's annual visit to her home:

[t]aflu i ffwrdd am byth ddillad geneth gyda dirmyg, cael gwared y dillad sy'n caethiwo'r corff, a chael dillad sy'n cyfleu'r syniad o ryddid ac annibyniaeth

[throw(ing) away girls' clothes for ever with contempt, getting rid of clothes that imprison the body, in exchange for clothes that convey the idea of freedom and independence]. ${ }^{35}$

Desperate to change her sex, she chooses to believe one of her father's employees, who tells her that if she spends the night under a bush, she will be a boy when she wakes. Her dream unfulfilled, she redirects her efforts, donning a priest's regalia and conducting her own private service in a local church. The rector, entering the church unnoticed, is so impressed by her heartfelt fluency that, at the end of her sermon, he cannot but join in with his "Amen". They come to an agreement: while the other girls attend their sewing lessons, she will learn Greek and Latin from him, and thus attain an education equivalent to that of her brothers. Nor is she the only female in her community empowered by learning: the older women of Bryn Ardudwy boldly express their views on matters of importance, the uncontested accuracy of their biblical knowledge assuring their status as guardians of the spiritual health of the community.

Similarly, in Gwyneth Vaughan's first published novel, O Gorlannau y Defaid (From the Sheepfold, 1905), a historical fiction set at the time of the 1859 Welsh religious revival, Begi Shon, a lowly candlewick maker, through her Nonconformist zeal, saves the souls of her neighbours by timely interventions. Edward Evans is on his deathbed when she tells him that his regular attendance at Anglican rites will not in itself be enough to save him: an act of kindness to his servant Twm, grieving by his bedside, would be far more likely to ease his path to heaven. Filled with alarm, Edward questions her assurance: how can she be more knowledgeable in such matters than Mr Brown the parson? But her vigorous spirituality and perseverance finally convince him, and he dies enlightened. Another of Begi's formidable neighbours in Bro Dawel, Gras y Tyrpeg (Turnpike Grace), has left her chapel in anger following its expulsion of her weaker brother Benja, who was led astray one night by a gang of local drunkards. As the chapel elders approach the Turnpike, hoping to entice Gras back to the fold, they find her awaiting them in resistant pose:

[...] wedi torchi ei llewys yn uwch na'i phenelin, ei dyrnau cauedig yn gorffwys ar ben bob clun, yn debycach i hen gawres o wlad y Mabinogi [i.e. Welsh medieval tales] nag i hen wraig yn byw yn y bedwaredd ganrif ar bymtheg 
[sleeves rolled up above her elbows, her closed fists resting on each knee, more like a giantess from the land of the Mabinogi than an old woman living in the nineteenth century]. ${ }^{36}$

According to the local doctor: "[roedd] natur wedi rhoi tro fel chwrligwgen yn y Tyrpeg [...] Gras ddylse Benja fod, a Benja yn Gras [nature had turned like a whirligig at the Turnpike (...) Grace should have been Benja and Benja Grace]". 37 With humour, Gwyneth Vaughan convincingly exposes the sham of sexual stereotypes in her portrayal of a rural environment in which biological sex in no way determines the characters' attributes.

Through her representation of such figures, Gwyneth Vaughan sought to combat the influence of that English middle-class import the "Angel of the House", which was still presented as a female ideal in the work of many male fin-de-siècle Welsh-language writers, for all its inappropriateness in terms of the social class of the vast majority of Welsh women. During the second half of the nineteenth century, however, as the power of the squirearchy weakened, the increased availability of higher education saw the rise of many young Welsh males from the lower classes into positions of social leadership, often as Nonconformist preachers or Liberal Members of Parliament. Gwyneth Vaughan's heroines frequently rail against their exclusion from such ranks. Angharad Fychan, the heroine of O Gorlannau $y$ Defaid, fulminates against the Methodists'-in her view-ridiculous adherence to a 2000-year-old pronouncement by the Apostle Paul against women preachers, which continues to debar her from what would otherwise be her chosen profession. ${ }^{38}$ And in Vaughan's election novel, Plant y Gorthrwm (The Children of the Oppression, 1908), set at the time of the 1868 general election, Rhiannon Gruffydd, who is committed to the Liberal cause, realizes that:

Taswn i'n fachgen mi fase rhyw siawns i mi [...] fyn'd yn Aelod Seneddol fy hun $[. .$.$] ond dydw i da i ddim fel hyn$

[If I were a boy, I might have some chance (...) of becoming a Member of Parliament myself (...) but I'm good for nothing like this]. ${ }^{39}$

In a conversation between Rhiannon and her Llangynan neighbour Dyddgu, the 10-year-old local miller's daughter, Gwyneth Vaughan uses the child's viewpoint to highlight the injustices of the electoral system:

"Ydach chi'n mynd i’r lecsiwn fory, Miss Rhiannon?"

"Nag ydw i. Beth 'na i yno, Dyddgu? Fedra i ddim fotio i neb?"

"Pam Miss Rhiannon?"

"Fydd merched ddim yn fotio i neb."

"Pwy sy'n rhwystro chi i fotio? Chi a merched pob man?" [...]

"Wel, y dynion, debyg gen i, Dyddgu. Y nhw sy'n deud sut mae popeth i fod." [...] 
"Mae Jerry Jones, Tŷ-nant, ym mynd i fotio, a mae 'nhad yn deud dydi o ddim yn agos yn gall [...] Rydach chi'n reit gall, Miss Rhiannon! [...] Does dim sens fod dyn heb fod yn gall yn fotio, a chitha ddim [...] Heblaw hynny," a tharawodd Dyddgu ei throed ar y llawr, "does gin ddim dyn ddim busnes $\mathrm{i}$ rwystro dim dynes [...] Chyma i ddim o'u lol nhw wedi i mi fynd yn fawr.”

["Are you going to the election tomorrow, Miss Rhiannon?"

"No, what would I do there, Dyddgu? I can't vote for anyone?"

"Why not Miss Rhiannon?"

"Women don't vote for anyone."

"Who's stopping you from voting? You and women everywhere?" ( ... )

"Well, the men, I suppose, Dyddgu. They're the ones who decide how everything should be." ( ... )

"Jerry Jones, Tŷ-nant, is going to vote, and my father says he isn't half wise (...) You're pretty wise, Miss Rhiannon! (...) There's no sense in a man who's not wise voting and you not (...) Apart from that," and Dyddgu stamped her foot on the ground, "no man has any business preventing any woman ( ... ) I won't take any of their nonsense when I've grown up."] ${ }^{40}$

In the event, the women of Llangynan prove pivotal in the election, for all their disenfranchisement. Rhiannon succeeds in persuading one of the local landlords to vote Liberal, against the general expectation, and his tenants are glad to follow suit. Dyddgu, through her quick-wittedness, saves Liberal voters from being stoned on their way to the poll by the Tory agent's hired gang, and another of Rhiannon's protégées, Elin Tyn'ffordd, takes anarchic direct action, taunting the Tories with ribald rhymes and instigating a number of minor "accidents" which prevent them from casting their vote. ${ }^{41}$ Although the main concern of the novel is to record in fiction the injustices prevalent before the introduction of the secret ballot, when many Liberal tenants of Tory landlords were evicted for exerting their democratic rights, it also makes a spirited case for the enfranchisement of women.

Following her death in 1910, tributes to Gwyneth Vaughan appeared in the Welsh, English and Irish presses confirming an earlier tribute in Y Brython, where she was hailed as

[...] ddynes anghyffredin, ầi hymroddiad di-dor ymhlaid ei rhyw ac ymhlaid llenyddiaeth a gwleidyddiaeth y Dywysogaeth, yn haeddu cydnabyddiaeth gyhoeddus Cymru gyfan

[an extraordinary woman whose tireless commitment to her own sex and to the literature and politics of the Principality merits the public acknowledgment of the whole of Wales]. ${ }^{42}$

One reader who frequently acknowledged her indebtedness to Vaughan was Eluned Morgan, who praises her "gwelediad eglur-iach i guddiad cryfder y Genedl fechan fynodd fyw drwy bob gorthrwm [clear-headed vision into the secret of the strength of the small Nation which insisted on surviving through 
every oppression]". ${ }^{43}$ Survival strength, as a necessity for women as much as men, is also a core value in Eluned's own writings, in many of which she explores the ways in which the individual and social capacity to resist physical or spiritual destruction is either nourished or eroded. A neo-Romantic, like many Welsh-language authors of her generation, she sees in nature, even-or rather especially - at its most threatening, a nourishing resource. The greater the danger, the greater the strength of spirit roused to resist it, and therefore the more empowering the experience. In one striking passage from the second of her travel books, Gwymon y Môr (Seaweed, 1909), she describes how, when a storm at sea threatened the ship on which she was crossing the Atlantic and its captain ordered the passengers below deck, "yr oedd fy nghalon yn llawn gwrthryfel [...] Yr oedd arnaf eisiau gweld y storm [my heart was full of rebellion (...) I wanted to see the storm]". The only safe way to do so, according to the captain, was to allow herself to be firmly bound, like Ulysses, to the ship's mast. From that position, she spent the duration of the storm watching the lightning dance across mountainous waves, and described the experience as "bedair awr o wynfyd adawodd ei ôl ar fy holl fywyd [four hours of bliss which left their trace on my whole life]".

Other vital sources of nourishment were silence and solitude; influenced no doubt by her reading of Thoreau's Walden, ${ }^{45}$ she insisted in her first book, Dringo'r Andes (Climbing the Andes, 1904), that: "Mae'n rhaid i bob enaid cryf wrth dawelwch ac unigedd i wynebu ei fywyd [...] i ddwysfyfyrio ac i gasglu nerth ysbrydol [Every strong soul must have silence and solitude to face its life (...) to meditate and collect spiritual strength]". ${ }^{46}$ That the conditions of modern civilization, with its crowded cities and busy tumult, eroded such strength is a constant complaint throughout her work. In the rainforests of Brazil, for example, while marvelling at the fact that the forests which surround her stretch for hundreds of miles without a break, she mourns that so few have the opportunity to experience them:

O! na fyddai modd $i$ ieuenctid ein dinasoedd mawrion gael eu gollwng yn rhydd am ychydig wythnosau i goedwigoedd fel hyn, ac yn y distawrwydd a'r mawredd ofnadwy i ddeall unwaith am byth beth yw bywyd mewn gwirionedd [...] Ond erbyn heddiw, nid oes ond ambell fangre fel hon nad yw llaw halog dynoliaeth syrthiedig wedi ei hanurddo a'i llychwino. Mae'r golled a'r trueni o'r cyfan yn dod adre' gyda grym ysgubol weithiau, ac yn ysgwyd eneidiau i'w sylfeini, ac "wele gwnaethpwyd pob peth o'r newydd", ac aeth bywyd a'i holl gysylltiadau yn gysegredig a sanctaidd fyth mwy.

[O! that it were not possible for the youth of our large cities to be released for a few weeks to forests like this, and in the silence and terrible majesty understand once and for all what life truly is (...) But by today there are but a few places like this which the polluted hand of fallen man has not desecrated and fouled. The loss and pity of it all comes home with sweeping force sometimes, and shakes souls to their foundations, and "behold, all things are become new", and life and all its associations become holy and sacred evermore]. ${ }^{47}$ 
In this complex passage, the very intensity of her frustration that such green oases should be despoiled is recognized in the last half-sentence as in itself a saving grace; the suggestion is that such a degree of passionate pity could not be experienced were it not that the human psyche does, after all, somewhere secrete the energy to resist its own self-destruction.

The image Eluned projects of herself in such passages is by no means conventionally feminine: she is Ulysses tied to the mast, seduced not by sirens but storms; she is the lone explorer in the wilds. But she consistently attributes her adventurous spirit not to any singularity of her own, but to her Patagonian upbringing, and is particularly eager to advocate that the Welsh women of the motherland should also adopt such fearlessness. Fear she presents as in itself the greatest of those corrosive blights which threaten survival; in $\mathrm{Ar}$ Dir a Môr (On Land and Sea, 1913), she interrupts an account of a visit to Palestine with a tirade against fear: "Mae gormod o ofn yn y byd o lawer [...] ac ni fedrais erioed ddygymod âg ef [There is far too much fear in the world (...) and I never could put up with it]". She addresses herself specifically to her female readers, asking them not to permit fear a place in their homes:

Byddaf yn dychmygu gweld yr angylion yn wylo wrth glywed ambell i fam yn dysgu ei phlentyn bach i ofni cyn ei ddysgu i siarad [...] Nid yw ufudd-dod drwy ofn yn werth dim

[I imagine seeing the angels weep on hearing some mother teaching her little child to fear before she teaches it to speak (...) Obedience through fear is worth nothing]. ${ }^{48}$

Fear induces a degenerate conformity which, for her, is anathema. She protests:

Mae cymaint o ddynion da yn mygu'r dyfnderau bron ar hyd eu hoes, ac yn cyd-ymffurfio a llawer o bethau a ddirmygant yn llwyr yn y dyfnderau hynny [...] rwyf yn methu'n lan a dygymod munud a chwarter modfedd o gydymffurfio

[So many good people stifle the depths throughout their lives almost, and conform with many things which they despise totally within those depths (...) I simply cannot tolerate for a minute a quarter inch of conformity]. ${ }^{49}$

By such admonishments, Eluned sought to awaken in her female readers in particular latent strengths repressed by both their gendered and ethnic social conditioning. In 1909, in a public address on patriotism, she had "Mae gennyf neges arbennig at ferched Cymru y dyddiau hyn [A special message for Welsh women of these days]". For the sake of their nation's survival as well as their own, they must resist the politics of fear and the degenerate servility it induces, for:

Nid oes dim y mae John Bull yn ei ddirmygu fwy na gwaseidd-dra, a gwaseiddiwr fu'r Cymro ar hyd y blynyddoedd, ond y mae'n deffro'n raddol 
[There is nothing John Bull despises more than servility, and the Welsh have been servile throughout the years, but they are awakening slowly]. ${ }^{50}$

Welsh women are here called upon to manifest their latent strength and strike a blow for women and for Wales.

What Gwyneth Vaughan and Eluned Morgan shared, then, was an ideology in which the maxims of Cymru Fydd were closely interlinked with the call for greater female self-reliance and independence. Their literary contemporaries within the women's movement in Wales-writers like Cranogwen and Ellen Hughes-did not emphasize the intersectional (gendered and ethnic) nature of the struggle to the same degree. Both Vaughan and Eluned also functioned as progressive role models for their sex in terms of the manner in which they lived their lives, as well as in their writings: both took up leadership roles, ascending to public platforms to promote their ideas. It was no doubt in recognition of their promise as political agents who could feminize the discourses of Welsh independence that both, in 1898, were duly given starring roles in Dafydd Dafis's dream vision of the emancipation of Welsh women.

\section{Notes}

1. Mrs Wynford Philipps, "Notes on the Work of Welsh Liberal Women", Young Wales, 1 (1895): 17-19 (18). Nora Philipps, the wife of the Liberal Member of Parliament for Pembrokeshire, was the founder and first president of the Welsh Union of Women's Liberal Associations and the founder of the Women's Institute.

2. [J. Hugh Edwards], "Notes on the Work of Welsh Liberal Women", 19.

3. Nora and Elsbeth Philipps, "The Progress of Women in Wales", Young Wales, 2 (1896): 65-67 (67).

4. Ursula Masson, “Hand in Hand with Women, Forward We Will Go': Welsh Nationalism and Feminism in the 1890s", Women's History Review, 12.3 (2003): 357-86 (374).

5. Michael D. Jones, Y Ddraig Goch, 15 Nov. 1862: 3; qtd. in translation in Dafydd Tudur, "The Life, Thought and Work of Michael Daniel Jones (1822-1898)", PhD thesis, U of Wales, Bangor, 2006, pp. 223-24.

6. Glyn Williams, The Welsh in Patagonia: The State and the Ethnic Community (Cardiff: U of Wales P, 1991), p. 40.

7. Williams, Welsh, p. 40, referencing manuscript records of the Settlement Council, held in the Museo Regional de Gaiman. See also R. Bryn Williams, Gwladfa Patagonia/The Welsh Colony in Patagonia 1865-1965 (Cardiff: U of Wales P, 1965), p. 43: "The members of the senate were elected annually, and everyone over eighteen had a right to vote by ballot. Fifty years were to pass before women gained the right to vote in Great Britain". But see also Carnarvon and Denbigh Herald, 23 July 1897: 5, where Lewis Jones states categorically of the Welsh settlement's constitution: "Up to the present a woman has no vote" (we are indebted to E. Wyn James for this reference). It is not impossible that both statements are correct-i.e. that it was the initial intention of the Settlement Council to enfranchise women but that, in the event, given the very difficult circumstances in which the settlers found themselves on their 
arrival in Patagonia, and the interventions of the Argentinian state in their governance, that aim was never fully put into practice.

8. Reports of the Commissioners of Inquiry into the State of Education in Wales (London: HMSO, 1847), pt. 2, p. 60.

9. For a further account of the Association's aims and achievements, see W. Gareth Evans, Education and Female Emancipation: The Welsh Experience 1847-1914 (Cardiff: U of Wales P, 1990), pp. 110-253.

10. Masson, "Hand”", 373-74.

11. Beriah Gwynfe Evans, Dafydd Dafis, sef Hunangofiant Ymgeisydd Seneddol (Wrexham: Hughes a'i Fab, 1898), p. 313.

12. For the argument that Dafydd Dafis's "vision" encodes male anxieties with regard to the growth of the women's movement, see M. Wynn Thomas, The Nations of Wales 1890-1914 (Cardiff: U of Wales P, 2016), pp. 59-61.

13. For an explanatory note on the nine historical figures portrayed in Ab Caledfryn's cartoon, see Ursula Masson, "Women's Rights and Womanly Duties": The Aberdare Women's Liberal Association, 1891-1910 (Cardiff: South Wales Record Soc., 2005), pp. 237-38.

14. For further material on Cranogwen, see Jane Aaron, "Gender Difference Is Nothing': Cranogwen and Victorian Wales”, Queer Wales: The History, Culture and Politics of Queer Life in Wales, ed. Huw Osborne (Cardiff: U of Wales P, 2016), pp. 29-44. For further reference to Ellen Hughes, see Kirsti Bohata, "Bertha Thomas: The New Woman and 'Anglo-Welsh' Hybridity", New Woman Hybridities: Femininity, Feminism and International Consumer Culture, 1880-1930, ed. Ann Heilmann and Margaret Beetham (London: Routledge, 2004), pp. 17-34 (17) and Ellen Hughes, "Y Ddynes Newydd [The New Woman]", Y Gymraes, 1 (1896-97): 28-29.

15. Ryland Wallace, The Women's Suffrage Movement in Wales 1866-1928 (Cardiff: U of Wales P, 2009), p. 38. For further discussion of Gwyneth Vaughan's life and work, see Rosanne Reeves, Dwy Gymraes, Dwy Gymru: Hanes Bywyd a Gwaith Gwyneth Vaughan a Sara Maria Saunders (Cardiff: Gwasg Prifysgol Cymru, 2014).

16. “Temperance Meeting at Merthyr", Merthyr Times, 19 May 1893.

17. Gwyneth Vaughan, “The Ladies Column”, Welsh Weekly, 20 May 1892: 7.

18. Gwyneth Vaughan, “Colofn y Merched”, Yr Eryr, 21 Nov. 1894: 8.

19. Masson, "Hand", 361. For a full account of Welsh women in Liberal politics during this period, see Ursula Masson, For Women, for Wales, and for Liberalism: Women in Liberal Politics in Wales 1880-1914 (Cardiff: U of Wales P, 2010).

20. Gwyneth Vaughan, "Woman and Their Questions", Young Wales, 3 (1897): 19-20.

21. Vaughan, "Woman", 20.

22. Floya Anthias and Nira Yuval-Davis, "Contextualizing Feminism: Gender, Ethnic and Class Divisions”, Feminist Review, 15 (1983): 62-75 (62).

23. Angelia R. Wilson, introduction, Situating Intersectionality: Politics, Policy and Power, ed. Wilson (New York: Palgrave, 2013), pp. 1-10 (3); the term "intersectionality" was coined by Kimberlé Crenshaw in her article "Mapping the Margins: Intersectionality, Identity Politics, and Violence against Women of Color", Stanford Law Review, 43.6 (1991): 1241-99.

24. Philipps, "Progress", 65-66.

25. Esther Emment and Eluned Morgan, Traethodau ar Drevnusrwydd Teuluaidd (Y Wladva: Swyddfa'r Dravod, 1892). 
26. R. Bryn Williams, Eluned Morgan: Bywgraffiad a Detholiad ([Llandysul]: Y Clwb Llyfrau Cymreig, 1948), pp. 10, 12.

27. Chris Moss, Patagonia: A Cultural History (Oxford: Signal, 2008), p. 133.

28. Williams, Welsh, p. 41.

29. Eluned Morgan to William George, Trelew, Patagonia, Apr. 1900; W. R. P. George, ed., "Gyfaill Hoff ... ": Detholiad o Lythyrau Eluned Morgan (Llandysul: Gwasg Gomer, 1972), p. 62.

30. Eluned Morgan to William George, Whitsun 1899; George, p. 54.

31. See Eirian Wyn Lewis, "Eluned Morgan 1870-1938: Llenor y Wladfa", Trafodion Cymdeithas Hanes y Bedyddwyr, 2014-15: 1-28.

32. Eluned Morgan, "Y Wladfa Gymreig", Cymru, 12 (1897): 12-16 (14).

33. Eluned Morgan, "Ysgol Ddyddiol yn y Wladfa Gymreig", Heddyw, 1 (1897): 100; the text italicizes.

34. Eluned Morgan, "Contributions from 'Old Girls”, Dr Williams' School Magazine, 1 (1897): 11-13.

35. Gwyneth Vaughan, "Bryn Ardudwy a'i Bobl”, Yr Haul, 5.59 (1903): 518; infant boys were, like girls, dressed in frocks during this period.

36. Gwyneth Vaughan, O Gorlannau y Defaid (Carmarthen: W. Spurrel a'i Fab, 1905), p. 37. The novel was first published as a weekly series in Y Cymro (1903-05).

37. Vaughan, O Gorlannau, p. 42.

38. Vaughan, O Gorlannau, pp. 163-64.

39. Gwyneth Vaughan, Plant y Gorthrwm (1908; Dinas Powys: Honno, 2014), p. 66. The novel was first published as a weekly series in Y Cymro (1905-06).

40. Vaughan, Plant, pp. 171-72.

41. For the suggestion that Elin, with her subversive lack of inhibition, represents Rhiannon's alter ego, see Katie Gramich, Twentieth Century Women's Writing in Wales (Cardiff: U of Wales P, 2007), p. 33.

42. Y Brython, 21 May 1908.

43. Eluned Morgan to William George, 1 Sept. 1905; George, p. 110.

44. Eluned Morgan, Gwymon y Môr (1909); rpt. in Ceridwen Lloyd-Morgan and Kathryn Hughes, eds., Dringo'r Andes a Gwymon y Môr (Dinas Powys: Honno, 2001), pp. 100-01.

45. For her appreciation of Walden, see Eluned Morgan to William George, April 1900; George, p. 61: "Ni ddarllenais lyfr mor iach, a chymaint o awel y mynydd ynddo er's llawer ddydd [I have not read so healthy a book, with so much of the mountain breeze in it for many a day]".

46. Eluned Morgan, Dringo'r Andes (1904); rpt. in Lloyd-Morgan and Hughes, p. 15.

47. Lloyd-Morgan and Hughes, pp. 128-29. The quote is from 2 Cor. 5.17.

48. Eluned Morgan, Ar Dir a Môr (Abergavenny: Y Brodyr Owen, 1913), pp. 6566.

49. Eluned Morgan to D. R. Daniel, 10 Apr. 1916; George, pp. 207-08.

50. Eluned Morgan, 1909; qtd. in Williams, Eluned Morgan, p. 11.

\section{Disclosure statement}

No potential conflict of interest was reported by the authors. 


\section{Index}

\section{A Dir a Môr 141}

Aaron, Jane 40-41, 55, 83-4, 96, 107, 115, 120

ab Bran, Helfin ferch Garadawc 13

ab Caledfryn 131, 134

ab Ieuan, Alis ferch Gryffudd 10-13, 19

ab Ieuan, Gryffudd 10

Acts of Union (1536-43) 3-4, 14-15, 64

adapting the Risorgimento 78-93

"adventure" schools 65-6

Aikin, Lucy 44

Aled, Tudur 10, 14

alienation $56-8,87$

Alsen, Iarless 98

altruism 82

always "local and contemporary" 57-60

American Civil War 49

"An Elegy on Neest" 35

anachronism 102

Anglicanism 65, 73, 75, 80, 89

Anglophone women poets 30-47

"Ann of Kidwelly" 51, 55-6

"Ann of Swansea" 5, 48-62; see also Hatton, Ann Julia

Ann-of Swansea? 55-7

anonymity $11-12,55,68$

antagonism 78, 86

Anthias, Floya 134

antiquarian Romantics 30-47

argument of Artegall 69-72

Artegall 63-77; the argument 69-72; the cartoon 72-6

Arthur, Gwen 13

Arthurian past 34-5

Association for Promoting the Education of Girls in Wales 130

Athenaeum 70-71, 80

attribution problems $10-29$

autocracy 84

Baillie, Joanne 96

Baker, Elizabeth 44 bardic circles see poetic circles

Bardic Nationalism 96

"Bards of Old" 30-31

"The Bard" 5

Barrett Browning, Elizabeth 54

Batridd, Ben 41

Battle of Bosworth 103-4

Beale, Anne 7, 113-14, 119-20

Beauties of Wales 97

Behrendt, Stephen 2

Beirdd Ceridwen 12

bicultural protagonists $86-90$

bigamy 49

Blodeu-gerdd Cymry 19

Bluog, Gerddi 13, 15

Blwch y Cantorion 19

Boadicea 31

bonheddwyr 80-81, 84, 87

Book of Common Prayer 13

"Brad y Llyfrau Gleision" 63, 97

Brennan, Catherine 56

"Breosa" 58

Brereton, Jane 23, 32-4, 39, 44

British Historical Fiction Before Scott 96

"British Liberty" 70

British Women's Temperance Association 131-2

Britishness 84-6

Briwtwn, Siân 23

"Bryn Ardudwy a’i Bobl" 137

"Bryn Ardudwy and its People" 137

A Burglary 123

Burns, Robert 59

BWTA see British Women's Temperance Association

Cadwaladr, Huw 16

Cambrian bards 30-47

Cambrian Journal 79

Cambrian Pictures; or, Every One has Errors 51-2, 56 
The Cambrian 51, 59

careers are born 132-6

caregiving 120

cartoon of "Artegall" 72-6

Castle Rackrent 85-6

casual anglocentricity 2

Cell Callestr 19

Cell of Flint 19

Celtic Revival 3-5, 16

Celticism 34-5

Ceridwen's Poets 12

Charnell-White, Cathryn 4

Chartism 64

Chaucer, Geoffrey 32-4

Chedgzoy, Kate 2

Children of the Oppression 139

Chloe Arguelle 115

"Christ's Suffering" 20

Chronicles of an Illustrious House 55

Church of England 65, 73, 89

civil unrest 64-6

Civil War 5

Clare, John 59

Clarke, Gillian 1

Climbing the Andes 140

Coal Mines Act 1842112

Collins, Willkie 106

commonality of feeling 52-3

community 48-62

conformity 141

constitutional monarchy $80-81$

constructing a female canon 11-13

Corinne, or Italy 101, 103

Corn Laws 5-6

Country Landlords 6-7, 78-93

Cranogwen 132, 142

critical regionalism 88

Cromwell, Thomas 4, 65

cross-dressing 101

Curtis, C. 49

Cymmrodorion 5

Cymru 135-6

Cymru Fydd movement 7, 94, 128-30, $133-4,142$

Cymry Cymraeg 90

cynghanedd 14, 16, 22

"Cywydd y gont" 21

cywyddau 14, 16, 20-21, 24

Dafis, Dafydd 131, 142

Dafydd Dafis 130-32

Dafydd, Marged 13, 16-17, 20, 22-3

"Dafydd y Garreg Wen" 38

Dainotto, Roberto M. 83, 88

Darwell, Mary 44

"Dau Wynne" 113
Daughters of Rebecca 64

"David of the White Rock" 38

Davies, John 22

Davis, Richard Bingham 50

de Groot, Jerome 96

de Staël, Madame 101, 103

Dearnley, Moira 40-41

democratic idealism 85

devolution 1-9

Devolution Referendum 1997129

Dickens, Charles 108

Dillwyn, Amy 7, 59, 113-15, 123-4

"Dioddefaint Crist" 20

"A Dirge to the Memory of Thomas

Chatterton" 43

disability $121-3$

disenchantment 87

displaced heroes 86-90

displacement 51-2

dispossession 56, 104-5

Don Quixote 100-102

"Doom of the Griffiths" 95, 97, 104-5

Dr Williams' School Magazine 136

"The Dream" 32-3

Dringo'r Andes 140

Druids 1, 35, 40-42, 44-5

Dyer, John 31

Edgeworth, Maria 85-6

Edwardian women's prose 5-8

eighteenth-century Welsh poets $30-47$

electro-sexual therapy 49

Elegiac Sonnets and Other Poems 53

Eliot, George 111

Ellis, Rees 17

Ellis, Thomas E. 128

emancipation of Welsh women 128-44; early literary careers 132-6; fulfilment of prophecy 136-42

"Emancipation of Women" 131-2

The Emigrants 52

Emmeline: or, The Orphan of the Castle 55

Engan, Elen 132

English viewpoint 63-4, 81-4

The English Historical Novel 96

englyn form 14-15, 17-18

"Epistle to Mrs Anne Griffith" 32

Equal Franchise Bill 129

erotic poetry $19,21,48-9$

Evance, Susan 54-5

Evans, D. Gareth 7

Evans, Evan 5, 34-6, 42-3

"Evening Address to the Seagull" 54

Fach, Dolwar 20

Faerie Queene 68-9 
Felix Holt 111

female bards 3-5

feminization 100

feudalism 102-3

First World War 3, 7, 112-13

Flaidd, Gwenllian ferch Rhirid 11-12, 14-15, 19

Fleishman, Avrom 96

"For Women, for Wales and for Liberalism" 7

"The Foster Child" 40

Fraternity 114-15

fratricide 104

free-metre poetry $16-18$

French Revolution 5, 49-50, 101-2

Freudian paradigm 105

From the Sheepfold 137

Fugitive Pieces 43

fulfilment of prophecy 136-42

Fychan, Elsbeth 15, 17

Fychan, Gwerful 13-15

Fychan, Jane 16-17

Gallagher, Catherine 111-12

Gaskell, Elizabeth 95-8, 104-8, 111

Gemeinschaft 81

gender parity 1-9; female bards 3-5;

Victorian/Edwardian Wales 5-8

George, David Lloyd 128, 135

George, William 134

Gerald Fitzgerald; An Irish Tale 51

Gesellchaft 81

Gethin, Barbara 13

Gethin, Ieuan 21

Gladys of Harlech 7, 79-81, 95, 98-9, 102-4, 108

Glyndŵr, Owain 3, 7, 94-5, 97-8, 105

Goch, Elor 12-13

Gorawen Meirion 19

government report on education (1846-

1847) 6, 63-77, 79-80, 97, 129; see also

Williams, Jane

Graham, Dr James 49

Grave, Mabel Holland 114-15

Gray, Kathryn 48-9

Gray, Thomas 5, 43, 68

Griffiths, Ann 1-2, 18, 20

Guardian newspaper 1

Guest, Harriet 49, 52-4, 57

Gwenddydd chwaer Myrddin 13

gwerin 80-90

Gwymon y Môr 140

Gwyneddigion 5

Gwynfe Evans, Beriah 130

Hael, Gwladus 12-13, 15, 21

Hall, Augusta 6, 67-8, 75, 87 halsing 13

Harding Davis, Rebecca 112

harp-playing 36-9

Harri, Marged 23-5

Hatton, Ann Julia 5, 48-62; always "local and contemporary" 57-60; Ann-of Swansea? 55-7; London-New YorkSwansea 49-51; Poetic Trifles 51-4

Hatton, William 50-51

Haycock, Marged 15

Headley, Henry 43-4

Hearts of Wales: An Old Romance 7, 94-5, $98,106-7$

heavy industry see industrial fiction (1880-1910)

Heddyw 136

Hemans, Felicia 2-3, 5, 7, 44-5

Hên Ganiadau Cyymu 38-9

Henry IV, Part I 94

Henry VII 95, 99

Henry VIII 3-4, 14-15, 64

heroinism 101, 108

heroism 94-110

Hir, Ieuan Brydydd 5

hiraeth 40

historical fictions 94-110

History of British Women's Writing 2

The Historical Novel 96

The Historical Novel in Europe 96

Hodgson Burnett, Frances 112

"Hoel's Harp" 56

Home Rule movement 7, 97, 107, 128, 133

Honno Press 2, 11

House of Fame 32-3

Hughes, Anne 5, 16, 36-7, 39-40, 44

Hughes, Ellen 132, 142

Hughes, Hugh 72-4, 76

Hughes, John Ceiriog 38

Humphreys, Robert 16

hymn-singing 113

ideas of liberal nationhood 78-93

"illogical and unfair" 63-77

immurement 106

imperialism 89

industrial fiction (1880-1910) 111-27

instructional tales 120

Intermediate Education Act 1889130

internal colonialism 89

intersectionality 134,142

"Invocation to Melancholy" 43-4

itinerant life of Hatton 49-51

Ivanhoe 103-4

Jack and Jill 123

Jacobite rebellion 98 
James, Angharad 12, 16-20, 23

James, Christine 1

Jane Rutherford 112

Jemima 37

Jenkins, Geraint H. 89

Jenkins, Philip 119

Jenkins, Rachel 134

Jewsbury, Endsor 80

John Bull 141-412

"John Williams" 42

Johnston, Dafydd 14-16

Jones, Dafydd 18-20, 22

Jones, Edward 38-40

Jones, Evan 73-4

Jones, Florence 12, 17

Jones, Jane 59

Jones, Michael D. 129

Jones, Nansi 18

Jones, Rice 23

Joy of Meirionethshire 19

Keating, Joseph 114, 120-21, 124

Kemble, John Philip 49-50, 58

Kemble Street 59

kidnapped heroines 86-90

Klaus, H. Gustav 115, 118

Knight, Stephen 112, 120

Knowles, Claire 54

"Lamentation of Llwarch-hen, the Bard" $42-3$

Landon, Letitia 54, 59

Langford, Richard 16

Las, Siôn Dafydd 14

"Last Words of Cadwallon" 38-9

Lay of the Irish Harp 52, 56

Leapor, Mary 57-8

Lee, Sophia 102

"Lewellin and His Bards" 44

"Lewin and Gynneth" 40-42

Lewis, Gwyneth 1

liberal nationhood 78-93

Life in the Iron Mills 112

liminality 55, 66-9; see also Williams, Jane linguistic purity $70-71$

Llangollen Vale 44

llatai rubric 23-4

Lloyd-Morgan, Ceridwen 14

Llywd, Dafydd 15, 21

Llywelyn ap Gruffudd 3

"Llywelyn a Gwrneth" 40-42

"local and contemporary" 48-62

local governance 84-6

Local Government Act 1894133

loco-specific description 32-4

London Chronicle 40 love of country 96-7

"love messenger" rubric 23-4

Lukács, Georg 95, 100

mab darogan 3

Macbeth 104

Macpherson, James 5

Madryn, Catrin 13, 23

A Maid of Cymru 113, 115-18

Malen, Mary 14

Mary Barton 111

masculinization 100

Massey, Doreen 88

Masson, Ursula 7

Maxwell, Richard 96

Mayne, Fanny 112

Mazzini, Giuseppe 6-7, 85

Mechain, Gwerful 12-14, 18-22

Meistres Bankes 13

melodrama 117

Merlin 31-2

Merthyr Times 132

Merthyr Uprising 6, 64

Methodism 12-13

Methodist Revival 5

middle-class perceptions 90

Milne, Anne 57-8

The Miners' Strike 112

Minerva Press 51, 59-60

misogyny $21-2$

Mitchell, David 120, 122

mock melancholy 54

mockery 63, 65, 72-6

Monody on Major André 50, 52

Moore-Colyer, R. J. 82

Morgan, Eluned 128-44

Morganwyg, Iolo 31

Morning Chronicle 64

Morning Post 54

Morris, Lewis 16

Murray, Lindley 68-9

Musical and Poetical Relicks 38-9

Myddleton, Mary 32

"Nant Olchfa" 123

narrating liberalism 81-4

national confidence 84

National Eisteddfod 1

national identity $94-110$

nationalism $52-3$

The Never Never 48

Newman, A. K. 51

Newport Rising 64

Nonconformism 11, 65, 73, 79, 119, 137-8

"Norman yoke" 102-4

North and South 111 
"Nova Scotia" 52

novel in search of ideal 84-6

O Gorlannau y Defaid 137-8

Ode on the Peace 50

Oedipal-Gothic curse 105

Oedipus myth 105, 108

Oedipus Tyrannus 105

"Of the Welsh Pennillion" 39

Offa's Dyke 3, 68

Ollivant, Alfred 89

On Land and Sea 141

"On the Welch Language" 30

"Orinda" 2; see also Philips, Katherine

"Ossian" fragments 5, 42

othering 89

"our poor land of Wales" 94-110

Owen, Catherin 15

Owen, David 38

Owen, Ifan Tudur 15

Owen Tudor: An Historical Romance 95, 99-102

Owenson, Sydney 52-3, 56

Oxoniensis 42-3

Parry, Jonathan 82

Parry, Lowri 17-18, 36

Patagonia 128-44

paternalism 88

patriarchy $7,11,21,37,95,103-6$

patriotism 97

Peace of Paris 50

Penllyn, Tudur 14-15

Penn, Thomas 99

Penny, Anne 5, 16, 35-7, 39-40, 42-4

philanthropy 82

Philipps, Janetta 44

Philipps, Nora 128-31, 134

Philips, Katherine 2-3, 5, 30-32, 36, 44

Pictures for the Millions of Wales 72-3

Pittock, Murray 57

Plant y Gorthrw 138

Plath, Sylvia 54

Plymouth Brethren 75

poaching 115-17, 123; salmon 115-16

Poems. By Mrs Hughes 36-7

Poems, with a Dramatic Entertainment 35

Poems, Lyric and Pastoral 31

Poems on Miscellaneous Subjects 48, 50,52

Poems and Other Pieces 43

Poet Laureate 48

poetic circles $20-25$

poetic foremothers 25

Poetic Trifles 5, 48-9, 51-3, 56, 59-60; see also Hatton, Ann Julia poetry of "Ann of Swansea" 48-62; see also Hatton, Ann Julia

political enfranchisement 128-9

Poor Relief 65-6

popular fiction 51

Porter, Jane 96, 100, 104

positionality in community $52-3$

Powell, Nia 14, 16

Prescott, Sarah 5

Price, Elisabeth 13

Price, Fiona 96, 100

Prichard, Michael 22-3

Prince of Wales 3

Principality 79

problems of authorship; free-metre poetry 16-18; poetic circles $20-25$; (re)

constructing a female canon 11-13;

strict-metre poetry 14-16; synchronic

reality of female tradition $18-20$

prohibition on speech 106

prostitution 49-50

Protestant Reformation 17

provinciality 58

Prys, Edmwnd 15, 24-5

psychoanalytic reading 105

Puddicombe, Anne Adaliza, see Raine, Allen

Pugh, Jane 17

Queen o' the May 113, 118-20

querelle des femmes 12

Radcliffe, Ann 106

Raine, Allen 7, 59, 94-8, 103, 106-8, 113-14, 119-21

Raleigh, John Henry 96

rapprochement 114

The Rebecca Rioter 114, 123

reception 48-62

The Recess 102

reconstructing a female canon 11-13

"Red Book of Hergest" 42

Rees, Sarah jane 132

regicide 104

regionalism $82-3,88$

religious devotion 59

Religious Tract Society 113

Renaissance 13

Report into the State of Education in Wales 63-77, 79-80, 97, 129; see also Artegall;

Williams, Jane

republicanism 86

"Rhydd-freiniad y Ddynes" 131

Richard III 104

"Rights of Man" 101-2

Risorgimento 7, 78-93 
Roberts, Grace 17

Roberts, Kate 2

Robinson, Emma 94-5, 97-103, 108

Robinson, Mary 2, 5, 40-44, 50, 53, 59

Roman Catholic Church 4-5, 65

Rowland, Margaret 19-20, 22-3

Ruins of Rome 31

Russell, John 73

St Winifred 33

Samson, Siân 13

Saunderson, Irene 7, 112, 114-22, 124

scandal 49-51, 59; see also Hatton, Ann Julia

Scotch Cattle 64

Scott, Walter 38-9, 95-6, 100-103

Scottish Chiefs: A Romance 100-101, 104

Seaweed 140

second wave feminism 1-2, 11

self-importance 122

self-portraiture 55

self-publishing 67,76

self-sacrifice 122

sentiment 51-4, 59-60

Seward, Anna 44, 50, 54

Shakespeare, William 94, 98, 104

Shields, Rob 68

Shuttleworth, James 66, 69-70, 73

Siddons, Sarah 49-50, 53, 58

sin-eating 97, 107

Singer's Box 19

smallpox 49

Smith, Charlotte 52-3, 55

Snyder, Sharon 120, 122

social dichotomy 82

social mobility $80-81$

social network of sentiment 51-4

social rights 70

socialism 115

Some Specimens of the Antient Welsh Bards $5,34-5,42$

Son of Judith 114, 120-21, 124

"Sonnet to Love" 52

Sophocles 105

South Wales Daily Post 58

Spenser, Edmund 68

Spooner, Louisa Matilda 6-7, 78-96, 98-9, 103-4, 106; bicultural protagonists

86-90; conclusion 90; narrating

liberalism 81-4; Whigs and Tories 84-6

squirearchy 78-9, 89

Stafford, Fiona 57

Stevens, Anne H. 96

Stewart, Gertrude 131

Stothard, Thomas 53 strict-metre poetry $10,12,14-16$

strike action 114-18, 122

"The Strike Novel in the 1890s" 115

Stuart, Charles Edward 98

subjugation $107-8$

suicide 49,55

superstition 107

"Swansea Bay" 48, 53-4, 56, 58

Swansea and Glamorgan Herald 79

synchronic reality $18-20$

T. S. Eliot prize 49

taeogion 80-81, 84

Tale of Two Cities 108

“Taliesin's Poem to Prince Elphin" 35, 39, 41-5

Tammany, or the Indian Chief 50

"Temple of Hymen" 49

That Lass o' Lowrie's 112

Thomas, Dylan 48, 59

Thomas, Patrick 31

Thomas, Robert 10, 14

Thomson, James 54

"To a Raven" 59

Town and Country Magazine 42-3

tradition of Welsh women writers $18-20$

"Treachery of the Blue Books" 63, 79,97

Tree, Rose 52

Trevnusrwydd Teuluaidd 134

tribalism 85

Trumpener, Kate 96

Tudor, Henry 3-4, 7, 95, 98-9, 102, 104

Tudor, Owen 95, 98-9, 103

ubiquity of industrial accidents 121-4

Union Nationalism 90

Unitarianism 97

Vaughan, Gwyneth 7, 128-44

Vaughan, Robert 15

Vaughan, Roland 16

Vicinus, Martha 111-12

Victorian women's prose 5-8

virtual network of sentiment 51-4

"Votes for Women" 133

Vychan, Ap 14

Walden 140

"Walk on the Sands" 54

Walsingham, or the Pupil of Nature 40

Walters, John 44

Waverley 95-6, 100-102

Welsh Act of Union 3-4

Welsh difference 3-5, 63-4 
"Welsh Drogheda" 65

Welsh language 69-72, 79-80, 84, 87-90, $97,114,129,133-40$

Welsh Manuscript Society 67

Welsh Melodies 5, 44-5

Welsh model village 81-4

Welsh National Assembly 1-2, 129

Welsh suffrage 64, 128-44

Welsh Union of Women's Liberal Associations 133

Welsh Weekly 132

Welsh-language women's canon pre- 1800 10-29

A Welsh Heroine 114, 117-21

A Welsh Singer 113

A Welsh Witch 7, 113-14, 119-20

Welshmen's Anthology 19

Whigs vs Tories 84-6

The Wild Wreath 40

William, Dafydd 20

Williams, Helen Maria 50, 54

Williams, Jane 6, 63-77; Artegall: the argument 69-72; Artegall: the cartoon 72-6; liminality of 66-9

Williams, Mallt 7, 113, 119

Williams, Martha 18

Williams, Raymond 112

Williams, Rebecca 17

Williams, William 64-5

Williams, William Morgan 131

Winter 54
Wollstonecraft, Mary 53, 55, 134

Woman in White 106

Women, Writing and the Industrial Revolution 111

women's historical fiction see historical fictions

women's industrial fiction see industrial fiction (1880-1910)

women's suffrage 128; see also emancipation of Welsh women

Women's Writing in the British Atlantic World 2

Wordsworth, William 59

Wynn Thomas, M. 118-19

Wynn, Williams 37

Y Brython 139

Y Dravod 135

"Y Fflangelliad" 74; see also Artegall

Y Frythones 132

$Y$ Genedl Gymreig 130

Y Traethodydd 1-2, 11, 18

yellow fever 50

ymrysonfardd 21-2

Young Italy movement 85

Young Wales 128-9, 133-4

Yr Eryr 133

Ysgafell 6, 63-77; see also Williams, Jane Yuval-Davis, Nira 134

Zlotnick, Susan 111 